RESEARCH REPORT

\title{
A Cost-Benefit Framework for Analyzing the Economic and Fiscal Impacts of State-Level Immigration Policies
}

Lynn A. Karoly, Francisco Perez-Arce

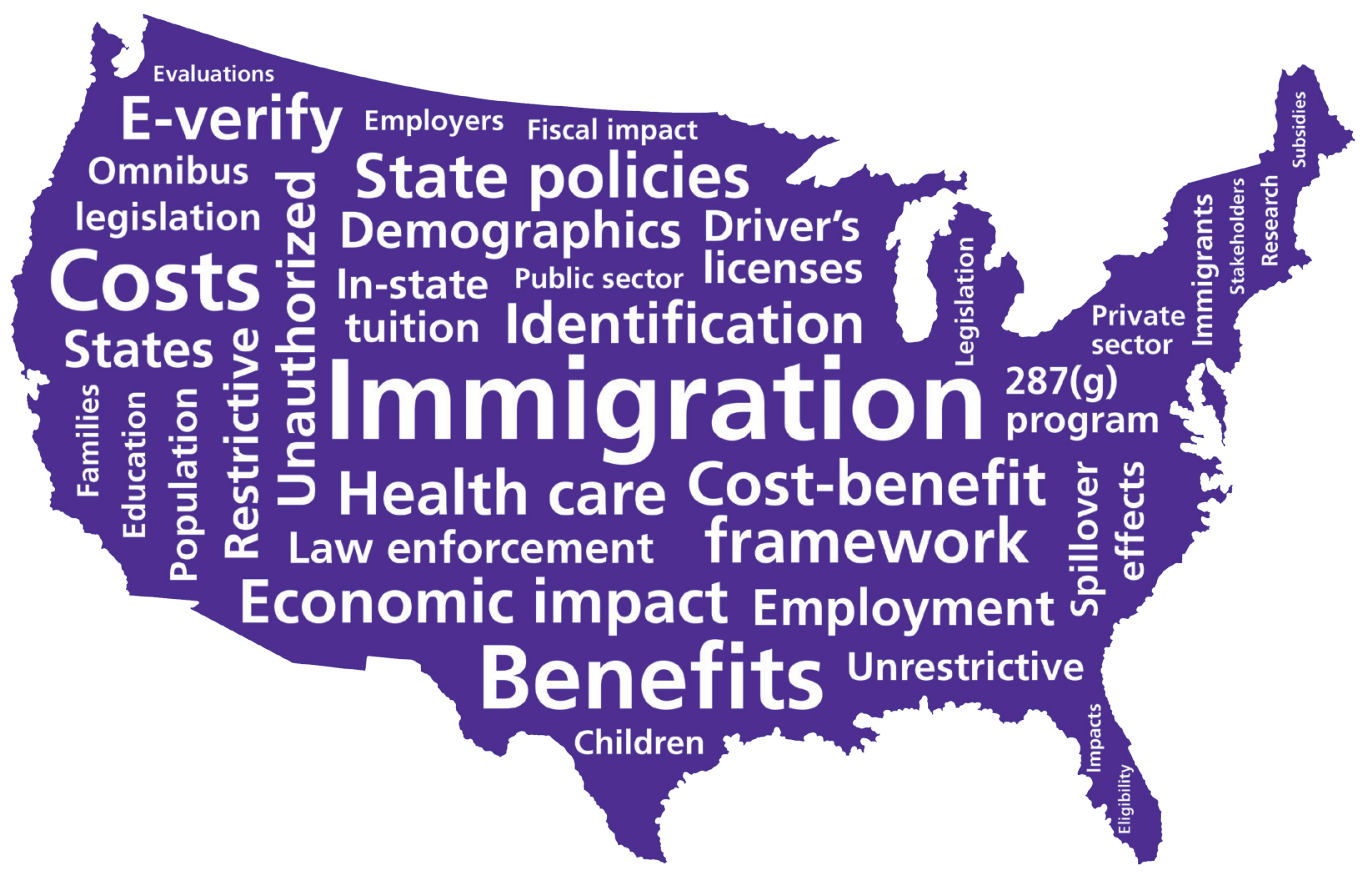

Supported by the John D. and Catherine T. MacArthur Foundation 
For more information on this publication, visit www.rand.org/t/rr1397

Published by the RAND Corporation, Santa Monica, Calif.

(C) Copyright 2016 RAND Corporation

RAND $^{\circledR}$ is a registered trademark.

\section{Limited Print and Electronic Distribution Rights}

This document and trademark(s) contained herein are protected by law. This representation of RAND intellectual property is provided for noncommercial use only. Unauthorized posting of this publication online is prohibited. Permission is given to duplicate this document for personal use only, as long as it is unaltered and complete. Permission is required from RAND to reproduce, or reuse in another form, any of its research documents for commercial use. For information on reprint and linking permissions, please visit www.rand.org/pubs/permissions.html.

The RAND Corporation is a research organization that develops solutions to public policy challenges to help make communities throughout the world safer and more secure, healthier and more prosperous. RAND is nonprofit, nonpartisan, and committed to the public interest.

RAND's publications do not necessarily reflect the opinions of its research clients and sponsors.

\section{Support RAND}

Make a tax-deductible charitable contribution at

www.rand.org/giving/contribute

www.rand.org 


\section{Preface}

Traditionally, immigration policy has been a federal responsibility, but, in the past decade, states have begun to adopt policies through legislation and other actions to respond to trends in unauthorized immigration. In some states, policies have taken the form of omnibus legislation designed to place restrictions on immigrants who are in the United States without authorization, through actions of law enforcement and employers, as well as limits in other aspects of public life. In other states, policies have been adopted one by one, such as requiring employers in the public and private sectors to verify employment eligibility through E-Verify, to preclude access to driver's licenses for individuals who are not authorized to be in the country, and to exclude unauthorized students from eligibility for in-state tuition at public colleges and universities. At the same time, some states have also adopted policies toward unauthorized immigrants that are unrestrictive - for example, by making driver's licenses available to all regardless of immigration status or basing access to in-state tuition solely on residency requirements, regardless of immigration status.

The expanding role of states in these areas of policy raises questions about the consequences of state-level action for various stakeholders in the public and private sectors. Within this context, the goals of this study are to

- develop a cost-benefit framework for classifying the potential impacts of specific statelevel policies, identifying the potential domains of impact and how different stakeholders in the public and private sectors would be affected

- review the research literature to identify empirical evidence, where it exists, regarding the likely magnitudes of the impacts of specific state-level immigration-related policies

- use the cost-benefit framework, together with the assembled empirical evidence, to assess the rigor and relevance of existing studies of the fiscal and economic impacts of specific state-level immigration policy actions.

The study also reviews the landscape of state-level immigration policies - both omnibus legislation and targeted policies.

The study was funded through a grant from the John D. and Catherine T. MacArthur Foundation. It should be of interest to policymakers at all levels of government, as well stakeholders in the private sector, focused on state-level immigration policy and the costs and benefits associated with state policy actions pertaining to unauthorized immigrants.

This research was conducted in RAND Labor and Population. Additional information about RAND is available at www.rand.org. 



\section{Contents}

Preface

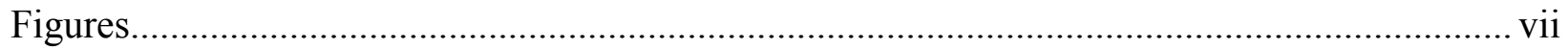

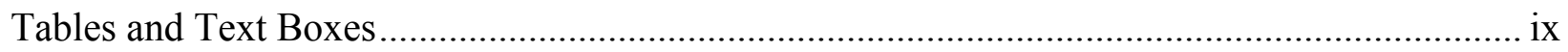

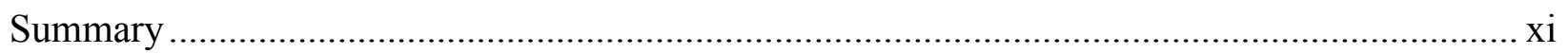

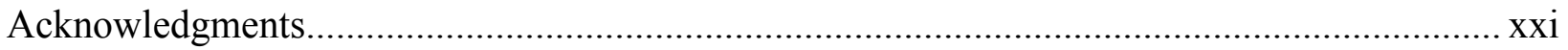

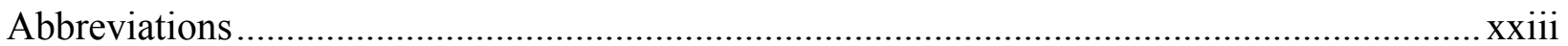

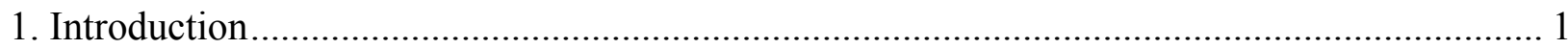

2. Landscape of State-Level Immigration Policies ................................................................ 3

Overview of State-Level Immigration Policy Action............................................................ 3

State-Level Omnibus Legislation .................................................................................. 5

State-Level Specific Policies ........................................................................................ 8

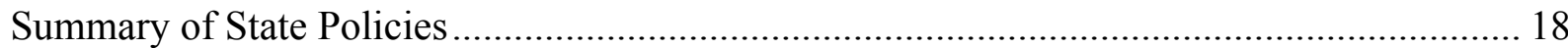

3. Framework for Analyzing State-Level Immigration Policies............................................ 21

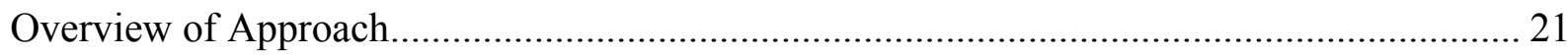

Expected Effect of State-Level Policies on the Number of Immigrants.............................. 25

Framework Applied to State and Local Immigration-Related Law Enforcement Policies ...... 32

Framework Applied to E-Verify and Other Status Verification Systems ............................ 40

Framework Applied to Omnibus Legislation or Multiple Restrictive Policies ...................... 49

Framework Applied to Eligibility for In-State Tuition and Other Financial Aid................... 53

Framework Applied to Driver's License Eligibility ........................................................... 59

Framework Applied to Health Care Access for Pregnant Women and Children .................... 62

4. Analysis of Existing CBAs of State-Level Immigration Policy .......................................... 67

Existing Literature on Costs and Benefits of State-Level Immigration Policies ..................... 67

Assessment of a CBA of the Maryland Dream Act........................................................... 69

Assessment of a CBA of California's Proposition 187 Provision Regarding Access to

Publicly Funded Health Care ................................................................................................. 73

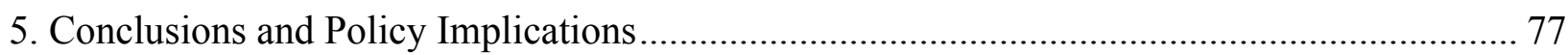

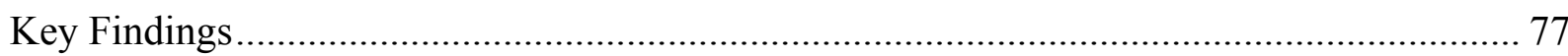

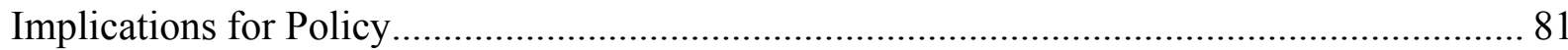

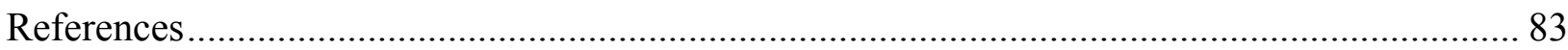





\section{Figures}

Figure S.1. Summary Status of State Immigration Policy as of June 2015 .............................xiii

Figure 2.1. Status of State E-Verify Policy as of June 2015 ................................................ 12

Figure 2.2. Status of State In-State Tuition Policy as of June 2015 ...................................... 14

Figure 2.3. Status of State Driver's License Policy as of June 2015 ..................................... 15

Figure 2.4. Status of State Subsidized Health Care Policy as of June 2015 ............................ 17

Figure 2.5. Summary Status of State Immigration Policy as of June 2015 ............................. 18 



\section{Tables and Text Boxes}

\section{Tables}

Table S.1. State Immigration Policies Included in Cost-Benefit Framework: Status Quo,

Policy Alternative, Direction of Change, and State Count.... xii

Table 2.1. State Legislation and Resolutions Related to Immigration and Immigrants, 2005-2014... 4

Table 2.2. States with Immigration Omnibus Legislation as of June 2015 ............................... 5

Table 2.3. State Immigration Policy Status as of June 2015 .................................................. 9

Table 3.1. Illustrative Matrix of Impacts by Stakeholder for a Given Policy............................. 21

Table 3.2. State Immigration Policies Included in Cost-Benefit Framework: Status Quo,

Policy Alternative, and Direction of Change ......................................................... 22

Table 3.3. Domains of Potential Demographic, Economic, and Social Impact of State

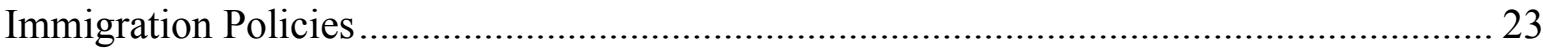

Table 3.4. Potential Impacts of Expanded State- and Local-Level Immigration-Related

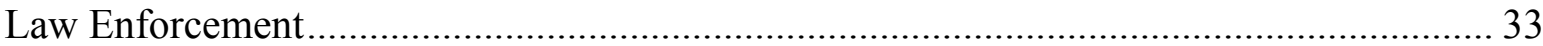

Table 3.5. Studies Assessing Impacts of Expanding State- and Local-Level Immigration-

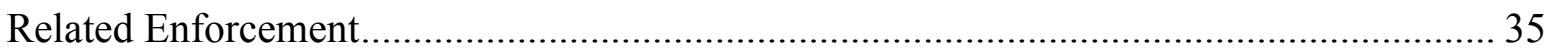

Table 3.6. Accounting for Potential Costs and Benefits of Expanding State- and Local-Level

Immigration-Related Enforcement .......................................................................... 38

Table 3.7. Potential Impacts of State Mandate to Use E-Verify or Other Status Verification

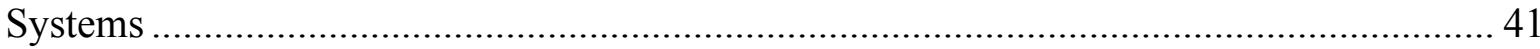

Table 3.8. Studies Assessing Impacts of Mandating the Use of E-Verify or Other Status

Verification Systems ...................................................................................................... 43

Table 3.9. Accounting for Potential Costs and Benefits of Mandating the Use of E-Verify

or Other Status Verification Systems......................................................................... 48

Table 3.10. Studies Assessing Impacts of Omnibus Legislation or Combinations of

Restrictive Policies

Table 3.11. Potential Impacts of Providing Access to In-State Tuition or Other Financial Aid

Regardless of Immigration Status ............................................................................... 54

Table 3.12. Studies Assessing Impacts of Providing Access to In-State Tuition or Other

Financial Aid Regardless of Immigration Status ....................................................... 55

Table 3.13. Accounting for Potential Costs and Benefits of Providing Access to In-State

Tuition or Other Financial Aid Regardless of Immigration Status ................................. 58

Table 3.14. Potential Impacts of Providing Driver's Licenses Regardless of Immigration Status 
Table 3.15. Studies Assessing Impacts of Providing Driver's Licenses Regardless of Immigration

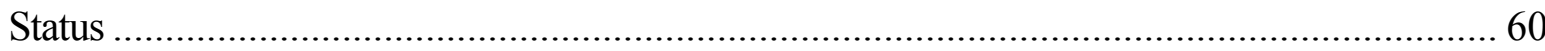

Table 3.16. Accounting for Potential Costs and Benefits of Providing Driver's Licenses

Regardless of Immigration Status

Table 3.17. Potential Impacts of Extending Access to Subsidized Prenatal Care and Child Health Insurance for Unauthorized Immigrants 63

Table 3.18. Studies Assessing Impacts of Unauthorized Immigrants' Access to Subsidized Prenatal Care. 64

Table 3.19. Accounting for Potential Costs and Benefits of Extending Access to Subsidized Prenatal Care and Child Health Insurance for Unauthorized Immigrants ...............................6 65

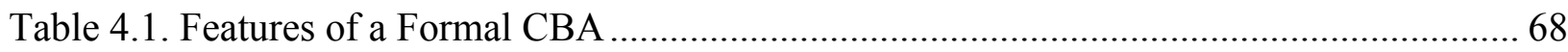

Table 4.2. Assessment of CBA of Maryland Dream Act ……………………………............. 72

Table 4.3. Assessment of CBA of California Proposition 187 Prenatal Care Provisions ............ 75

\section{Text Boxes}

Text Box 3.1. Literature on Immigrants and Wages of Natives ...... 27

Text Box 3.2. Literature on Immigration and Crime 


\section{Summary}

In the absence of comprehensive federal immigration reform, almost all states have taken a more active role in the past 15 years in setting policy with respect to unauthorized immigrants. This expanded state interest in immigration policy stems from the growing number of unauthorized immigrants in the United States, which increased from 3.5 million in 1990 to a peak of 12.2 million in 2007. While the Great Recession played a roll in halting the growing numbers, an estimated 11.3 million unauthorized immigrants were living in the United States as of March 2013.

Some states have primarily enacted legislation and implemented other policy actions that place greater restrictions on unauthorized immigrants in the domains of employment, education, housing, health care, and other aspects of daily life. These policies targeting unauthorized immigrants include expanding local law enforcement involvement in enforcing federal immigration laws, mandating that employers verify work eligibility, prohibiting access to discounted tuition for otherwise eligible unauthorized immigrants, blocking eligibility for state driver's licenses, and excluding access to publicly subsidized prenatal care and child health insurance. At the same time, other states have taken the opposite course and adopted policies with the reverse intent relative to the status quo: divorcing immigration status from access to in-state tuition and allowing eligibility for state-issued driver's licenses and access to subsidized health care. Still other states have adopted a mixture of these policies - restrictive toward unauthorized immigrants in some areas but unrestrictive in others. By our accounting, as of June 2015, all but 11 states had adopted one or more of the policies we examined, with much of the policy reform occurring in the past decade.

In the light of these policy changes, the goal of this study is to document the key state-level immigration-related policies and their variations, develop a cost-benefit framework for classifying the potential impacts of specific state-level policies, review the literature to determine whether there is an evidence base that confirms the expected impacts and then incorporate that research into the cost-benefit framework, and use the cost-benefit framework to assess the rigor and relevance of existing cost-benefit studies of the fiscal and economic impacts of specific state-level immigration-related policies.

In the remainder of this summary, we first provide a brief sketch of the landscape of statelevel immigration policies. We then review our approach to developing a framework for assessing the costs and benefits of the state-level immigration-related policies of interest. We conclude by highlighting a series of key findings and the policy implications of our analysis.

\section{Landscape of State-Level Immigration Policies}

Information on state legislative activity, tracked since 2005 by the National Conference of State Legislatures (NCSL), shows a tenfold increase in the number of state-level immigration-related laws 
and resolutions, starting at 39 in 2005 and reaching 437 by 2013. Counting laws alone, the tally begins with 39 in 2005, climbs to a peak of 240 in 2007, and levels off between 150 and 200 from 2010 to 2013. Since 2007, this legislative activity has involved 40 or more states each year.

Table S.1 delineates the major policy reforms that we examine in the study. Starting with Arizona in July 2010 and concluding with South Carolina in June 2011, six states enacted omnibus legislation that incorporated multiple restrictive provisions toward unauthorized immigrants. All bills included requirements for local enforcement of federal immigration laws, a feature that other states adopted as stand-alone legislation or through participation in the

Table S.1. State Immigration Policies Included in Cost-Benefit Framework: Status Quo, Policy Alternative, Direction of Change, and State Count

\begin{tabular}{|c|c|c|c|c|}
\hline Policy & Status Quo & Policy Alternative & $\begin{array}{c}\text { Direction of } \\
\text { Change }\end{array}$ & $\begin{array}{c}\text { Number of States } \\
\text { with Policy as of } \\
\text { June } 2015\end{array}$ \\
\hline $\begin{array}{l}\text { Omnibus } \\
\text { immigration } \\
\text { legislation }\end{array}$ & $\begin{array}{l}\text { State has no express policy } \\
\text { regarding immigration-related } \\
\text { law enforcement, use of E- } \\
\text { Verify or other status } \\
\text { verification systems, in-state } \\
\text { tuition, driver's license, } \\
\text { access to public benefits }\end{array}$ & $\begin{array}{l}\text { State places multiple } \\
\text { restrictions on unauthorized } \\
\text { immigrations in such domains } \\
\text { as law enforcement, } \\
\text { employment, higher } \\
\text { education, driver's licenses, } \\
\text { and access to public benefits }\end{array}$ & $\begin{array}{l}\text { Restrictive } \\
\text { toward } \\
\text { unauthorized } \\
\text { immigrants }\end{array}$ & 6 \\
\hline $\begin{array}{l}\text { Immigration- } \\
\text { related law } \\
\text { enforcement }\end{array}$ & $\begin{array}{l}\text { State has no express policy } \\
\text { to enforce federal } \\
\text { immigration policy }\end{array}$ & $\begin{array}{l}\text { State prohibits law } \\
\text { enforcement from restricting } \\
\text { enforcement of federal } \\
\text { immigration laws }\end{array}$ & $\begin{array}{l}\text { Restrictive } \\
\text { toward } \\
\text { unauthorized } \\
\text { immigrants }\end{array}$ & $8^{a}$ \\
\hline $\begin{array}{l}\text { E-Verify or other } \\
\text { status } \\
\text { verification } \\
\text { systems }\end{array}$ & $\begin{array}{l}\text { Use of E-Verify by public and } \\
\text { private employers in the state } \\
\text { is voluntary }\end{array}$ & $\begin{array}{l}\text { Use of E-Verify is mandatory } \\
\text { for all or some subset of } \\
\text { public and private employers }\end{array}$ & $\begin{array}{l}\text { Restrictive } \\
\text { toward } \\
\text { unauthorized } \\
\text { immigrants }\end{array}$ & $22^{b}$ \\
\hline $\begin{array}{l}\text { In-state tuition } \\
\text { and other } \\
\text { financial aid }\end{array}$ & $\begin{array}{l}\text { State does not allow } \\
\text { unauthorized immigrants to } \\
\text { receive in-state tuition or } \\
\text { other financial aid at public } \\
\text { colleges and universities for } \\
\text { which they otherwise qualify }\end{array}$ & $\begin{array}{l}\text { State allows unauthorized } \\
\text { immigrants to receive in-state } \\
\text { tuition (and financial aid) at } \\
\text { public colleges and } \\
\text { universities provided they } \\
\text { meet graduation, residency, } \\
\text { and other requirements }\end{array}$ & $\begin{array}{l}\text { Unrestrictive } \\
\text { toward } \\
\text { unauthorized } \\
\text { immigrants }\end{array}$ & $20^{C}$ \\
\hline $\begin{array}{l}\text { Driver's } \\
\text { license } \\
\text { eligibility }\end{array}$ & $\begin{array}{l}\text { Unauthorized immigrants are } \\
\text { not eligible for state-issued } \\
\text { driver's license }\end{array}$ & $\begin{array}{l}\text { Unauthorized immigrants are } \\
\text { eligible for state-issued } \\
\text { driver's license }\end{array}$ & $\begin{array}{l}\text { Unrestrictive } \\
\text { toward } \\
\text { unauthorized } \\
\text { immigrants }\end{array}$ & 12 \\
\hline $\begin{array}{l}\text { Health care } \\
\text { access for } \\
\text { pregnant } \\
\text { women and } \\
\text { children }\end{array}$ & $\begin{array}{l}\text { Unauthorized immigrants do } \\
\text { not qualify for publicly } \\
\text { subsidized health insurance } \\
\text { or medical care }\end{array}$ & $\begin{array}{l}\text { Unauthorized pregnant } \\
\text { women are eligible for } \\
\text { subsidized prenatal care } \\
\text { and/or unauthorized children } \\
\text { are eligible for publicly } \\
\text { subsidized health insurance }\end{array}$ & $\begin{array}{l}\text { Unrestrictive } \\
\text { toward } \\
\text { unauthorized } \\
\text { immigrants }\end{array}$ & 18 \\
\hline
\end{tabular}


U.S. Immigration and Customs Enforcement (ICE) 287 (g) program. ${ }^{1}$ If not already required as part of separate legislation, most omnibus bills also mandated the use of E-Verify on the part of all employers or a subset of employers (typically public agencies or public contractors) to determine whether a prospective employee is a U.S. citizen or otherwise legally authorized to work. ${ }^{2}$ The other three policies listed in Table S.1 have, with a few exceptions, been adopted by states as unrestrictive policies that eliminate immigration status as a criteria for accessing in-state tuition (and in some cases, other financial aid) at publicly funded colleges and universities, obtaining a driver's license, or qualifying for subsidized prenatal care and children's health insurance.

The number of states with each of the policies as of June 2015 ranged from six (omnibus legislation) to 22 (mandated use of E-Verify) (Table S.1). Figure S.1 summarizes the combined policy landscape in each state as of mid-2015, identifying those with three or more restrictive

Figure S.1. Summary Status of State Immigration Policy as of June 2015

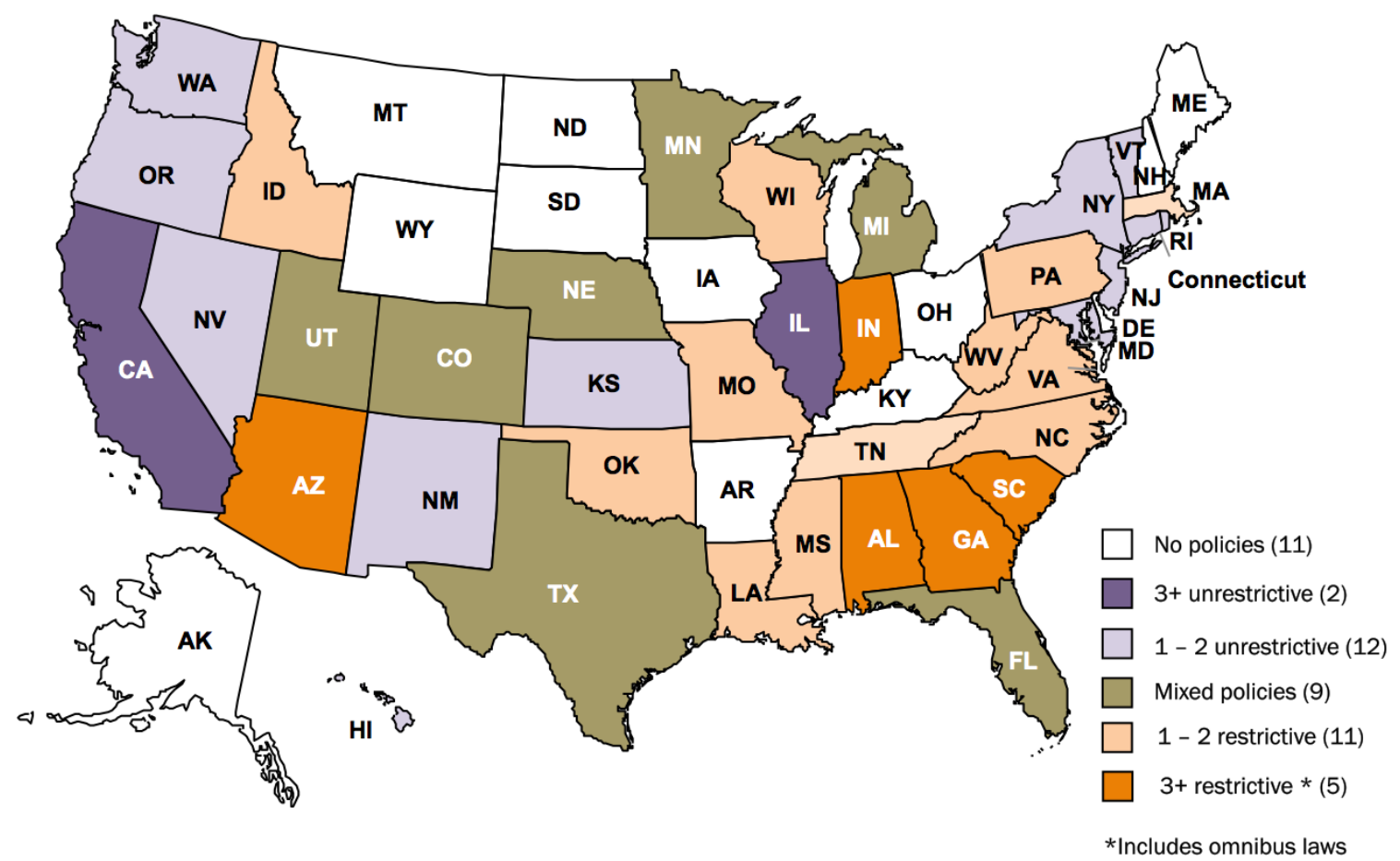

SOURCES: Johnston and Morse (2012), Kostandini, Mykerezi, and Escalante (2013), Newman and Todd (2013), Teigen and Morse (2013), Morse (2014), Mathema (2015), Mendoza (2015), Mendoza and Ostrander (2015), Mendoza and Shaikh (2015), NCSL (2015a, 2015b), and NILC (2015b).

\footnotetext{
${ }^{1}$ Under Section 287(g) of the Immigration and Nationality Act, codified at 8 USC 1357(g), ICE can establish voluntary cooperative agreements with state and local authorities to permit local law enforcement, after receiving appropriate training, to perform immigration enforcement functions under the supervision of ICE. These programs were most active between 2002 and 2012.

${ }^{2}$ E-Verify is an online system, operated by the U.S. Citizenship and Immigration Services, which allows employers to verify the identification and work authorization documents of new hires based on federal databases.
} 
policies (dark orange), one or two restrictive policies (light orange), one or two unrestrictive policies (light purple), three or more unrestrictive policies (dark purple), a combination of both restrictive and unrestrictive policies (brown), and no policies (white). Our analysis of state immigration policy shows that by June 2015, all but 11 states had at least one of the policies listed in Table S.1. States were almost evenly balanced between those with only restrictive policies (16 states) and those with only unrestrictive policies (14 states). Interestingly, nine states had adopted both types of policies, typically a restrictive version of E-Verify but an unrestrictive version of in-state tuition or driver's license access.

\section{Approach to Identifying the Costs and Benefits of State-Level Immigration- Related Policies}

A key objective for this study was the development of a cost-benefit framework for understanding the potential impacts of the state-level immigration policies listed in Table S.1. The framework relies on determining the set of effects (also referred to as impacts or outcomes) that a policy may have and how those effects create costs or benefits for the following stakeholders: unauthorized immigrants, authorized immigrants (including naturalized U.S. citizens) and the native-born, employers, and state and local governments. Aggregating across stakeholders provides the societal perspective of the costs and benefits of any given policy.

To develop the cost-benefit framework for any given policy in Table S.1, we first identified the expected changes, based on theoretical considerations and other empirical evidence, in the number of unauthorized immigrants in the state and other key economic and social outcomes, as well as the implications for state and local government budgets. We then reviewed empirical studies that have examined the causal impact of the policy as implemented. Most of the available research exploits the variation across states and through time in the policy environment to estimate the impact of one or more policies (or policy variants) on the level and share of key population subgroups (e.g., unauthorized immigrants), labor market outcomes (e.g., employment and wages), and other relevant outcomes (e.g., educational attainment in the case of in-state tuition policy).

One use of the series of cost-benefit frameworks we constructed is to illuminate the array of impacts that any given policy may have and which stakeholders are expected to experience costs or benefits as a result. Each framework can be a guide to the development of future cost-benefit analyses (CBAs) of the policy or in the assessment of the quality of prior CBAs. To illustrate the latter use, we searched the literature and identified two formal CBAs related to Table S.1 policies: one assessing the costs and benefits of Maryland's 2012 Dream Act, which allowed unauthorized students to qualify for in-state tuition if they met a series of requirements; the other an assessment of the costs and benefits of a provision in California's 1994 Proposition 187 that denied unauthorized immigrants access to publicly subsidized prenatal care. We then reviewed 
each CBA for completeness - whether they capture all potential costs and benefits for each stakeholder of interest — and consistency with existing empirical evidence of policy impacts.

\section{Key Findings Regarding Costs and Benefits of State-Level Immigration- Related Policies}

These cost-benefit frameworks and associated literature reviews produced a number of key findings, which we summarize here.

\section{State-Level Immigration Policies May Produce Impacts in Multiple Domains}

State-level immigration-related policies are typically motivated by concerns about the size of the unauthorized immigrant population in a state, competition in the labor market between unauthorized immigrants and other workers (e.g., authorized immigrants and native workers), and the use of public services by unauthorized immigrants, among other demographic, economic, and social impacts of unauthorized immigration. Regardless of the type of state-related immigration policy—whether omnibus legislation or a more targeted policy change — it is important to recognize that policy impacts may accrue in multiple policy domains.

Indeed, both theoretical predictions and empirical findings indicate that, depending on the policy, impacts may be found in the size of the unauthorized population in the state; the level and distribution of state economic activity; the labor market in terms of the level of employment and wages, the sectoral composition of employment, and the relative wages across worker subgroups based on skill; primary, secondary, and postsecondary education in terms of enrollment and attainment; law enforcement and the criminal justice system; the social welfare system; population health and utilization of health care; and state and local government taxes and expenditures. One advantage of a CBA is that it provides a framework for undertaking a comprehensive assessment of the full range of potential policy impacts and for determining the costs and benefits in aggregate and for specific stakeholders in the public and private sectors.

\section{Some Expected Effects Have a Clear Direction of Impact; Others Are More Uncertain}

When assessing the potential impacts of state-level immigration-related policies, relative to the status quo, some expected effects can be clearly designated as positive, negative, or neutral. In the case of policies that are restrictive toward unauthorized immigrants (e.g., requirements for the use of E-Verify), the first-order effects for the unauthorized immigrant population are typically unfavorable (i.e., costs exceed benefits), and the reverse holds when policies are unrestrictive toward unauthorized immigrants. For example, when states mandate the use of EVerify, unauthorized immigrants can be expected to experience decreased employment with the commensurate loss of earnings. By comparison, when states make in-state tuition available regardless of immigration status, unauthorized immigrants unambiguously gain from both lower out-of-pocket education costs and higher lifetime earnings when their educational attainment 
increases. Other outcomes, typically second-order effects through changes in labor supply or labor demand, are less certain in terms of their expect net benefits. With the E-Verify example, some unauthorized immigrants may experience net gains if wages increase for lower-skilled workers (because of reduced supply) and if they are able to remain employed through selfemployment or work in a sector that is not covered by the E-Verify requirement. Given these uncertainties in the policy impacts, it is important to undertake empirical research to assess the realized outcomes for unauthorized immigrants and other population groups in states adopting immigration-related policies relative to those that do not.

\section{Expected Effects Often Go Beyond Those for Unauthorized Immigrants to Include Potential Spillover Effects for Other Stakeholders}

Although unauthorized immigrants are often the target of state-level immigration policy, there are theoretical reasons to expect spillover consequences for authorized immigrants and the native-born population. This is especially true when policies affect the labor market through changes in labor supply or labor demand. Spillover consequences may also be a consideration in mixed-status families where one or both parents are unauthorized immigrants but some or all of their children are native-born U.S. citizens.

In each of the policy areas we considered, we identified potential impacts for authorized immigrants and natives (including the U.S. citizen children of unauthorized immigrant parents), effects that were often unintended and theoretically ambiguous in terms of their net effect. To the extent that state-level immigration policies also affect state and local governments (or even the federal government), those effects ultimately affect nontargeted populations as taxpayers or recipients of government services. For example, expanding state- and local-level immigrationrelated enforcement may affect authorized immigrants and the native-born if law enforcement costs increase overall or if greater immigration-related enforcement crowds out other law enforcement activity.

Such spillover effects have received less attention in the empirical literature, but there is suggestive evidence that nontargeted groups may lose or gain as well. One study of stricter enforcement of immigration laws at the local level found reduced participation in Medicaid on the part of U.S. citizen children whose parents were unauthorized. Studies of the impact of mandating E-Verify indicated that naturalized U.S. citizens and native-born populations with low education levels also experienced declines in employment, potentially because of a decline in labor demand. On the other hand, studies of states extending in-state tuition to unauthorized immigrants do not indicate that there is crowding out of authorized immigrants or the native-born from higher education. The potential for such spillover gains or losses for other population groups is important to consider in any comprehensive accounting of policy impacts. 


\section{A Growing Literature Documents the Effects of State-Level Policies, But Important Gaps Remain}

As the volume of state-level immigration-related policies has expanded, there has been growth in the number of research studies that seek to measure the causal effects of the policies. The policies that have received most of the attention by researchers include expanding state- and local-level immigration-related enforcement, mandating the use of E-Verify, restrictive omnibus legislation, and making in-state tuition available regardless of immigration status. Policies that have received less attention include making driver's licenses available regardless of immigration status and extending coverage for prenatal care and children's health insurance to low-income immigrants regardless of status. Although there is much to be learned from this body of evidence, it is also important to keep in mind some of the limitations. For example, because the policy changes are more recent, most studies capture only short-term effects. In addition, the effects of any given policy may differ from the estimates available in the literature once more states have adopted the policy or it becomes national policy.

\section{Few Formal CBAs of State-Level Immigration Policies Have Been Conducted}

Given that the net effects of the state-level immigration-related policies we examined are often ambiguous, a formal CBA is required to more fully understand the expected net benefits of a given policy for any one stakeholder group or for society as a whole. However, our literature search identified few formal CBAs of the set of state-level immigration-related policies we examine in this study. Numerous analyses calculate the net fiscal or economic impact of immigration in total or unauthorized immigration in particular, but those studies do not provide analyses of specific policy impacts. Other studies that focus on costs or benefits of specific immigration-related policies or bundles of policies (i.e., omnibus legislation) are often designed to support or oppose the policy change and therefore do not provide a comprehensive, balanced assessment of all costs and benefits to all relevant stakeholders. In many cases, such studies have not taken advantage of empirical estimates of policy impacts from the growing research literature and instead rely on ad hoc assumptions about policy impacts.

\section{Formal CBAs of State-Level Immigration Policies Inform Overall Economic and Fiscal Impacts as Well as Distributional Consequences}

The two CBAs we reviewed demonstrate the insights that can be gleaned from drawing on research evidence to estimate policy impacts; quantify their dollar costs, benefits, and net benefits in aggregate; and allocate costs and benefits across different stakeholder groups. The framework also helps to identify what is omitted in any given analysis. For example, the two CBAs we reviewed do not capture the potential impacts from cross-state migration induced by the policy change. This reflects, in part, the absence of empirical studies that document these impacts. In addition, the CBA of California's Proposition 187, by taking a government 
perspective, omits potential private-sector costs and benefits (i.e., for unauthorized immigrants, authorized immigrants and natives, and employers).

Future CBAs can take advantage of the growing literature documenting the impacts of statelevel immigration-related policies, drawing on the studies, such as those reviewed in this report, that use the best available methods to identify the causal effects of the policies. Analysts should take care to understand the limitations of any one study or group of studies, such as their generalizability to the policy context being analyzed for the CBA. Even where there is no empirical evidence to support generating a policy impact or the perspective omits some stakeholders, the analysis can still document whether the unmeasured impacts are likely to results in net benefits or net costs and which stakeholder groups will be affected.

\section{Predominance of Certain State Policies May Reflect Underlying Cost-Benefit Calculations}

Although formal CBAs focused on state-level immigration-related policies are relatively sparse, the existing findings suggest that policymakers and the public may have been performing such cost-benefit calculations implicitly in making immigration policy decisions at the state and local level. For example, the CBA of the Maryland Dream Act shows that granting unauthorized immigrants access to in-state tuition would pass a cost-benefit test in aggregate and for the public sector under a range of assumptions. Interestingly, each of the top six states where unauthorized immigrants reside (California, Florida, Illinois, New Jersey, New York, and Texas) has extended in-state tuition to unauthorized immigrants, and California and Texas make state financial aid available as well. Overall, 20 states have adopted some form of in-state tuition eligibility for unauthorized immigrants, making it the most prevalent of the unrestrictive policies we examine. This suggests that policymakers and the public in these states have recognized the likely positive economic return and savings to government from investing in the education of all immigrants, regardless of status.

\section{Policy Implications}

Across states and localities, the adoption of immigration-related policies has proceeded apace, especially in the absence of comprehensive federal immigration reform. Often, the adoption of the policy changes reviewed in this study has been contentious, whether taken up in the state legislature or at the ballot box. These debates reflect the fact that the policies reviewed here have distributional consequences, with winners and losers both within key stakeholder groups (e.g., subgroups among unauthorized immigrants) and across those groups (e.g., unauthorized immigrants versus authorized immigrants).

The use of a cost-benefit framework, such as the one developed in this study, provides an avenue for developing a more objective, balanced perspective on the expected favorable and unfavorable effects of any given state-level immigration-related policy, the dollar values 
associated with those outcomes, whether society as a whole benefits from the policy change, and which stakeholder groups are likely to experience net gains versus net losses. The framework can be useful for evaluating policies already in place or for assessing the likely outcomes for a policy change under deliberation. In can also be used as a tool for verifying the comprehensiveness of CBAs of past policies or planned future policies.

The recent pace of state-level policymaking with respect to unauthorized immigrants and immigration suggests this will be an ongoing area for governors, legislators, and other decisionmakers to consider. The cost-benefit framework developed in this study can readily be adapted to modifications to the policies considered here or to new policies on the horizon. Regardless, a comprehensive cost-benefit framework provides a uniform accounting framework that can be used to evaluate prior research on the impact of state immigration policies and guide future studies. 



\section{Acknowledgments}

We would like to thank Tara Magner and Valerie Chang at the John D. and Catherine T. MacArthur Foundation for their valuable input during the course of the project. We also received feedback on intermediate findings from members of the National Research Council Panel on Economic and Fiscal Consequences of Immigration. At RAND, Semira Ahdiyyih provided excellent research support.

The RAND Labor and Population review process employs anonymous peer reviewers, including at least one reviewer who is external to RAND. We benefited from the thorough and constructive feedback provided by two anonymous reviewers. We also thank Arwen Bicknell for editing the report, Beth Bernstein for managing the document production, and Eileen LaRusso for designing the cover. 



\section{Abbreviations}

CBA cost-benefit analysis

CBO Congressional Budget Office

CHIP Children's Health Insurance Program

CPS Current Population Survey

DACA Deferred Action for Childhood Arrivals

DHS U.S. Department of Homeland Security

GDP gross domestic product

HB House Bill

ICE U.S. Immigration and Customs Enforcement

IIRIRA Illegal Immigration Reform and Immigrant Responsibility Act of 1996

LAWA Legal Arizona Workers Act of 2007

MSA Metropolitan Statistical Area

NCSL National Conference of State Legislatures

NILC National Immigration Law Center

PRWORA Personal Responsibility and Work Opportunity Reconciliation Act

SB Senate Bill

STI sexually transmitted infection 


\section{Introduction}

According to the latest estimates from the Pew Research Center, about 11.3 million unauthorized immigrants were in the United States as of March 2013, including individuals who entered the country legally and overstayed their visas, as well as those who entered without inspection (i.e., without valid documents) (Passel et al., 2014). Historical data show a steady climb in the number of unauthorized immigrants, from an estimated 3.5 million in 1990 to a peak of 12.2 million in 2007, prior to the Great Recession. Most of these immigrants are adults - 10.4 million — and a growing share (38 percent as of 2012) are residing with their U.S.-born minor or adult children. Many unauthorized immigrants remain in the United States for extended periods of time. As of 2012, an estimated 62 percent of immigrant adults had lived in the country for ten years or more, while 21 percent had been resident for two decades or more (Passel et al., 2014).

Although immigration policy and immigration enforcement traditionally have been federal responsibilities, a number of states have begun to take more active roles in the immigration policy arena (Varsanyi, 2010). Some states have responded to growing concerns about the economic and fiscal impact of unauthorized immigration with policies designed to reduce the number of unauthorized immigrants already in the state or to discourage newcomers. In 2010, for instance, Arizona was one of the first states to enact a more punitive law, with such components as requiring police to check the immigration status of detainees suspected of being unauthorized and making it a criminal act to seek employment when not authorized to work (one of three provisions overturned by the U.S. Supreme Court in June 2012).

The Beason-Hammon Alabama Taxpayer and Citizen Protection Act, enacted in June 2011, likewise contains a number of restrictive policies, such as prohibiting unauthorized immigrants from receiving state or local public benefits (e.g., education or health care) and requiring the police to take steps to determine a person's legal status in the course of their routine actions. Four other states have adopted similar omnibus laws (namely Georgia, Indiana, South Carolina, and Utah), and there are hundreds of other examples of proposed or enacted restrictions on unauthorized immigrants at the state and local level in the past decade. Other arenas for state involvement in immigration policy include forming partnerships between federal immigration agencies and state and local law enforcement agencies to apprehend and deport fugitive aliensthose who have ignored deportation orders (Saunders, Lim, and Prosnitz, 2010; Pew Charitable Trusts, 2014a).

At the same time that some states have sought to restrict opportunities for unauthorized immigrants, other states have enacted legislation or other policies that do not impose restrictions on their ability to participate in the state economy or that eliminate immigration status as a factor in determining eligibility for certain public benefits. In 2013, for example, eight states adopted legislation allowing access to a driver's license without regard to immigration status, a policy 
already in place in three other states. In-state tuition at state institutions of higher education and even financial aid is available to students regardless of immigration status in growing number of states, as well. Such states tend to be more supportive of immigrants and immigration, more generally, and seek to attract immigrants as a means of population growth and economic revitalization. These initiatives include programs that provide outreach and support to immigrants pertaining to employment, housing, and social services, and that more generally seek to support immigrants' equal access to and full inclusion in the economy, as well as in the civic and cultural life of the community (Gambetta and Gedrimaite, 2014; Kerr, McDaniel, and Guinan, 2014; Waslin, 2015).

Although much of the policy debate in the past several years has centered on the prospects for and nature of federal immigration reform, the shifts in policy at the state level toward unauthorized immigrants represent a significant change that has garnered somewhat less attention. To the extent that these policies have gained currency, it is usually out of concern for the costs that unauthorized immigrants impose on the economy and the public sector, while others contend that immigration as a whole is beneficial for both the public and private sectors. Often, such economic analyses are not sufficiently comprehensive to fully capture the range of expected impacts and the associated costs and benefits. Thus, there is a need for an objective and comprehensive assessment of the key policies in play at the state level and their expected impacts, both direct and indirect.

With this in mind, the goals of this study are threefold. First, we develop a cost-benefit framework for classifying the potential impacts of specific state-level policies, identifying the potential domains of impact and how different stakeholders in the public and private sectors would be affected. Second, we review the research literature to identify empirical evidence, where it exists, regarding the likely magnitudes of the impacts of specific state-level immigration-related policies. Third, we use the cost-benefit framework we developed, together with the assembled empirical evidence, to assess the rigor and relevance of existing studies of the fiscal and economic impacts of specific state-level immigration policy actions. For example, do the studies consider a comprehensive list of both the costs and benefits of a given policy, or are some domains of impact overlooked?

In support of our three objectives, we begin in the next chapter by reviewing the landscape of state-level immigration policies - both omnibus legislation and targeted policy areas. Chapter Three presents our comprehensive framework for considering the domains of impact associated with specific policies and how different stakeholders are likely to be affected. We also review the empirical evidence regarding the likely magnitudes of the hypothesized impacts. Chapter Four draws on the cost-benefit framework we develop to assess the extent to which existing costbenefit studies of state immigration policies consider the full range of potential impacts and their costs or benefits. In the final chapter, we assess the state of the knowledge base regarding the fiscal and economic impacts of state-level immigration policy. 


\section{Landscape of State-Level Immigration Policies}

Although the federal government is largely responsible for setting and enforcing immigration policy, states have taken a more active role in the past decade in a number of policy domains pertaining to employment, education, housing, health care, and other aspects of daily life for unauthorized immigrants. Much attention has focused on the extremely restrictive nature of some state laws, but other states have moved in the opposite direction of easing potential restrictions based on immigration status. In this chapter, we first provide an overview of the nature and volume of immigration-related policy taking place at the state level. We then discuss in more detail omnibus immigration bills addressing multiple aspects of policy with respect to unauthorized immigrants, followed by laws or administrative actions (e.g., executive orders, regulations) pertaining to specific policies.

\section{Overview of State-Level Immigration Policy Action}

The National Conference of State Legislatures (NCSL) has been tracking and reporting on state laws related to immigration and immigrants since 2005 (NCSL, 2015a, 2015b). The range of policies addressed by the legislation includes such key domains as education, health, employment, driver's licenses (and identification more generally) and other licenses, law enforcement, and public benefits. Other issues include voting, legal services, and human trafficking. Some legislative activity is far-reaching, such as the omnibus immigration bills passed in Arizona in 2010 and in Alabama, Georgia, Indiana, South Carolina, and Utah in 2011. Other activity pertains to narrower policy actions, such as determining criteria under which unauthorized immigrants may be admitted to practice law in the state, or providing funding for English language and citizenship classes and for migrant and refugee programs. Some legislation pertains specifically to policies toward immigrants who are lawfully present; other legislation is directed at those who are unauthorized. As we will discuss further, in some states, the enacted policies aimed to place restrictions on unauthorized immigrants and directly or indirectly reduce their numbers. In other states, policymakers have used legislation or other mechanisms with the intent of eliminating immigration status from consideration in the targeted policy sphere.

Table 2.1, based on figures complied by NCSL, documents the explosion in state legislation related to immigration and immigrants in the second half of the 2000s. Immigration-related bills introduced in state legislatures numbered about 300 in 2005, nearly doubled to 570 bills in 2006, and then nearly tripled again to almost 1,600 bills by 2007 . The level of legislative activity remained in that range until 2011 and then dipped by almost 40 percent in 2012 (coinciding with a key Supreme Court ruling that we will discuss). The high volume of legislative activity translated into an increase of enacted legislation from about 40 laws in 2005 to a peak of slightly more than 
200 laws in 2010. Together with a growing tide of legislative resolutions, there was nearly a tenfold increase in the volume of state policy activity related to immigration and immigrants from 2005 to 2010 . Table 2.1 also shows that while just 25 states were engaged in policy action as of 2005, within a few years, every state had legislative activity and almost all enacted new laws or adopted resolutions. Those states not active in any given year were often ones where the legislature was not in regular session.

Between the 2010 peak and 2014, the number of enacted laws has remained in the range of 150 to 200. Three was an unusually large number of resolutions in 2013 (253), but much of that total was attributable to Texas, which is in regular session in odd-numbered years. Based on figures compiled for the first half of 2015 (through June), it appears that the pace of activity has yet to slow. Indeed, relative to the number of laws and resolutions as of June 2013, 2015 was likely to meet or exceed the level of activity in recent years (Morse, Mendoza, et al., 2015). Even in the first half of 2015, 46 states had enacted one or more new laws or adopted one or more resolutions.

It is important to keep in mind that the legislative activity tracked by the NCSL broadly pertains to immigration or immigrants, both those legally present and those who are not, so the legislation is not exclusive to issues concerning unauthorized immigrants. Nevertheless, the volume of activity in the past decade signals the heightened policy attention devoted to immigration issues at the state level.

Table 2.1. State Legislation and Resolutions Related to Immigration and Immigrants, 2005-2014

\begin{tabular}{|c|c|c|c|c|c|c|c|}
\hline \multirow[b]{2}{*}{ Year } & \multicolumn{4}{|c|}{ Number of Laws } & \multirow{2}{*}{$\begin{array}{l}\text { Number of } \\
\text { Resolutions } \\
\text { Adopted }\end{array}$} & \multirow{2}{*}{$\begin{array}{l}\text { Total Laws } \\
\text { Enacted and } \\
\text { Resolutions } \\
\text { Adopted }\end{array}$} & \multirow{2}{*}{$\begin{array}{l}\text { Number of } \\
\text { States with } \\
\text { New Laws or } \\
\text { Resolutions }\end{array}$} \\
\hline & Introduced & $\begin{array}{c}\text { Passed in } \\
\text { Legislature }\end{array}$ & $\begin{array}{c}\text { Vetoed/ } \\
\text { (Pending) }\end{array}$ & Enacted & & & \\
\hline 2005 & $300^{a}$ & 45 & 6 & 39 & 0 & 39 & 25 \\
\hline 2006 & 570 & 90 & 6 & 84 & 12 & 96 & 32 \\
\hline 2007 & 1,562 & 252 & 12 & 240 & 50 & 290 & 46 \\
\hline 2008 & 1,305 & 145 & 3 & 142 & 64 & 206 & 41 \\
\hline 2009 & $1,500^{a}$ & 222 & 20 & 202 & 131 & 333 & 48 \\
\hline 2010 & $1,400^{\mathrm{a}}$ & 218 & 10 & 218 & 138 & 356 & 46 \\
\hline 2011 & 1,607 & 212 & 15 & 197 & 109 & 306 & 42 \\
\hline 2012 & 983 & 168 & $11^{b}$ & 156 & 111 & 267 & 44 \\
\hline 2013 & - & 192 & 7 & 185 & 253 & 438 & 45 \\
\hline 2014 & - & 177 & 6 & 171 & 117 & 288 & 43 \\
\hline $2015^{c}$ & - & 183 & $10 /(20)$ & 153 & 238 & 391 & 46 \\
\hline
\end{tabular}

SOURCE: NCSL (2015b), various annual and semiannual reports.

NOTES: Washington, D.C., is included in the counts starting in 2010 (although not counted as a state in the final column).

$-=$ not reported.

a These figures are NCSL estimates.

${ }^{\mathrm{b}}$ One bill was sent to the governor on December 27, 2012, and enacted in 2013.

${ }^{c}$ As of June 30, 2015. 


\section{State-Level Omnibus Legislation}

In July 2010, Arizona's legislature enacted the "Support Our Law Enforcement and Safe Neighborhoods Act" (Senate Bill [SB] 1070, amended by House Bill [HB] 2162), the first comprehensive state legislation designed to place restrictions on immigration and immigrants. ${ }^{1}$ Within a year, five other states had passed similar omnibus bills: Utah in March 2011, Indiana and Georgia in May 2011, and Alabama and Georgia in June 2011. Arizona's legislation, like the other states that followed, covered multiple policy domains in one bill-hence the omnibus label. The domains covered in the various state omnibus bills include the role of law enforcement with respect to unauthorized immigrants and the enforcement of federal immigration laws, employment verification and other employment restrictions, access to driver's licenses and other forms of identification, access to public social welfare benefits, and aspects of K-12 and higher education. Table 2.2 lists the six states that have passed omnibus legislation as of the end of 2014 and the key provisions of each law. The states are listed in order of enactment.

Table 2.2. States with Immigration Omnibus Legislation as of June 2015

\section{State/Legislation}

\section{Arizona}

SB1070 and HB2162

Enacted: July 2010

Effective: July 2010
Utah

H116, H466, H469, H497

Enacted: March 2011

Effective: May 2011
Indiana

SB590

Enacted: May 2011

Effective: July 2011

\section{Key Provisions}

Law enforcement: Must reasonably attempt to determine immigration status of persons involved in lawful stop, detention, or arrest; prohibits law enforcement from restricting enforcement of federal immigration laws; authorizes warrantless arrest of a person where there is probable cause of a public offense that makes the person removable from the United States

Documentation: Unlawful to fail to apply for or carry federally issued alien registration documents

Employment: Unlawful for unauthorized to apply for work, solicit work in a public place, or perform work as an employee or public contractor

Other: Unlawful to transport an alien; conceal, harbor, or shield an alien

Law enforcement: Requires verification of immigration status for felony or misdemeanor arrests and bookings; passengers in a vehicle where the operator has been detailed may, in some cases, be asked to verify their status; prohibits state or local government policy that would limit law enforcement agencies from assisting the federal government in enforcement of federal immigration laws

Public benefits: State agencies and contractors must verify immigration status regarding application for state and local public services or benefits

Other: Establishes a pilot migrant worker visa program

Law enforcement: Department of Corrections must verify citizenship or immigration status of criminal offenders; authorizes warrantless arrest of a person where there is probable cause of a public offense that makes the person removable from the United States

E-Verify: Requires use by public contractors; incentives via tax code for private employers to use

Public benefits: State agencies and localities must verify eligibility for federal, state, and local benefits

Other: Unlawful to transport an alien; conceal, harbor, or shield an alien

\footnotetext{
${ }^{1}$ This section draws on Morse, Johnston, et al. (2012).
} 


State/Legislation Key Provisions

Georgia

HB87

Enacted: May 2011

Effective: July 2011

Law enforcement: Authorized to determine immigration status where probable cause for a crime, including any traffic offense; authorized to enter into agreements with U.S. Departments of Justice and Homeland Security to enforce immigration and customs laws

E-Verify: Requires use by public contractors and subcontractors, private employers (phased in from 2011 to 2013)

Public benefits: Applicants must provide at least one secure and verifiable document and affidavit of lawful presence (as of July 2012)

Other: Unlawful to transport an alien; conceal, harbor, or shield an alien

\author{
Alabama \\ HB56 \\ Enacted: June 2011 \\ Effective: May 2012 \\ HB658 (amended HB 56) \\ Enacted: May 2012 \\ Effective: May 2012
}

\section{South Carolina}

S20

Enacted: June 2011

Effective: January 2012
Law enforcement: Must reasonably attempt to determine immigration status of persons involved in lawful stop, detention, or arrest; prohibits law enforcement from restricting enforcement of federal immigration laws

Documentation: Unlawful to fail to apply for or carry federally issued alien registration documents

Employment: Unlawful for unauthorized to apply for work, solicit work in a public or private place, or perform work as an employee or public contractor

E-Verify: Requires use by public contractors and subcontractors

$\mathrm{K}-12$ education: Schools are required to determine a student's immigration status and submit annual reports to the state

Higher education: Unauthorized cannot attend college or receive a state scholarship, grant, or financial aid

Public benefits: Unauthorized cannot receive state or local public benefits; exemptions for K-12 education, emergency health care, disaster or emergency assistance, prenatal care, child and adult protective services

Driver's license: Unlawful for unauthorized to apply for or renew a driver's license Other licenses: Unlawful for unauthorized to apply for or renew a motor vehicle license plate, business license, commercial license, or professional license

Voting: Proof of citizenship and residency required to vote

Other: Unlawful to transport an alien; conceal, harbor, or shield an alien

Law enforcement: Authorized to determine immigration status during lawful stop, detention, or arrest

Documentation: Unlawful to fail to apply for or carry federally issued alien registration documents

Employment: Unlawful for unauthorized to apply for work, solicit work in a public or private place, or perform work as an employee or public contractor

E-Verify: Requires use by all employers

Public benefits: Unauthorized cannot receive state or local public benefits; exemptions for emergency health care, disaster or emergency assistance, prenatal care, child and adult protective services

Rental housing: Unlawful to enter into a rental agreement if person knows or recklessly disregards the fact that the alien is unlawfully present

Other: Unlawful to transport an alien; conceal, harbor, or shield an alien

SOURCE: Morse, Johnston, et al. (2012).

NOTE: Provisions subsequently struck down by the courts or enjoined are listed in italics.

Prior to enacting its omnibus bill, Arizona had a history of restrictive legislation toward unauthorized immigrants, specifically in requiring the use of E-Verify (the voluntary online employment verification system operated by the U.S. Citizenship and Immigration Services), as well as restricting access to in-state tuition at public institutions of higher education. The most prominent component of the 2010 omnibus legislation pertained to the new authority granted to 
law enforcement to attempt reasonable determinations of immigration status for persons involved in a "lawful stop, detention, or arrest" (Morse, 2011). The law also provided for warrantless arrest when law enforcement had probable cause regarding an offense that would make the individual subject to deportation. Other components of the legislation required immigrants to apply for and carry federally issued immigration documents. Another key provision was to bar unauthorized immigrants from applying for work, soliciting work in a public place, or working as an employee or public contractor. Transporting, concealing, harboring, or shielding an alien also became unlawful.

The Beason-Hammon Alabama Taxpayer and Citizen Protection Act followed Arizona's lead, with an even farther-reaching package of policy changes (see Table 2.2). The original bill was enacted in June 2011 to be effective in May 2012. Follow-on legislation enacted in May 2012 (and effective that same month) changed some features of the original bill (e.g., a penalty for entering a rental agreement with an unauthorized person was dropped). Other features were made more restrictive. Table 2.2 reflects the provisions in the updated 2012 legislation. In addition to the law enforcement, documentation, employment, and transportation/harboring provisions similar to Arizona's law, the Alabama legislation

- required the use of E-Verify on the part of public contractors and subcontractors

- required schools to verify a student's immigration status

- prohibited unauthorized immigrants from attending college or receiving state financial aid

- prohibited unauthorized immigrants from receiving state or local public benefits

- prohibited unauthorized immigrants from applying for or renewing a new driver's license

- prohibited unauthorized immigrants from applying for or renewing a motor vehicle license plate, business license, commercial license, or professional license

- required proof of citizenship and residency to vote.

The legislation in Utah, Georgia, Indiana, and South Carolina - all enacted between March and June 2011 —had features similar to those in Arizona and Alabama's bills (see Table 2.2). All four states had provisions pertaining to law enforcement and public benefits. The required use of E-Verify on the part of indicated employers also was included in all but Utah's omnibus legislation. South Carolina also incorporated a provision making it unlawful to enter into a rental agreement with an unauthorized immigrant, either knowingly or with reckless disregard for the renter's immigration status (a provision that was part of Alabama's original bill).

The Arizona law faced legal challenges by the U.S. Department of Justice immediately after passage, and such challenges followed the passage of the other state omnibus bills, as well. Prior to the law's effective date, a U.S. district court ruling placed a partial injunction on several features of Arizona's law specific to immigration enforcement, documentation, and employment. Arizona's governor appealed to the U.S. Supreme Court. The Court's ruling in Arizona v. United States in June 2012 preempted three provisions of Arizona's law pertaining to law enforcement and employment: making it a crime to fail to apply for or carry federally issued alien registration 
papers; authorizing warrantless arrest in cases where there is probable cause to believe a deportable offense has been committed; and making it unlawful to solicit, apply for, or perform work (Lam and Morse, 2012). The Supreme Court ruling invalidated these same provisions in the other five state omnibus packages (see the entries in italics in Table 2.2). At the same time, the Supreme Court upheld the Arizona provision requiring law enforcement officers to determine immigration status during a lawful stop, detention, or arrest.

In the time since Arizona's omnibus law was passed in 2010, numerous other states have had omnibus legislation introduced, but none have been enacted besides the five other states listed in Table 2.2. In 2011, immediately on the heels of Arizona's law, 30 states introduced omnibus bills. By 2012, just five states (Kansas, Mississippi, Missouri, Rhode Island, and West Virginia) had introduced omnibus legislation, but no measures were enacted. In part, the pace of legislative activity slowed as states waited on the U.S. Supreme Court ruling handed down in June 2012. Other than amendments to Georgia's law in 2013, there has been effectively no push for further omnibus legislation.

\section{State-Level Specific Policies}

Although comprehensive omnibus immigration legislation has been the course of action in six states, other states have adopted an incremental approach, with legislation regarding specific policies that largely correspond to components of Alabama's comprehensive HB56. But as noted earlier, while the intent of the omnibus legislation and those related state laws that focus on specific provisions has been to place restrictions on unauthorized immigrants and discourage such immigration, other states have enacted laws that remove immigration status from consideration in such areas as access to in-state tuition for higher education and requirements for obtaining a driver's license, among other examples.

Table 2.3 provides a summary of the state legislation in several key domains, first listing the six states with omnibus legislation and shading their cells in dark orange, indicating the most restrictive laws toward unauthorized immigrants. The remaining columns in Table 2.3 focus on policies related to law enforcement, employment (specifically E-Verify), higher education (specifically in-state tuition and other aid), driver's licenses, and public benefits (specifically access to publicly subsidized prenatal care and children's health insurance). Cells that are shaded indicate a state with a specific policy: Dark orange indicates a restrictive policy toward unauthorized immigrants; dark purple indicates an unrestrictive policy. For some policies, there are somewhat less restrictive variants (light orange shading) or somewhat less unrestrictive variants (light purple shading). The year the policy became effective is indicated when that information is available. In some cases, the table notes when a policy shift occurred to or from a more or less expansive version of the restrictive or unrestrictive policy, or a reversal from an unrestrictive or restrictive policy. 
Table 2.3. State Immigration Policy Status as of June 2015

\begin{tabular}{|c|c|c|c|c|c|c|c|c|c|}
\hline State & $\begin{array}{l}\text { Omnibus } \\
\text { Legislation }\end{array}$ & $\begin{array}{l}\text { Immigration- } \\
\text { Related Law } \\
\text { Enforcement }\end{array}$ & \multicolumn{2}{|c|}{$\begin{array}{c}\text { Use of } \\
\text { E-Verify }\end{array}$} & \multicolumn{2}{|c|}{$\begin{array}{l}\text { Eligibility } \\
\text { for In-State } \\
\text { Tuition }^{\mathrm{a}}\end{array}$} & $\begin{array}{l}\text { Access to } \\
\text { Driver's } \\
\text { License }^{\text {a }}\end{array}$ & $\begin{array}{c}\text { Subsidized } \\
\text { Prenatal }^{\text {Care }}{ }^{a}\end{array}$ & $\begin{array}{l}\text { Subsidized } \\
\text { Child Health } \\
\text { Insurance }^{a}\end{array}$ \\
\hline Alabama & 2011 & 2011 & \multicolumn{2}{|c|}{2011} & \multicolumn{2}{|c|}{2011} & & & \\
\hline \multicolumn{10}{|l|}{ Alaska } \\
\hline Arizona & 2010 & 2010 & \multicolumn{2}{|c|}{2007} & \multicolumn{2}{|c|}{2006} & & & \\
\hline \multicolumn{10}{|l|}{ Arkansas } \\
\hline California & & & \multicolumn{2}{|c|}{2011} & 2001 & 2012 & 2013 & & \\
\hline Colorado & & & \multicolumn{2}{|c|}{2006} & 2006 & 2013 & 2013 & & \\
\hline Connecticut & & & & & \multicolumn{2}{|c|}{2011} & 2013 & & \\
\hline Delaware & & & \multirow{2}{*}{\multicolumn{2}{|c|}{2011}} & & & 2015 & & \\
\hline Florida & & & & & \multicolumn{2}{|c|}{2014} & & & \\
\hline Georgia & 2011 & 2011 & 2006 & 2011 & \multicolumn{2}{|c|}{2008} & & & \\
\hline Hawaii & & & & & \multicolumn{2}{|c|}{2013} & 2015 & & \\
\hline Idaho & & & \multicolumn{2}{|c|}{2009} & & & & & \\
\hline Illinois & & & \multicolumn{2}{|c|}{2009} & \multicolumn{2}{|c|}{2003} & 2012 & & \\
\hline Indiana & 2011 & 2011 & 20 & 11 & & & & & \\
\hline lowa & & & & & & & & & \\
\hline Kansas & & & & & & & & & \\
\hline Kentucky & & & & & & & & & \\
\hline Louisiana & & & 20 & 11 & & & & & \\
\hline Maine & & & & & & & & & \\
\hline Maryland & & & & & & & 2013 & & \\
\hline Massachusetts & & 2014 & & & & & & & \\
\hline Michigan & & & 20 & 12 & & & & & \\
\hline Minnesota & & & 20 & 11 & & & & & \\
\hline Mississippi & & & 20 & 08 & & & & & \\
\hline Missouri & & & 20 & 08 & & & & & \\
\hline Montana & & & & & & & & & \\
\hline Nebraska & & & 20 & 09 & & & & & \\
\hline Nevada & & & & & & & 2013 & & \\
\hline New Hampshire & & & & & & & & & \\
\hline New Jersey & & & & & & & & & \\
\hline New Mexico & & & & & & & 2003 & & \\
\hline New York & & & & & & & & & \\
\hline North Carolina & & & 2006 & 2011 & & & & & \\
\hline North Dakota & & & & & & & & & \\
\hline Ohio & & & & & & & & & \\
\hline Oklahoma & & & 20 & 07 & & & & & \\
\hline Oregon & & & & & & & \begin{tabular}{l|l|}
2013 & 2014 \\
\end{tabular} & & \\
\hline Pennsylvania & & & 20 & 12 & & & & & \\
\hline Rhode Island & & & 2008 & 2011 & & & & & \\
\hline South Carolina & 2011 & 2011 & 2008 & 2011 & & & & & \\
\hline South Dakota & & & & & & & & & \\
\hline Tennessee & & 2010 & 20 & 11 & & & & & \\
\hline Texas & & & 20 & 15 & & & & & \\
\hline Utah & 2011 & 2011 & 2008 & 2010 & & & 2005 & & \\
\hline Vermont & & & & & & & 2013 & & \\
\hline Virginia & & & 20 & 10 & & & & & \\
\hline Washington & & & & & 2003 & 2014 & 1993 & & \\
\hline West Virginia & & & 20 & 12 & & & & & \\
\hline Wisconsin & & & & & 2009 & 2011 & & & \\
\hline Wyoming & & & & & & & & & \\
\hline Legend: & & $\begin{array}{l}\text { restrictive tow } \\
\text { restrictive towa }\end{array}$ & $\begin{array}{l}\text { d unauth } \\
\text { d unauth }\end{array}$ & $\begin{array}{l}\text { orized } \\
\text { orized }\end{array}$ & & & $\begin{array}{l}\text { More unres } \\
\text { Less unres }\end{array}$ & 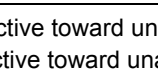 & $\begin{array}{l}\text { uthorized } \\
\text { thorized }\end{array}$ \\
\hline
\end{tabular}

SOURCES: Johnston and Morse (2012), Kostandini, Mykerezi, and Escalante (2013), Newman and Todd (2013), Teigen and Morse (2013), Morse (2014), Mathema (2015), Mendoza (2015), Mendoza and Ostrander (2015), Mendoza and Shaikh (2015), NCSL (2015a, 2015b), and National Immigration Law Center (NILC) (2015b).

NOTES: Year indicates the passage date for legislation or adoption date for other policies. Some laws or policies become effective in a later year or were phased in over time.

a Policies are specific to access by unauthorized immigrants. 
Our discussion of state policies primarily focuses on legislation in the key areas listed in Table 2.3. We do not cover the hundreds of state resolutions passed on issues related to immigration policy - affecting either authorized or unauthorized immigrants. ${ }^{2}$ Further, we do not address policy action at the substate level (e.g., cities or counties) that has proceeded in parallel during this period. In some cases, policies may be the subject of legal challenges and therefore stayed by a court injunction.

\section{Law Enforcement: Involvement in Interior Enforcement}

A central component of the six state omnibus laws discussed in the prior section was the codification of the role of state and local law enforcement officers in enforcing immigration laws as part of their regular duties. Prior to the omnibus laws, state involvement in federal immigration enforcement had expanded through the adoption of 287(g) programs, named for Section $287(\mathrm{~g})$ of the Immigration and Nationality Act, 8 USC 1357(g), which was added to the Illegal Immigration Reform and Immigrant Responsibility Act (IIRIRA) of 1996 (Waslin, 2010; Capps et al., 2011). Under Section 287(g), the U.S. Immigration and Customs Enforcement (ICE) can establish voluntary cooperative agreements with state and local authorities to permit local law enforcement, after receiving appropriate training, to perform immigration enforcement functions under the supervision of ICE. Programs were structured with a "task force" model where deputized officers may interrogate and arrest suspected noncitizens encountered in the field. The "jail enforcement" model allows deputized offers to interrogate noncitizens who have been arrested on local charges and then file immigration detainers if they are believed to be subject to removal. Detainees may be transferred to ICE custody and deportation proceedings ensue. Jurisdictions could adopt one, the other, or both models.

The Florida Department of Law Enforcement was the first to contract with ICE for a 287(g) program in 2002. The Arizona Department of Public Safety soon followed in 2003 (and the Department of Corrections was added in 2005). By 2010, ten states had agreements for one or both program models, and another 13 states had one or more county-level agreements (Kostandini, Mykerezi, and Escalante, 2013). ${ }^{3}$ Because of concerns about racial profiling, community safety, and other issues, the $287(\mathrm{~g})$ program was controversial from the outset (Waslin, 2010). Starting in 2012, ICE began scaling back the program, eliminating the task force model, in particular. ${ }^{4}$ Thus, as of June 2015, just two states continue to have active statewide

\footnotetext{
${ }^{2}$ The topics covered by the state resolutions tracked by the NCSL are wide-ranging. In many cases, state legislators are calling for federal action on major policy issues, such as comprehensive immigration reform; in other cases, the petitions reflect a narrow concern, such as assistance with specific types of visas or for specific immigrant groups. ${ }^{3}$ In addition to the state programs, numerous counties also entered into $287(\mathrm{~g})$ agreements with ICE (Kostandini, Mykerezi, and Escalante, 2013).

${ }^{4}$ The U.S. Department of Homeland Security (DHS) has introduced other "force multiplier" programs that integrate local law enforcement with federal immigration enforcement. For example, Secure Communities was activated on a county-by-county basis, starting in October 2008. Nationwide coverage was attained by January 2013 (Miles and Cox, 2014). Under Secure Communities, following an arrest, the Federal Bureau of Investigation background check performed by local law enforcement also returns information about immigration violations.
} 
287(g) agreements (jail enforcement model): Arizona and Massachusetts (ICE, undated). These states are shown with light orange shading in Table 2.3. The six states that adopted omnibus legislation are shown with darker shading to indicate the wider range of enforcement provisions under those laws compared with the 287 (g) program alone. Tennessee — which passed a 2010 law requiring standardized written procedure for verifying the citizenship status of individuals who are arrested, booked, or confined in a county or municipal jail or detention facility - is also shown in Table 2.3 in the lesser of the two restrictive groups.

\section{Employment: E-Verify and Other Status Verification Systems}

Four of the six omnibus bills, including Alabama's, have a provision mandating the use of the voluntary online federal E-Verify system to confirm whether a new employee is authorized to work in the United States. ${ }^{5}$ As of June 2015, this has been an active area of state policymaking (see Figure 2.1 and Table 2.3), involving 25 states either through legislation (22 states) or executive order (three states) (Mendoza and Ostrander, 2015). In 2006, Arizona was among the first group of states to legislate such a requirement, applying to all employers (shown in dark orange in Table 2.3 and Figure 2.1). Colorado, Georgia, and North Carolina adopted somewhat less-restrictive versions in the same year, where the E-Verify requirement applied to some or all public-sector employers, contractors, and sometimes subcontractors (shown in light orange in Table 2.3 and Figure 2.1). Other states followed in quick succession, most adopting the narrower employment verification requirement that applies just to the public sector or employers contracting with public entities. Several states - such as North Carolina, South Carolina, and Utah-initially enacted legislation that applied to public-sector employment and contractors, but later expanded the requirement to cover private-sector employers, as well. Rhode Island's policy was in place in 2008 by executive order, but rescinded in 2011 when a new governor came into office (Morse, 2012). Texas was the most recent state to enact an E-Verify law in 2015, specifically for state agencies.

Most laws have provisions for penalties for offending firms of varying size, although there is some evidence to suggest that compliance rates are well below 100 percent. ${ }^{6}$ For example, in Alabama, penalties include levying a fee or even the loss of a business license. When mandates apply to private employers, small firms are often excluded. Tennessee's law, for instance, excludes businesses with fewer than six employees. Other states, such as Indiana and Nebraska, require E-Verify for public-sector employers and contractors, but provide tax credits to privatesector employers who use E-Verify as a way to increase the voluntary use of employment verification. In some states, the required use of E-Verify was phased in over time, starting with larger employers and gradually including smaller businesses. Mandating the use of the voluntary

\footnotetext{
5 Starting in 2009, the federal government mandated that certain federal contractors use the E-Verify system.

${ }^{6}$ For example, Norwrasteh and Harper (2015) show that the compliance rate (estimated by the number of E-Verify queries as a percentage of new hires) in states such as Alabama, Arizona, Mississippi, and South Caroline is in the rage of 50 to 59 percent.
} 
federal E-Verify system and the imposition of penalties for failing to do so has been upheld by a 2011 U.S. Supreme Court ruling in a case that challenged Arizona's broad-based E-Verify law, punishable by suspension or revocation of the employer's business license (Morse, 2011).

Two states stand in contrast to those that have moved to require verified work authorization. In 2009, Illinois became the first state to limit the use of E-Verify explicitly on the part of employers. California followed in 2011. California's law prohibits municipalities from requiring the use of E-Verify except when required by federal law or required to obtain federal funds. In the 26 other states without an explicit policy as of mid-2015 either expressly requiring E-Verify or limiting its use, employers are presumably free to use the voluntary system or not.

Other employment-related legislation concerns the ability of unauthorized immigrants to work in specific fields that require licenses or certification. For example, in support of immigrants, Florida passed legislation in 2014 allowing certain unauthorized immigrant students to practice law under specific circumstances.

Figure 2.1. Status of State E-Verify Policy as of June 2015

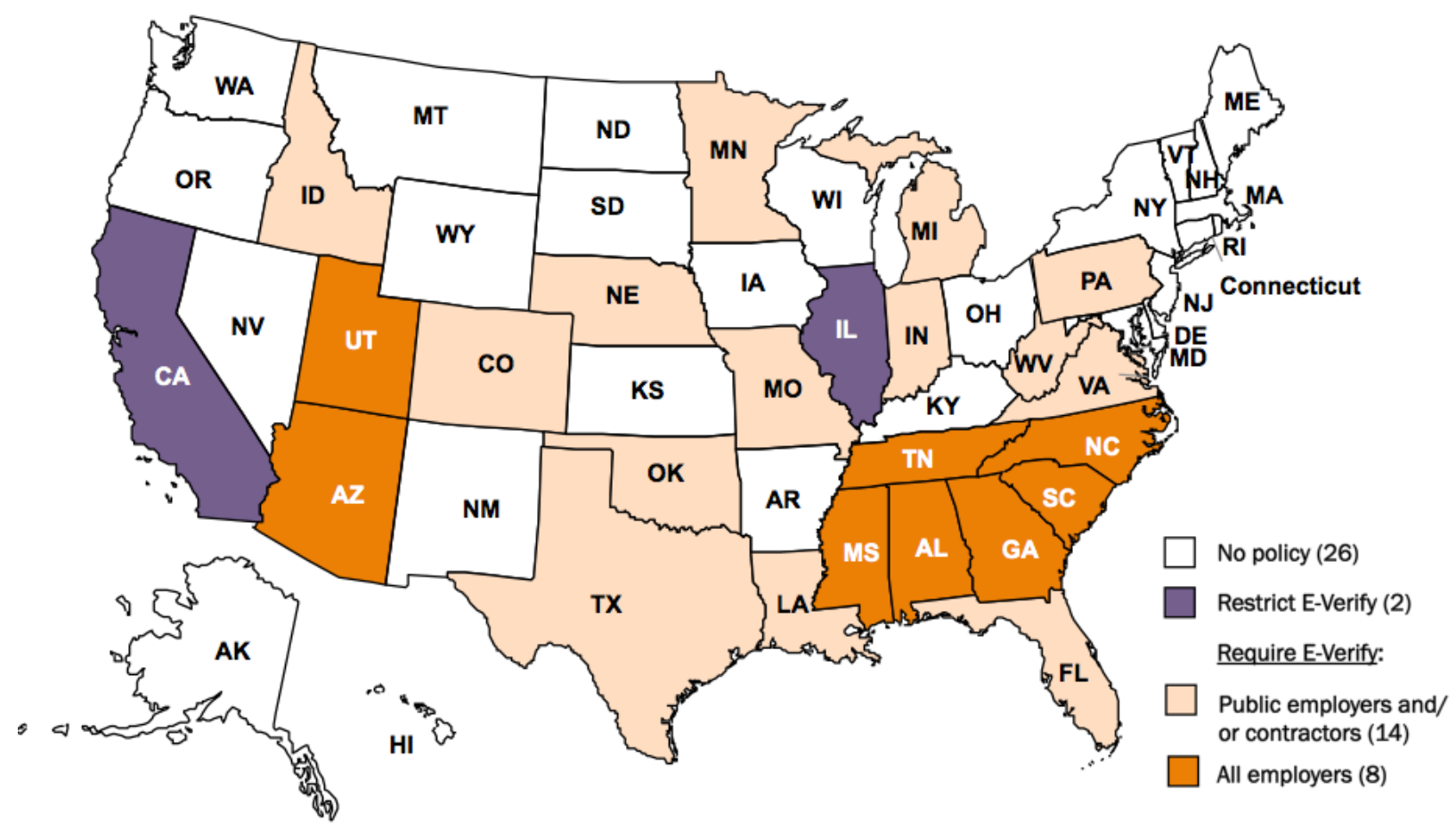

SOURCES: Johnston and Morse (2012), Newman and Todd (2013), Mendoza and Ostrander (2015), and NCSL (2015a, 2015b). 


\section{Higher Education: Eligibility for In-State Tuition and Other Financial Aid}

The Plyler v. Doe Supreme Court ruling (1982) provided for access to public primary and secondary education regardless of immigration status. Thus, there has been little scope for state policymakers to limit this public benefit for unauthorized children (the provision in Alabama's omnibus legislation notwithstanding). However, access to public higher education, and especially the discounted tuition rate available to those who meet state residency requirements, has been an area of active legislation (Pérez, 2014; Mendoza and Shaikh, 2015). The issue first came to the fore following the 1996 IIRIRA, which placed restrictions on state residency requirements for purposes of determining access to higher education in-state tuition and other forms of financial aid. Specifically, IIRIRA prohibited states from allowing unauthorized immigrants access to postsecondary benefits based on residency unless the same benefits were made available to any U.S. citizen or national. Although there has been disagreement over the congressional intent of the provision, the legislation effectively prevented 50,000 to 65,000 unauthorized immigrant students who otherwise met state residency requirements from being able to receive in-state tuition each year (Morse, 2014). Since that time, state legislation has focused on whether unauthorized immigrants are eligible for in-state tuition - and, if so, the associated residency requirements. Access to other forms of state financial aid, such as scholarships and loans, also has been a consideration.

As of mid-2015, 20 states had passed legislation, adopted policy through the state board of regents, or passed a ballot resolution removing legal status from consideration in accessing instate tuition (light purple shading of the cells in Table 2.3) or both tuition and other financial supports (dark purple shading in Table 2.3; see also Figure 2.2). Texas was the first state to pass such legislation in 2001, followed closely thereafter by California, Illinois, New York, and Utah in 2002 or 2003. Florida joined the ranks most recently, in 2014. In 2012, California extended other forms of financial aid to students regardless of immigration status. Minnesota's 2013 law covered both tuition and financial aid, while Washington did the same in 2014 for its state-funded needs-based grants. Texas and New Mexico also provide access to the full range of subsidies (discounted tuition, scholarships, and other financial aid). Colorado's 2013 legislation granting instate tuition access for unauthorized immigrants reversed legislation from 2006 restricting such access. Wisconsin allowed access to in-state tuition for unauthorized immigrants in 2009, but the law was revoked two years later. Typically, these state policies granting in-state tuition access require immigrants to graduate from state high schools and have resided in the state two to three years. Some states also require an affidavit promising to pursue legal status. Several states, such as Florida and Tennessee (not otherwise shown in Table 2.3 or Figure 2.2), explicitly prohibit consideration of parents' immigration status in determining residency of U.S. citizen dependent children enrolled in higher education, largely to protect U.S. citizen children whose parents are unauthorized. 
Figure 2.2. Status of State In-State Tuition Policy as of June 2015

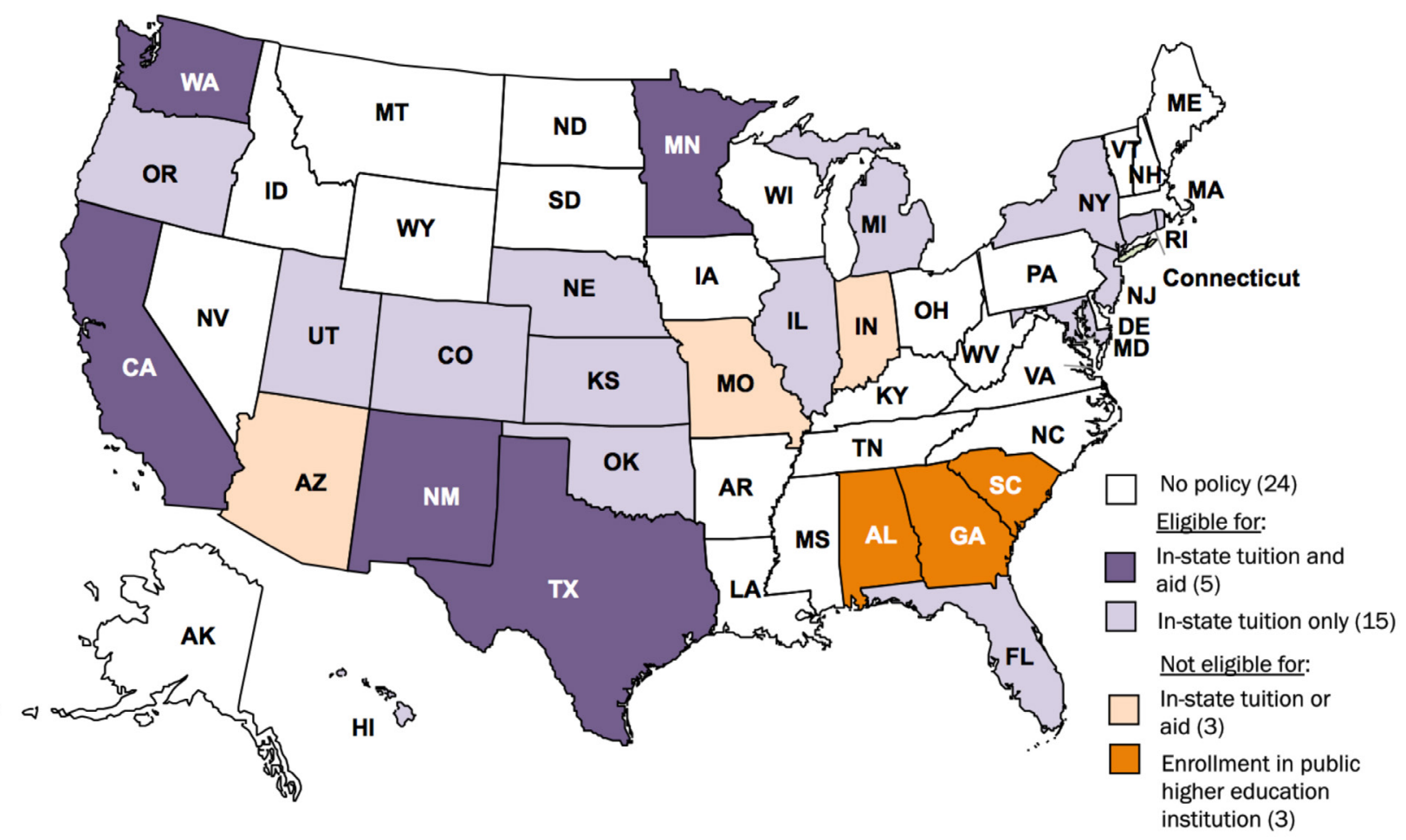

SOURCES: Morse (2014), Mendoza and Shaikh (2015), and NCSL (2015a, 2015b).

In contrast, just three states as of mid-2015-Arizona, Indiana, and Missouri-had adopted legislation or passed a ballot initiative explicitly disallowing unauthorized immigrants from accessing in-state tuition rates or other financial aid (light orange shading in Table 2.3 and Figure 2.2), effectively affirming the status quo under IIRIRA. For example, Arizona's Proposition 300 was approved by the voters in late 2006, making it one of the first states to explicitly restrict access to in-state tuition or financial aid funded or subsidized by state monies. In addition, three states-Alabama (as part of its 2011 omnibus legislation), Georgia (for the 35 institutions in the University System of Georgia), and South Carolina — prohibit unauthorized students from enrolling in state-funded higher education institutions, which amounts to an even stronger limitation on higher education access on the part of unauthorized immigrants (dark orange shading in Table 2.3 and Figure 2.2).

In June 2012, the Obama administration, through executive action, created the Deferred Action for Childhood Arrivals (DACA) program, which granted lawful presence and permission to work lawfully for unauthorized immigrants who arrived in the United States as children and met other criteria regarding age of arrival, current age, residency, education or military service, and contact with the criminal justice system (NILC, 2015a). Thereafter, several states made DACA recipients eligible for in-state tuition at all or some public higher education institutions (Pérez, 2014). However, since this is not a policy that applies to all unauthorized immigrants, Table 2.3 and Figure 2.2 do not identify such states. These states include Virginia, Mississippi, 
and Ohio, which otherwise did not grant or exclude access to in-state tuition for unauthorized students (i.e., they are among the states without shading in Table 2.3 and Figure 2.2). Of the six states with restrictive policies on either in-state tuition or enrollment (states with orange shading), Alabama, Arizona, and Missouri have made an exception for those with DACA status.

\section{Identification: Driver's License Eligibility and Other Requirements}

Alabama's 2011 omnibus immigration bill included a provision that effectively prohibited unauthorized immigrants from receiving a state-issued driver's license (Teigen and Morse, 2013; Mendoza, 2015). Arizona, Arkansas, and Virginia adopted similar limitations in the same year. Prior to those explicitly restrictive laws, with a few exceptions, most states had de facto policies that made unauthorized immigrants ineligible for state-issued driver's licenses (Pew Charitable Trusts, 2015). Starting with Washington in 1993, several states began issuing driver's licenses to unauthorized immigrants (shown with dark purple shading in Figure 2.3), typically based on birth certificates or passports issued by a foreign country as proof of identity, a tax identification number in lieu of a Social Security number, and a home utility bill or other evidence as proof of residency. Utah became the second state to adopt this policy in 2005, although it issued a drivingprivilege card that was not an acceptable form of identification. New Mexico joined their ranks in 2011 , followed by Illinois in 2012. A flurry of legislation in seven other states in 2013 continued

Figure 2.3. Status of State Driver's License Policy as of June 2015

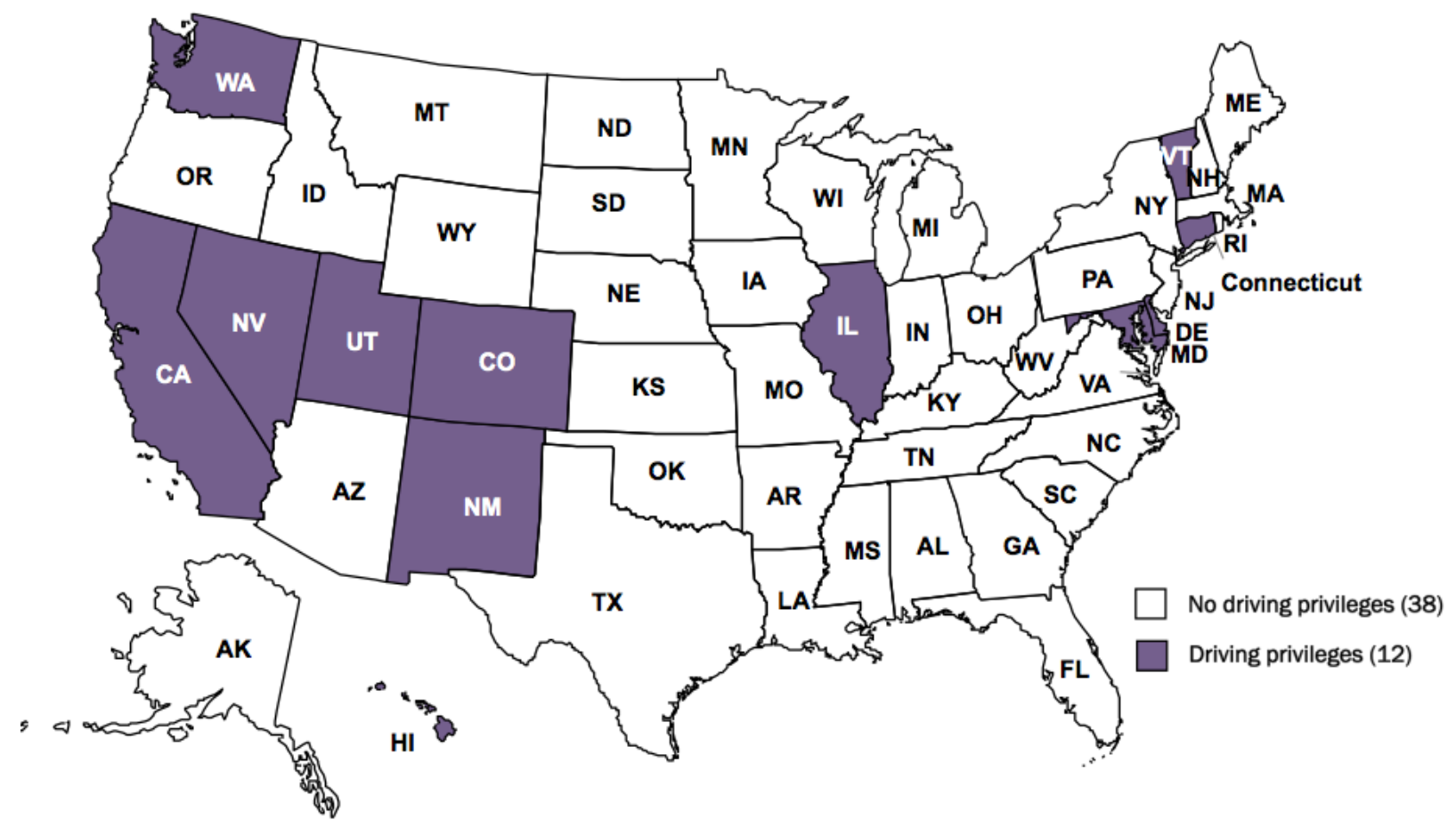

SOURCES: Teigen and Morse (2013), Mathema (2015), Mendoza (2015), and NCSL (2015a, 2015b). 
the trajectory of supporting the issuance of driver's licenses to unauthorized immigrants. (Oregon's law enacted in 2013 was suspended by voter approval of a 2014 ballot measure.) Delaware and Hawaii added laws in 2015. Other states, such as Florida, New Jersey, North Carolina, and Wisconsin, have actively debated providing access to driver's licenses for unauthorized immigrants (Mathema, 2015). ${ }^{7}$

Supporters of these bills have argued that licensed drivers were more likely to be insured and had a safer driving record. The use of licenses that did not serve as identification further addressed the stricter federal requirements for government-issued licenses and identifications under the REAL ID Act. ${ }^{8}$ This two-tier system would mean that some state-issued licenses would not be acceptable forms of federally authorized identification (e.g., required in order to board an airplane).

More recently, following the creation of the DACA program, states have differed in whether they would issue licenses to DACA immigrants. ${ }^{9}$ Both Arizona and Nebraska have governorissued executive orders announcing that they would not issue driver's licenses to DACA-qualified persons, while other states have declared their intention to provide licenses for this group. For authorized immigrants, a number of states (e.g., Georgia) have adopted the policy of making valid dates of the license to coincide with the period that the immigrant is authorized to be in the United States. This ensures that access to a valid driver's license does not extend past the period that the immigrant is authorized to be resident.

\section{Health Care: Access for Pregnant Women and Children}

With the passage of the 1996 federal Welfare Reform Act (formally the Personal Responsibility and Work Opportunity Reconciliation Act, or PRWORA), unauthorized immigrants were no longer eligible for publicly subsidized health insurance and health care for low-income families, although they still remained eligible for emergency Medicaid care, including labor and delivery. More generally, the provision of emergency care is required under the federal Emergency Medical Treatment and Active Labor Act of 1986.

States may counter the limitation on nonemergency coverage for unauthorized immigrants in one of two ways (Pew Charitable Trusts, 2014b). Since 2002, a regulatory policy under the Children's Health Insurance Program (CHIP) allows states to use federal CHIP funds to cover the prenatal care of a low-income pregnant woman. The logic of the coverage, known as the "unborn child option," is that since the child will be a citizen if born in the United States, the prenatal care is effectively for the presumptive citizen child. For this reason, some states limit the types of

\footnotetext{
${ }^{7}$ In addition to the state policies regarding driver's license access, Mathema (2015) discusses steps taken by a number of cities and municipalities to make identification cards available regardless of immigration status.

${ }^{8}$ The REAL ID legislation (2005) set forth a series of strict federal standards regarding state-issued driver's licenses and identification cards to make them more secure in the wake of the September 11,2001, terrorist attacks.

${ }^{9}$ As with in-state tuition policy, Table 2.3 and Figure 2.3 do not identify variation in state policy with respect to the treatment of DACA beneficiaries.
} 
prenatal care covered to those services directly of benefit to the unborn fetus. State funds also may be used to provide this coverage if the state passes a law affirming the extension of eligibility to unauthorized immigrants.

As of mid-2015, 17 states (see Table 2.3 and Figure 2.4) provided such coverage (NILC, 2015b). ${ }^{10}$ Only New Jersey and New York rely exclusively on state funds for this purpose. Indeed, New York was one of the first states to adopt this coverage option in 2002. Table 2.3 also notes that a handful of states extend publicly subsidized health insurance coverage for unauthorized children under age 19 if they otherwise qualify based on low family income. With one exception, these states also offer subsidized prenatal care. For qualifying unauthorized children in Florida and New Jersey, the family is required to pay the full premium cost of the public health insurance program. In the other states listed in Table 2.3, health insurance coverage for low-income children is available at the same subsidy rate regardless of immigration status.

Figure 2.4. Status of State Subsidized Health Care Policy as of June 2015

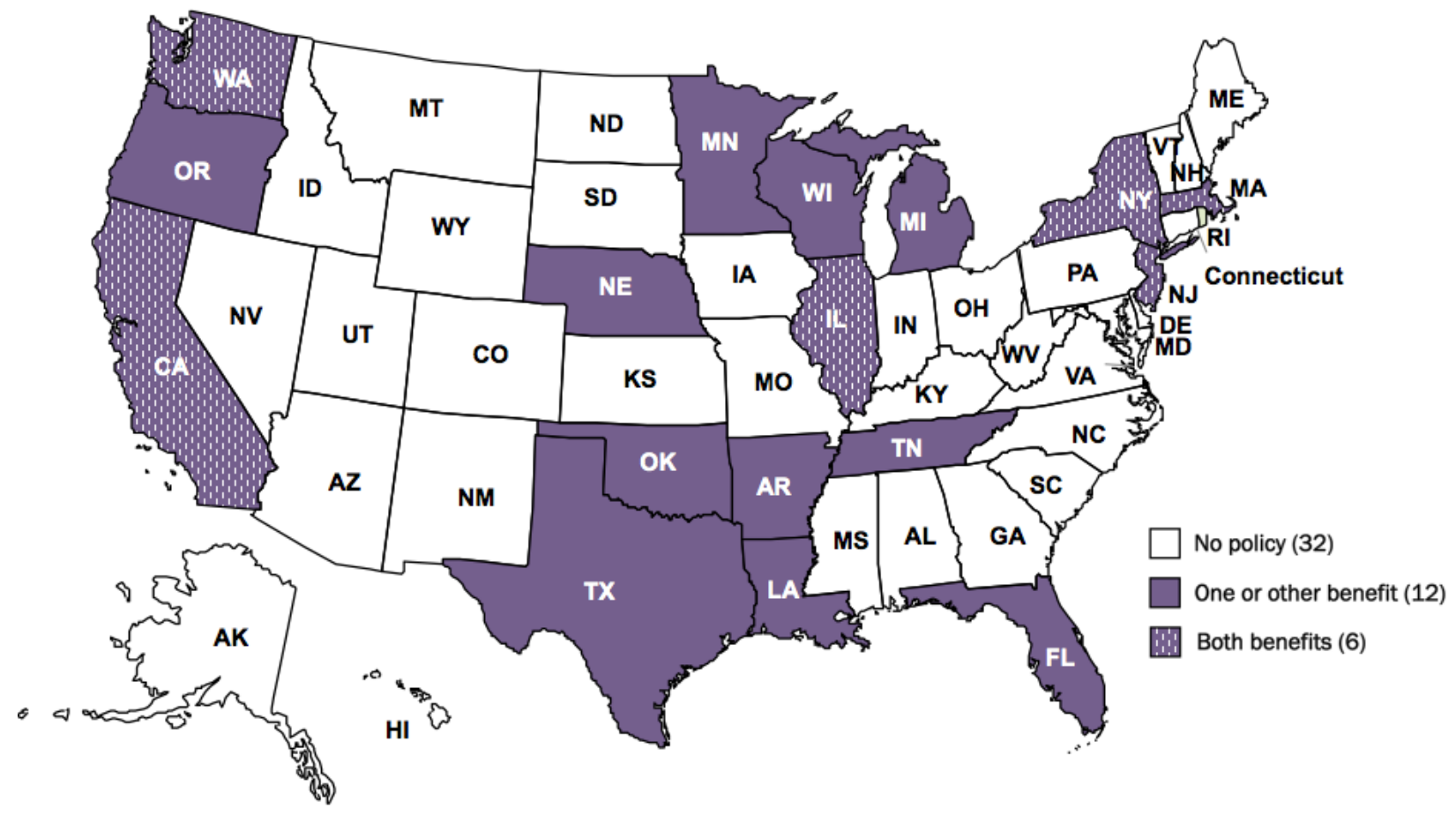

SOURCES: NCSL (2015a, 2015b) and NILC (2015b).

\footnotetext{
${ }^{10}$ The adoption or effective date for state-specific policies regarding access to subsidized prenatal care and subsidized health insurance for children are not as well documented, partly because they are not always associated with legislative action. For this reason, Table 2.3 does not show a year for the policies in the last two columns.
} 


\section{Summary of State Policies}

In the policy areas summarized in Table 2.3 , it is clear that states have been actively setting a course over the past decade or more with respect to unauthorized immigration. The omnibus legislation adopted in six states between 2010 and 2011 provide examples of a package of policies that placed restrictions on unauthorized immigrants in many aspects of daily life. But in the case of Utah, state policy did not maintain a consistent restrictive posture. Like a number of other states, Utah allowed unauthorized students access to in-state tuition and has made provisions for access to driver's licenses regardless of immigration status. Indeed, the tide of legislation in 2013 and 2014 has been to adopt unrestrictive policies toward unauthorized immigrants, in contrast with the wave of restrictive legislation around 2010 to 2012 (NILC, 2013).

Figure 2.5 summarizes the status of each state as of June 2015 with respect to the combination of state-level immigration policies in the following key areas: omnibus legislation, law enforcement, EVerify, in-state tuition, and driver's licenses. States with one or two policies in the restrictive direction are shaded light orange, while those with three or more restrictive policies are shaded dark orange. Light and dark purple shading are used in the same way to denote unrestrictive policies. The brown shading is used for those states that have a mixture of restrictive and unrestrictive policies.

Figure 2.5. Summary Status of State Immigration Policy as of June 2015

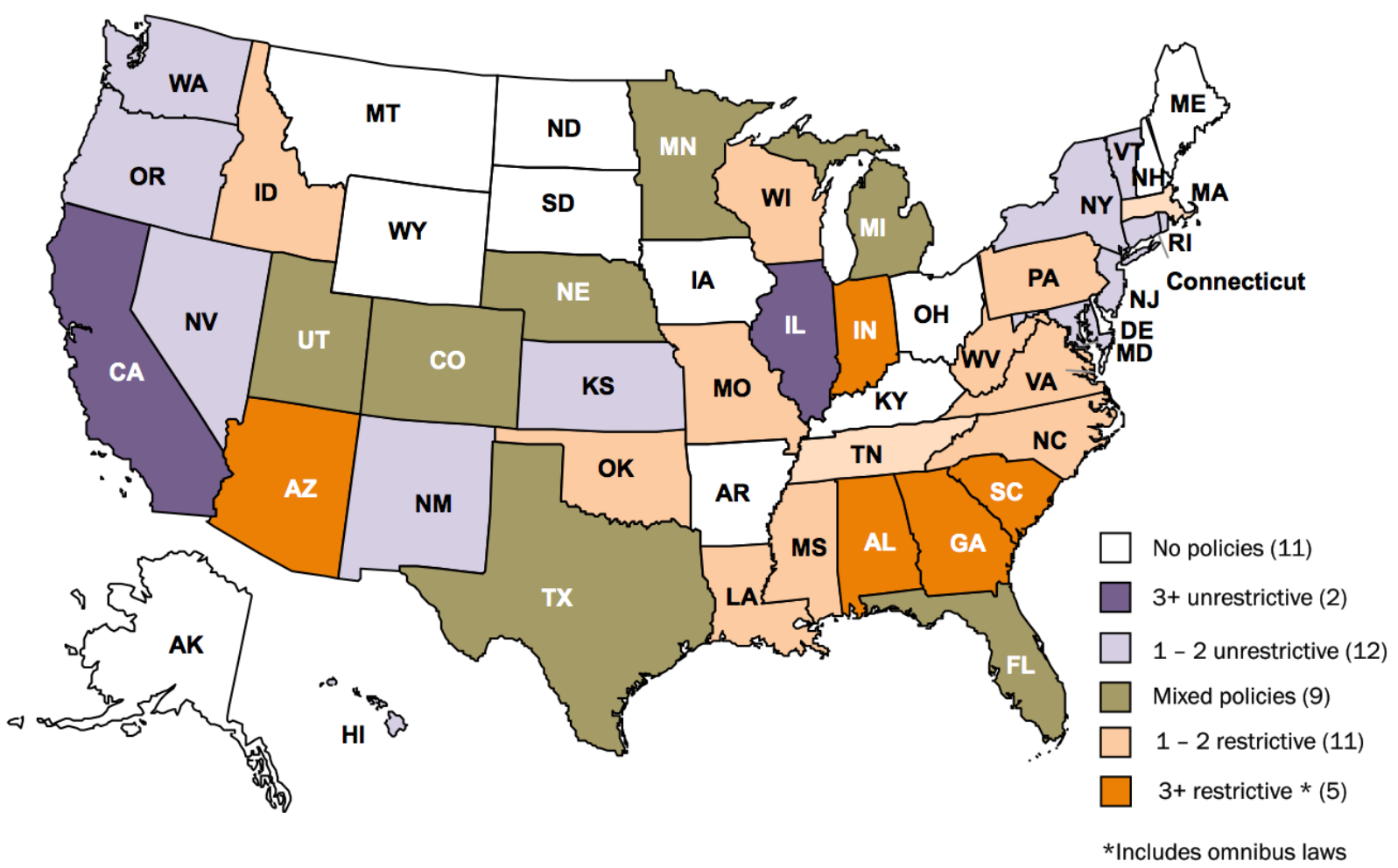

SOURCES: Johnston and Morse (2012), Kostandini, Mykerezi, and Escalante (2013), Newman and Todd (2013), Teigen and Morse (2013), Morse (2014), Mathema (2015), Mendoza (2015), Mendoza and Ostrander (2015), Mendoza and Shaikh (2015), NCSL (2015a, 2015b), and NILC (2015b). 
Overall, five states are shown as consistently restrictive across multiple policies (Alabama, Arizona, Georgia, Indiana, and South Carolina), while another 11 have one or two such restrictive policies in place. In the other direction, 14 states have adopted at least one or more of the unrestrictive versions of the policies, with just two of those states (California and Illinois) having unrestrictive policies in three areas: E-Verify, in-state tuition, and driver's licenses. Another nine states have a mixture of policies, typically a restrictive version of E-Verify but an unrestrictive version of in-state tuition or driver's license access. Eleven states have not adopted any variant of the policies under consideration as of mid- 2015 .

Although a comprehensive political analysis of the course of state-level immigration policy is beyond the scope of this study, it is worth noting that there are several distinct patterns in Figure 2.5. As of 2012, 60 percent of unauthorized immigrants lived in California, Florida, Illinois, New Jersey, New York, and Texas (Passel and Cohn, 2014). With the exception of Florida and Texas, which have a mixture of policies, the other four top-receiving states have adopted one or more policies that are unrestrictive toward unauthorized immigrants. In contrast, in three of the four states with the most-restrictive policies-Alabama, Indiana, and South Carolina-foreign-born residents make up fewer than 5 percent of the population, well below the national average of 13 percent and the top share in California of 27 percent (Brown and Patten, 2014). The restrictive policies tend to be concentrated in traditionally Republican states in the South and Mountain states, while the unrestrictive policies tend to be in place in traditionally Democratic states in the West, Midwest, North Atlantic, and New England. State political affiliation is not deterministic, however, as "red" states, such as Texas and Kansas, have each adopted one unrestrictive policy, while "blue" state Pennsylvania has adopted one restrictive policy. 



\section{Framework for Analyzing State-Level Immigration Policies}

In this chapter, we develop a cost-benefit framework for understanding the potential impacts of the most common types of state-level immigration policies, as categorized in the previous chapter. The framework relies on determining the set of effects (also referred to as impacts or outcomes) that a policy may have and how those effects create benefits (or costs) for different stakeholders. This framework then becomes the basis for undertaking formal cost-benefit analysis (CBA) of state-level immigration policies, where that analysis would take the viewpoint of the public-sector costs and benefits or the more general viewpoint of society as a whole. For purposes of this study, this chapter focuses on the cost-benefit framework we developed. The next chapter uses the framework to assess existing CBAs of state-level immigration-related policies.

We begin with an overview of our approach. We then discuss the set of expected outcomes associated with the following key policies: immigration-related law enforcement; E-Verify or other status verification systems; restrictive omnibus legislation; in-state tuition and other financial aid; driver's license eligibility; and health care access for pregnant women and children. As part of developing the framework for each policy, we also review the relevant empirical literature to assess the potential magnitudes of the expected effects and identify gaps where little is known about likely outcomes. Finally, we summarize the results of the cost-benefit framework for each policy in terms of the expected outcomes and which stakeholders will be affected.

\section{Overview of Approach}

Our goal in developing a framework of costs and benefits of state-level immigration policies is to complete a matrix such as the one illustrated in Table 3.1. For a given state-level immigration policy, we would first identify the expected impacts (the rows) and, for each impact, determine the expected effect for each of the relevant stakeholder groups (the columns). Drawing on theory and existing empirical evidence, each cell in the matrix would provide a predicted impact for the given outcome and stakeholder, ideally both the expected direction of the effect and the expected magnitude.

Table 3.1. Illustrative Matrix of Impacts by Stakeholder for a Given Policy

\begin{tabular}{lccccc}
\hline Impacts & Stakeholder $\mathbf{1}$ & Stakeholder $\mathbf{2}$ & Stakeholder $\mathbf{3}$ & Stakeholder $\mathbf{4}$ & Stakeholder 5 \\
\hline Impact 1 & $?$ & $?$ & $?$ & $?$ & $?$ \\
Impact 2 & $?$ & $?$ & $?$ & $?$ & $?$ \\
Etc. & & & & \\
\hline
\end{tabular}




\section{Policy Focus and Evidence of Impacts}

As shown in Table 3.2, our analysis focuses on either immigration policy as a bundle (e.g., omnibus legislation) or the five specific state-level policies regarding unauthorized immigrants that have been most active in the past decade: immigration-related law enforcement; E-Verify or other status verification systems; in-state tuition and other financial aid; driver's license eligibility; and health care access for pregnant women and children. For each policy, Table 3.2 specifies the status quo and then the dominant alternative policy that states have adopted. ${ }^{1}$ The table also indicates that the policy alternative is restrictive toward unauthorized immigrants relative to the status quo in the case of omnibus legislation, law enforcement, and E-Verify. For the other three policies, the alternative is unrestrictive. We note that we develop the cost-benefit framework focusing on single policies—some

\section{Table 3.2. State Immigration Policies Included in Cost-Benefit Framework: Status Quo, Policy Alternative, and Direction of Change}

\begin{tabular}{|c|c|c|c|}
\hline Policy & Status Quo & Policy Alternative & $\begin{array}{l}\text { Direction of } \\
\text { Change }\end{array}$ \\
\hline $\begin{array}{l}\text { Omnibus } \\
\text { immigration } \\
\text { legislation }\end{array}$ & $\begin{array}{l}\text { State has no express policy } \\
\text { regarding immigration-related law } \\
\text { enforcement, use of E-Verify or } \\
\text { other status verification systems, } \\
\text { in-state tuition, driver's license, } \\
\text { access to public benefits }\end{array}$ & $\begin{array}{l}\text { State places multiple restrictions on } \\
\text { unauthorized immigrations in such } \\
\text { domains as law enforcement, } \\
\text { employment, higher education, driver's } \\
\text { licenses, and access to public benefits }\end{array}$ & $\begin{array}{l}\text { Restrictive toward } \\
\text { unauthorized } \\
\text { immigrants }\end{array}$ \\
\hline $\begin{array}{l}\text { Immigration- } \\
\text { related law } \\
\text { enforcement }\end{array}$ & $\begin{array}{l}\text { State has no express policy to } \\
\text { enforce federal immigration policy }\end{array}$ & $\begin{array}{l}\text { State prohibits law enforcement from } \\
\text { restricting enforcement of federal } \\
\text { immigration laws }\end{array}$ & $\begin{array}{l}\text { Restrictive toward } \\
\text { unauthorized } \\
\text { immigrants }\end{array}$ \\
\hline $\begin{array}{l}\text { E-Verify or } \\
\text { other status } \\
\text { verification } \\
\text { systems }\end{array}$ & $\begin{array}{l}\text { Use of E-Verify by public and } \\
\text { private employers in the state is } \\
\text { voluntary }\end{array}$ & $\begin{array}{l}\text { Use of E-Verify is mandatory for all or } \\
\text { some subset of public and private } \\
\text { employers }\end{array}$ & $\begin{array}{l}\text { Restrictive toward } \\
\text { unauthorized } \\
\text { immigrants }\end{array}$ \\
\hline $\begin{array}{l}\text { In-state tuition } \\
\text { and other } \\
\text { financial aid }\end{array}$ & $\begin{array}{l}\text { State does not allow unauthorized } \\
\text { immigrants to receive in-state } \\
\text { tuition or other financial aid at } \\
\text { public colleges and universities for } \\
\text { which they otherwise qualify }\end{array}$ & $\begin{array}{l}\text { State allows unauthorized immigrants to } \\
\text { receive in-state tuition (and financial aid) } \\
\text { at public colleges and universities } \\
\text { provided they meet graduation, } \\
\text { residency, and other requirements }\end{array}$ & $\begin{array}{l}\text { Unrestrictive toward } \\
\text { unauthorized } \\
\text { immigrants }\end{array}$ \\
\hline $\begin{array}{l}\text { Driver's license } \\
\text { eligibility }\end{array}$ & $\begin{array}{l}\text { Unauthorized immigrants are not } \\
\text { eligible for state-issued driver's } \\
\text { license }\end{array}$ & $\begin{array}{l}\text { Unauthorized immigrants are eligible for } \\
\text { state-issued driver's license }\end{array}$ & $\begin{array}{l}\text { Unrestrictive toward } \\
\text { unauthorized } \\
\text { immigrants }\end{array}$ \\
\hline $\begin{array}{l}\text { Health care } \\
\text { access for } \\
\text { pregnant } \\
\text { women and } \\
\text { children }\end{array}$ & $\begin{array}{l}\text { Unauthorized immigrants do not } \\
\text { qualify for publicly subsidized } \\
\text { health insurance or medical care }\end{array}$ & $\begin{array}{l}\text { Unauthorized pregnant women are } \\
\text { eligible for subsidized prenatal care } \\
\text { and/or unauthorized children are eligible } \\
\text { for publicly subsidized health insurance }\end{array}$ & $\begin{array}{l}\text { Unrestrictive toward } \\
\text { unauthorized } \\
\text { immigrants }\end{array}$ \\
\hline
\end{tabular}

\footnotetext{
${ }^{1}$ Under the status quo, the use of E-Verify is voluntary. As shown in Figure 2.1 in the previous chapter, 22 states have adopted a restrictive stance in mandating the use of E-Verify for some or all employers, whereas only two states have taken the opposite position and prohibited the use of E-Verify. Thus, we consider the former to be the policy alternative of interest. The expected effects of a less restrictive E-Verify policy would be the opposite of the effects we discuss.
} 
restrictive and some unrestrictive - as well as restrictive omnibus legislation. Table 2.3 in the previous chapter demonstrates that many states have adopted policies in combination that contain both restrictive and unrestrictive components. The combined effects of adopting multiple policies may differ from a simple sum of the constituent parts.

In terms of impacts (i.e., the rows of Table 3.1), Table 3.3 lists the demographic, economic, and social domains that may be affected by any given state-level policy. For example, a key objective of restrictive state-level immigration policies is to reduce the number of unauthorized immigrants in the state. Thus, the impact on the immigrant population in the state represents a key demographic outcome that is relevant to consider for all state-level immigration policies, including those that are unrestrictive. The demographic shifts could, in turn, have secondary economic impacts on state-level gross domestic product (GDP, or gross state product), as well as the labor market, such as the employment and earnings of subgroups of workers. Depending on the nature of the policy, other relevant domains of impact include the education sector, from preschool to grade 12, along with postsecondary education. With some policies, law enforcement and the criminal justice system may be affected, as well as social welfare services. Other domains of potential impact, depending on the policy, include population health and health care services, state and local budgets, and other residual categories such as implementation costs.

\section{Table 3.3. Domains of Potential Demographic, Economic, and Social Impact of State Immigration Policies}

\begin{tabular}{ll}
\hline Domain & Number of immigrants (unauthorized or authorized) \\
\hline State immigrant population & $\begin{array}{l}\text { Impacts to Address } \\
\text { State economic output }\end{array}$ \\
Labor market & $\begin{array}{l}\text { Employment and wages of subgroups of workers defined by education, } \\
\text { race/ethnicity, nativity, or other characteristics }\end{array}$ \\
P-12 education & $\begin{array}{l}\text { Use of educational services and education outcomes from preschool to } \\
\text { grade 12 }\end{array}$ \\
Higher education & $\begin{array}{l}\text { Use of public and private education institutions, including two-year } \\
\text { colleges and four-year colleges and universities }\end{array}$ \\
Law enforcement & $\begin{array}{l}\text { Allocation of resources across specific types of state and local law } \\
\text { enforcement activities }\end{array}$ \\
Criminal justice system & $\begin{array}{l}\text { Allocation of resources across specific types of criminal justice system } \\
\text { costs (e.g., courts, jails, prisons) }\end{array}$ \\
Social welfare system & $\begin{array}{l}\text { Specific cash and in-kind transfer programs (based on availability to } \\
\text { unauthorized immigrants) }\end{array}$ \\
Population health and & $\begin{array}{l}\text { Health outcomes (e.g., immunization rates, communicable diseases, } \\
\text { babies with low birth weight) and health care utilization (public and private } \\
\text { costs overall and for specific areas such as emergency rooms, substance } \\
\text { abuse treatment, and mental health services) }\end{array}$ \\
State and local budgets & $\begin{array}{l}\text { Specific sources of state and local tax revenues and expenditures } \\
\text { Costs to implement adopted policies and defend them in the courts }\end{array}$ \\
\hline
\end{tabular}


In reviewing the empirical research on the impact of state-level immigration policy, we limit our focus to studies using methods that support a causal interpretation. In general, experimental methods cannot be applied to study the causal effect of the immigration-related policies we examine in this report. Thus, researchers have employed a number of quasi-experimental designs to identify policy impacts. One of the most commonly used methods is difference-in-differences estimation. The popularity of this approach stems from the variation across states and over time in the policy environment. In effect, the change in the outcome of interest in states with the policy (the "treatment" states) is compared with the change in the outcome in states without the policy (the "control" states). Studies including multiple states estimate the average effect of adopting a specific policy. Some studies focus on a policy change in a single state, in which case the typical approach is to use synthetic control methods for comparative cases studies in which a weighted average of other states, selected to match the treatment state in the pretreatment period, serves as the counterfactual (Abadie, Diamond, and Hainmueller, 2010).

In terms of stakeholders (i.e., the columns of Table 3.1), our primary focus will be on those in the state adopting the policy. We define the following main groups and subgroups:

- $\quad$ private individuals

- unauthorized immigrants

- authorized immigrants (includes naturalized U.S. citizens) and native-born

- employers

- public sector

- state government

- local governments.

A parallel set of stakeholders would exist in other states outside the state adopting the policy, such as neighboring states or states elsewhere in the country.

Note that in defining our stakeholder groups, particularly for private individuals, we expand beyond the population group that is the primary target of the policies we consider-unauthorized immigrants - to include other population groups that may be affected, often in unintended ways. For example, such spillover effects can arise in mixed-status families, where one or both parents are unauthorized but some or all of their children are native-born U.S. citizens. Policies that are intended to affect the behavior of the unauthorized parent(s) may also have effects on their children, whether unauthorized themselves or U.S. citizens. Other examples include policies such as those related to law enforcement or employment that affect both unauthorized and authorized immigrants, or even the native-born, because the population subgroups are not readily distinguishable without further documentation. Such examples are discussed further in the context of specific state-level policies. 
With this basic approach established, we can discuss the expected policy effects and the existing empirical evidence. ${ }^{2}$ In terms of expected policy effects, we consider two broad domains of impact: (1) the effect on the number of unauthorized immigrants residing in the state (the first row in Table 3.2), an impact that we expect to apply, at least to some degree, to each of the statelevel policies we consider; and (2) the direct effect on all other relevant outcomes (the remaining rows of Table 3.2). Because the effect on the number of immigrants could apply to all policies, we discuss those potential consequences first. We then discuss each specific policy and the other expected impacts.

\section{Expected Effect of State-Level Policies on the Number of Immigrants}

A primary objective when states have enacted restrictive immigration policies is to reduce the number of unauthorized immigrants over the level that would have been experienced under the status quo, either because unauthorized immigrants in the state leave or because unauthorized immigrants who might have moved to the state do not arrive. Restrictive state-level policies may affect where unauthorized immigrants reside in both direct and indirect ways (Leerkes, Bachmeier, and Leach, 2013). Policies that identify and remove unauthorized immigrants through deportation are referred to as "territorial exclusion." Interior enforcement policies, as an example, would have a direct effect on the number of unauthorized immigrants in a given state to the extent that those policies lead to deportation of those who are not lawfully present in the United States (or those who are rendered subject to deportation because of certain actions, e.g., a criminal conviction).

A form of indirect exclusion is "social exclusion," whereby unauthorized immigrants are limited in the life chances and other social conditions they experience in any given location through restrictions related to the labor market, education, and other domains of public life. Forms of social exclusion include requirements that employers use E-Verify, and the inability of the unauthorized to access in-state tuition at public higher education institutions or obtain a driver's license. Like territorial exclusion, social exclusion would be expected to change the underlying desirability of being in any given location.

Another indirect mechanism is a deterrence effect in which restrictive policies deter migration to a state and push migrants to leave because expected earnings decrease or costs increase. The deterrence effect arises through an increased probability of deportation, a reduction in the likelihood of being employed, a decrease in earnings when employed, or an increase in living expenses (e.g., because of transportation limits, education costs, and so on). Conversely, by the same arguments, when states adopt unrestrictive policies toward unauthorized immigrants,

\footnotetext{
${ }^{2}$ A completed version of Table 3.1 would form the basis for a CBA. In the remainder of this chapter, we focus on developing the relevant rows and columns for the matrix and the corresponding cell entries. We do not explore the additional issues that arise in the use of a completed matrix for CBA, such as the choice of a discount rate or whether differential weights are applied to the benefits and costs for each stakeholder.
} 
it may lead to an increase in their numbers over the status quo because of more immigrants or fewer emigrants.

With both restrictive and unrestrictive policies, there also may be an effect on the location decision of authorized immigrants or other population subgroups, such as U.S. citizens with immigrant parents or grandparents. With restrictive policies, this spillover phenomenon is sometimes called a "chilling effect." With such policies, those who are authorized immigrants or U.S. citizens with an immigrant background may want to avoid a legal or social climate that may be perceived as hostile toward immigrants and therefore change their behavior in ways that mirror the responses of unauthorized immigrants. With unrestrictive policies, authorized immigrants or U.S. citizens may be attracted to communities that are perceived to be more welcoming and therefore also respond to the policy. If state immigration policies affect nontargeted authorized immigrants or U.S. citizens, the effects on population levels will be compounded, with even larger population declines in the case of restrictive policies or even larger population increases in the case of unrestrictive policies.

Whether a change in the number of unauthorized immigrants or other population groups is realized is an empirical question, and we discuss the evidence of the effects of state-level policies on immigrant levels later in this chapter. If a given policy has an impact on the number of unauthorized immigrants in the state, economic theory and previous literature suggest that changes in immigrant levels (or the size of the population more generally) may have secondary effects on key economic variables, including the wages of native-born workers, the level of economic output, tax revenues, and the use of public services, as well as important social outcomes, such as the level of crime. We discuss each of these areas of potential impact in turn. In doing so, for simplicity, we focus on the impact of a restrictive policy change that reduces the number of unauthorized immigrants. Similar effects would be expected if there were a decline in other subgroup populations. Unrestrictive policies that produce population gains would be expected to have the opposite effects as those we discuss here.

\section{Labor Market Impacts}

Based on a supply-and-demand framework, economic theory predicts that, under certain conditions, the outflow of immigrants from a state as a result of a restrictive policy will decrease the supply of labor and thus affect the wages of those workers whose skills are close substitutes. Because unauthorized immigrants disproportionately have less education and lower skill levels, we would hypothesize that a reduction in the number of unauthorized immigrants will be associated with an increase in the wages of lower-skilled native workers and authorized immigrants, provided they are close substitutes. However, a decrease in the supply of lowerskilled workers implies that, in relative terms, there is an increase in the supply of higher-skilled workers. Also, relative to the number of workers, there is an increase of capital. Consequently, theory predicts the opposite effect (i.e., a decrease) for the wages of higher-skilled workers and the return to capital. However, workers and capital can move with relative ease across state 
borders. This would tend to diminish the magnitude of any impact on local wages or return to capital. Therefore, we would expect the impact of changes in the number of unauthorized immigrants on wages to be lower at the state level than when such shifts in supply occur at the national level. In terms of the stakeholders represented by the columns in Table 3.1, it is evident that these labor market impacts would apply to unauthorized immigrants, authorized immigrants, and natives, as well as employers.

Ultimately, the impact of changes in labor supply on wages as a result of shifts in the number of unauthorized immigrants is an empirical question. Although theory can help us understand the expected direction of the effects of immigration on wages, it does not tell us anything about the magnitude of these effects. In Text Box 3.1, we summarize the empirical evidence more generally on the relationship between the supply of immigrants and wages of native workers. That body of research provides mixed evidence regarding the expected effects on wages, tied in part to the empirical and analytic methods employed, but which nonetheless generally finds relatively small effects.

\section{Text Box 3.1. Literature on Immigrants and Wages of Natives}

There is an extensive literature that empirically assesses the effects of immigrants in the United States on the wages of native-born workers, particularly those with less than a high school education. The theoretical expectation is that an influx of immigrants with less education than the average native-born worker will increase the supply of less-educated workers and put downward pressure on the wages of less-educated native workers with whom the immigrants would compete. Researchers have used various methods to measure the size of this potential effect, based on estimates for the United States as a whole, as well as specific local labor markets differentially affected by immigration.

Despite some mixed evidence, reviews of the literature as of the mid-1990s generally concluded that the effect of lower-skilled immigration on the wages of native workers was relatively small. For example, a review by Friedberg and Hunt (1995) indicated that a 10-percent increase in the proportion of immigrants in the population reduced native wages by 1 percent at most. The most plausible estimates identified by Smith and Edmonston (1997) suggested that the influx of immigrants starting in 1980 had reduced the wages of high school dropouts by about 5 percent, leading them to conclude that "immigration has had only a relatively small adverse impact on the wage and employment opportunities of competing native groups" (p. 7).

Research in the past 15 years has continued to provide mixed evidence. One set of studies used an "area approach," which consists of studying the effect of immigrants to particular geographic areas on wages in those areas (see, for example, the reviews by Longhi, Nijkamp, and Poot, 2005, and Okkerse, 2008). Such studies tend to find immigrants have null or small effects on native wages. This approach has been criticized, however, because of the mobility of capital and labor in response to immigration. For example, lower-skilled native workers may migrate out of a local labor market (or not migrate into the area) in response to an influx of immigrants (the empirical pattern analyzed in the past 20 years), which would then attenuate the negative effect on wages. Although Card (2009) acknowledges the limits of the cross-area 
approach, he concludes that "immigration over the past two or three decades has had only minor effects on the mean wage differences between natives in different skill groups ..."

Other studies have used national-level estimates with equally mixed findings, in part because of different estimates regarding the substitutability of immigrants for native workers, and of workers with different education levels. For example, Ottaviano and Peri (2012) conclude that, to a small degree, immigrants and natives within the same education and experience levels are imperfect substitutes but that high school dropouts and graduates are interchangeable (i.e., perfect substitutes). With these assumptions, they estimate smaller impacts of immigration between 1990 and 2006 on native high school dropouts (actually suggesting wage gains of 0.6 percent to 1.7 percent). In contrast, Borjas $(2013,2014)$ argues that immigrants and natives in the same education-experience groups are interchangeable, but high school dropouts and graduates are not. Using national level data through 2011, his results indicate a larger unfavorable relationship between changes in the supply of immigrants and the wages of nativeborn workers. His estimates indicate, for example, that a 10-percent increase in the size of a skill group (e.g., high school dropouts) resulting from immigration would reduce the weekly wages of men by 3.7 percent. The negative wage effects are somewhat larger for Hispanic men and somewhat smaller when men and women are combined. Based on these parameter estimates, Borjas $(2013,2014)$ simulates the effects of the influx of immigrants (authorized and unauthorized) during the two decades from 1990 to 2010. The increase in supply had the largest relative effect for high school dropouts, with an estimated wage impact equal to a 6-percent decline in the short run and a 3-percent decline in the longer run. Much of this adverse wage effect for high school dropouts is attributable to unauthorized immigrants. For workers with a high school degree or more education, the supply impacts of immigration are smaller, but the relative contribution of legal immigration is larger. Estimates from several other developed countries also show impacts in the 1- to 4-percent range, for a 10-percent change in the size of the workforce due to immigration (see, for example, Aydemir and Borjas, 2007, for Canada; Steinhardt, 2009, for Germany; and Bratsberg et al., 2014, for Norway).

The studies that use the "area approach" are likely to be more relevant to the study of statelevel immigration policies (as these are likely to affect immigration only locally). However, even among the group of area studies, there is no firm consensus on the magnitude of the effect of immigration on wages.

\section{Impacts on Economic Output}

If restrictive immigration policies have the effect of reducing the number of unauthorized immigrants in the state (or immigrants more generally), we would expect a corresponding decrease in economic output as measured by GDP. Furthermore, the total stock of capital could be reduced as capital migrates to states with higher marginal returns, leading to a further downward effect on economic output. Viewed in terms of output per capita, the effect is uncertain because total output has declined, but so has the total population. Thus, on a per capita basis, economic output may increase, decrease, or remain unchanged. It is also important to acknowledge that if unauthorized immigrants relocate to other states rather than leave the 
country, the impact on the economy at the national level effectively would be neutral, as the reduction in the labor input in one state is counterbalanced by an increase in another state.

Several studies have sought to quantify the expected loss in aggregate output if unauthorized workers were removed from the United States as a whole or a given state, with no provision for replacing those workers through expanded legal immigration. For the county as a whole, one estimate suggests the immediate effect would be annual lost output of about $\$ 650$ billion in 2007 dollars or about \$2,200 per capita (The Perryman Group, 2008). Estimates at the state level as part of the same study indicate lost GDP in the range of 7 to 13 percent for states that are more heavily dependent on unauthorized workers - such as Arizona, California, Nevada, Texas, and Florida - with corresponding declines in GDP per capita. A study for Texas estimated that the loss of the estimated 1.4 million unauthorized immigrants in the state would reduce GDP by a smaller amount, about 2.1 percent or nearly \$18 billion (in 2000 dollars) (Strayhorn, 2006). Such variation in estimates indicates the sensitivity to underlying modeling assumptions.

\section{Fiscal Impacts}

A decrease in the number of unauthorized immigrants would be expected to have an impact on state and local government budgets, as well. On the one hand, unauthorized immigrants contribute to government revenue through state and local taxes paid (e.g., sales, excise, property, and income taxes), and such tax collections would decline. On the other hand, there would be a reduction in the use of government services on the part of unauthorized immigrants, which would reduce government expenditures. The net effect on government budgets would depend on whether unauthorized immigrants, on balance, pay more into government coffers than the cost of the public services they consume. Again, this is an empirical question, and the net fiscal impact is likely to vary from state to state depending on the structure of the tax system and the publicsector goods and services available to unauthorized immigrants.

A number of studies have calculated the net fiscal impact of unauthorized immigrants at the state and local level. ${ }^{3}$ Although many such studies focus more on the revenue side or, alternatively, on the expenditure side, there are several examples that provide a more balanced look at the fiscal impact. ${ }^{4}$ Such estimates are predicated on a number of assumptions about the extent to which various taxes apply to unauthorized immigrants and the types of public benefits they qualify for or access. On the tax side, estimates typically account for sales and property taxes paid (the latter as owners or through landlords as renters), and assumptions are made about

\footnotetext{
${ }^{3}$ See, for example, Gardner, Johnson, and Wiehe (2015) for state-by-state estimates of the net fiscal impact of unauthorized immigrants. Other studies consider the net fiscal impact of immigrants at the state level more generally, including both those legally present in the United States and those that are unauthorized. See, for example, Gans (2008), Fennelly and Huart (2010), Commission to Study the Impact of Immigrants in Maryland (2012), and Appold et al. (2013).

${ }^{4}$ A Congressional Budget Office (CBO) study (2007) provides a review of the more rigorous studies that estimate the net fiscal impact of unauthorized immigrants on state and local budgets.
} 
the share of income that is "on the books" or reported when a state has an income tax. On the expenditure side - with the exception of $\mathrm{K}-12$ education and emergency medical care (or subsidized care for pregnant women and health insurance for children in those states that have those provisions, as illustrated in Table 2.3) — unauthorized immigrants are not eligible for most publicly funded goods and services provided at the state or local level (or at the federal level, either). Costs to the criminal justice system when unauthorized immigrants commit crimes or require protection from criminal activity are relevant, however. Thus, state and local expenditures related to education, health care, and law enforcement are most often the focus of fiscal impact estimates for the unauthorized population.

Among recent studies making such comprehensive calculations, unauthorized immigrants are estimated to cost state and local governments more than they contribute in Iowa (Pearson and Sheehan, 2007) and Mississippi (Bryant, 2006), while the reverse is found in Texas (Strayhorn, 2006). Estimates for Colorado (Fairley and Jones, 2011) suggest that expenditures on unauthorized immigrants related to education, health care, and law enforcement are nearly equal to their contributions in taxes. Studies of Missouri (Ehresman, 2006) and New Mexico (New Mexico Fiscal Policy Project, 2006) estimate that taxes paid by unauthorized immigrants outweigh the costs to provide public education for their children (by far the largest cost component in the studies for Colorado, Iowa, Mississippi, and Texas cited above), but they do not account for costs in other sectors, such as health care and law enforcement.

While these studies are informative, the net fiscal impact of unauthorized immigrants in one state cannot be generalized to other states, as noted by CBO (2007), given differences in the composition of the population of unauthorized immigrants, variation in the structure of taxes, and the types and costs of public-sector goods and services consumed. Moreover, estimates of net fiscal impact at a point in time (for a given fiscal year, for example), do not account for the time path of expenditures versus tax receipts for unauthorized immigrants. Over a lifetime, unauthorized immigrants may start out as net recipients of government spending while young and schooling is under way, then shift to being net contributors once adulthood is reached and work life begins.

\section{Other Potential Impacts from the Change in the Immigrant Population}

A reduction in the number of unauthorized immigrants could be expected to affect other domains beyond the economic impacts discussed thus far. One that has received attention in policy debates and the research literature is the relationship between immigration and crime. However, as summarized in Text Box 3.2, there is little empirical evidence to suggest that increases in the number of immigrants leads to a rise in crime (or, conversely, that a decrease in the number of immigrants would produce a reduction in crime). This is a robust finding across a number of studies using alternative data sources and methods. Given the absence of evidence suggesting a strong relationship between immigration and crime, we omit crime from consideration as a potential secondary impact from a reduction in the number of unauthorized immigrants. 


\section{Text Box 3.2. Literature on Immigration and Crime}

A body of empirical research has examined the relationship between immigration and crime in the United States (see Miles and Cox, 2014, for a recent review). The evidence from the studies with the most rigorous designs to capture causal relationships consistently find no statistically significant or policy relevant relationship.

One set of studies examines patterns of crime and immigration across communities. Reid et al. (2005), for example, study the impacts of immigrants on crime by conducting cross-section regressions of levels of immigration on crime rates, controlling for a large number of characteristics of the geographic area. They find that, once the other factors are controlled for in the regression framework, areas with more immigrants do not experience higher levels of crime. Lee, Martinez, and Rosenfeld (2001) examine three cities on the U.S.-Mexican border and find that within those cities, the areas with higher numbers of immigrants did not experience higher levels of crime.

Employing a similar approach, Butcher and Piehl (1998) find that, once demographic characteristics are held constant, urban areas with more immigrants tend to have lower crime rates. They also find that youth born abroad are less likely to commit crimes. Butcher and Piehl (2007) further document that recent immigrants are one-fifth less likely to be incarcerated than natives.

Wadsworth (2010) examines the increase in immigration between 1990 and 2000 and notes that it coincides with the reduction on violent crime in the United States. Using U.S. Census data and Uniform Crime Report data to investigate the link, the study indicates that areas with the largest increases in the numbers of immigrants experienced the largest reductions in homicide and robbery.

These studies must confront the same methodological issues faced by the research on the impact of immigration on wages; namely, that immigrants might be attracted to geographic areas with certain characteristics. By using non-U.S. (Italian) data, Bianchi, Buonanno, and Pinotti (2012) overcome this problem by using the number of immigrants to countries other than Italy as instrumental variables. They also find no significant effect of immigration on crime rates (although they do find a small effect on robberies). Chalfin (2014) uses rainfall in Mexico, which is related to the number of Mexicans who emigrate to the United States, as an instrumental variable and finds results that are consistent with a null effect of immigration on crime in the United States.

\section{Other Expected Effects of State-Level Policies}

Depending on the state immigration-related policy, we might expect a policy to have effects on other outcomes in addition to the direct effects on the number of unauthorized immigrants and the related secondary effects described above. In the sections that follow, we examine other potential areas of impact associated with each of our key policies of interest. For each policy, we present a summary table of potential main impacts and secondary impacts. Each table contains an initial row that corresponds to the expected main impact on the number of unauthorized immigrants and expected secondary impacts on wages, economic output, and fiscal impact discussed above. We then introduce expected primary and secondary impacts in other domains. 
As indicated in Table 3.2, in discussing law enforcement, E-Verify, and omnibus legislation, we are considering the effects of a state adopting a single policy or a bundle of policies that is restrictive with regard to unauthorized immigrants relative to the status quo. In the case of instate tuition, driver's license eligibility, and access to health care, we consider a policy alternative that is unrestrictive relative to the status quo. For each policy area, once we have considered the expected effects, we review evidence from empirical research to determine whether there is evidence of policy impact in the expected direction. Our discussion of each policy concludes with a summary of the cost-benefit framework in terms of a completed version of Table 3.1.

\section{Framework Applied to State and Local Immigration-Related Law Enforcement Policies}

As discussed in Chapter Two, states and localities have adopted policies over the past 15 years to increase the involvement of law enforcement personnel in immigration enforcement, either through participation in $287(\mathrm{~g})$ programs or through legislative policy change (e.g., omnibus legislation). Relative to the status quo, this represents a restrictive policy toward unauthorized immigrants (see Table 3.2). For this policy change, we first consider the expected effects for the relevant outcome domains listed in Table 3.3. We then look to empirical research for evidence of the expected effects. We conclude by presenting the completed framework for law enforcement policies.

\section{Expected Effects}

Following the discussion earlier in this chapter, the first-order expected impact of increasing immigration-related law enforcement at the state (or local) level would be to reduce the number of unauthorized immigrants residing in the state (or locality). Table 3.4 shows this expected main effect, consistent with the stated aims of law enforcement policies, and the associated secondary effects discussed earlier.

A potential unintended spillover effect of increased enforcement, however, may be a reduction in the number of authorized immigrants and other groups, such as Hispanic U.S. citizens (naturalized or native-born). This may arise if the application of law enforcement efforts directly affects authorized immigrants or U.S. citizens - for example, when there is racial profiling. Nontargeted population groups also may leave the state or locality (or elect not to move to the jurisdiction) because their family members are unauthorized and fear detection and deportation. Emigration or reduced immigration of nontargeted populations would have secondary impacts similar to those associated with the reduction in the level of unauthorized immigrants (see Table 3.4). 
Table 3.4. Potential Impacts of Expanded State- and Local-Level Immigration-Related Law Enforcement

\begin{tabular}{|c|c|}
\hline Potential Main Impacts & Potential Secondary Impacts \\
\hline $\begin{array}{l}\text { Decreased number of } \\
\text { unauthorized immigrants }\end{array}$ & $\begin{array}{l}\text { - Increased wages of unskilled authorized workers/decreased wages of } \\
\text { skilled authorized workers } \\
\text { - } \quad \text { Decreased economic output/increase price of some services } \\
\text { - Fiscal impact unclear (both reduced tax revenue and reduced } \\
\text { government expenditures) }\end{array}$ \\
\hline $\begin{array}{l}\text { Decreased number of authorized } \\
\text { immigrants or other population } \\
\text { subgroups (e.g., Hispanic U.S. } \\
\text { citizens) }\end{array}$ & $\begin{array}{l}\text { - Increased wages of unskilled authorized workers/decreased wages of } \\
\text { skilled authorized workers } \\
\text { - } \quad \text { Decreased economic output/increase price of some services } \\
\text { - Fiscal impact unclear (both reduced tax revenue and reduced } \\
\text { government expenditures) }\end{array}$ \\
\hline $\begin{array}{l}\text { Reduced participation in public } \\
\text { programs and services or } \\
\text { reduced civic engagement on the } \\
\text { part of unauthorized or } \\
\text { authorized immigrants in the } \\
\text { jurisdiction }\end{array}$ & $\begin{array}{l}\text { - Unfavorable outcomes associated with reduced public program take-up } \\
\text { (e.g., worse health outcomes, lower education attainment, etc.) } \\
\text { - Unfavorable outcomes associated with reduced civic engagement (e.g., } \\
\text { reduction in reporting of crime) }\end{array}$ \\
\hline $\begin{array}{l}\text { Increased law-enforcement costs } \\
\text { and/or decreased non- } \\
\text { immigration-related law- } \\
\text { enforcement activities }\end{array}$ & $\begin{array}{l}\text { If total government expenditures increase: } \\
\text { - Increased taxes to pay for additional services } \\
\text { If government expenditures remain unchanged: } \\
\text { - Increased unlawful activities in domains where non-immigration-related } \\
\text { - law-enforcement activities decline } \\
\text { Reductions in other local government services with the associated } \\
\text { consequences }\end{array}$ \\
\hline
\end{tabular}

For both unauthorized and authorized immigrants who are located in the restrictive jurisdiction, increased enforcement activity may heighten feelings of social exclusion, resulting in reduced participation in publicly provided programs and services or reduced civic engagement. Thus, another potential unintended spillover consequences is lower take-up of programs for which authorized immigrants or U.S. citizens qualify (e.g., U.S. citizen children of authorized or unauthorized parents). Reduced participation in Medicaid on the part of U.S. citizen children, for example, could produce unfavorable effects on child health. The consequences of reduced participation in publicly funded programs will depend on the specific program or service and the extent to which participation affects adult or child outcomes. Likewise, reduced civic engagement on the part of unauthorized or authorized immigrants may have such consequences as a reduced willingness to report on crimes, which may have unfavorable effects on community safety.

Planning for, implementing, and executing a $287(\mathrm{~g})$ program requires personnel and other real resources. Thus, a potential fourth main effect would be on law enforcement budgets and services. If the budget for state and local law enforcement activities is not fixed, then the increased law enforcement activities related to unauthorized immigration would be expected to increase the overall costs to the public sector. Law enforcement personnel may need to expand to accomplish the new duties related to interior enforcement, and the costs associated with detection and detention would also increase. Those higher costs would require new taxes to keep the 
public-sector budget in balance. If state and local budgets cannot be increased, then the increase in immigration-related law enforcement necessarily would crowd out other non-immigrationrelated law enforcement activities or reduce publicly provided goods and services in other areas (e.g., health, education, transportation). Indeed, accounts of implementing 287(g) programs at the state and local level indicate that resources have been constrained as new programs have been put in place and become operational (Waslin, 2010). If there is a deterrent effect of law enforcement on unlawful activity, then a reduction in law enforcement activity would be expected to increase unlawful activity in areas where personnel and other resources are reduced. If the higher immigration-related enforcement costs are covered by reductions in other government services, there may be associated consequences in those domains. These potential effects are summarized in Table 3.4 .

\section{Empirical Evidence}

We now turn our attention to a set of studies that examine the relationship between state or substate policies regarding immigration enforcement and demographic, economic, or social outcomes. Several early studies provided case studies of specific jurisdictions (see the literature reviewed by O'Neil, 2013). These descriptive case study results suggested that the adoption of 287 (g) programs substantially reduced the number of unauthorized immigrants in the affected community and pointed to evidence of a chilling effect on authorized immigrants and U.S. citizens, as well (Capps et al., 2011).

Our focus is on those studies that use methods, such as difference-in-differences, to obtain causal estimates. ${ }^{5}$ Difference-in-differences estimation exploits the variation across states (and localities) at a point in time and over time to examine changes in the outcome of interest in communities with restrictive immigration enforcement (the treatment group) against the change for communities that do not have the legislation (the comparison group). Table 3.5 summarizes the results from six studies that examine the relationship between various state-level (or locallevel) immigration-related enforcement mechanisms and key outcomes. Five studies assess the impact of entering into an agreement with ICE to operate a $287(\mathrm{~g})$ program; the sixth study examines the impact of having a Secure Communities program in place. The studies vary in the time period considered, the geographic unit of analysis, and the outcomes of interest.

\footnotetext{
${ }^{5}$ In reviewing the literature, we omit studies that focus on national-level policy change with respect to immigration enforcement, such as Orrenius and Zavodny (2009), who assess the impact of federal interior enforcement policy changes following the $9 / 11$ terrorist attacks. In general, national-level studies find the expected effect that tougher enforcement reduces the number of unauthorized immigrants and their employment.
} 
Table 3.5. Studies Assessing Impacts of Expanding State- and Local-Level Immigration-Related Enforcement

\begin{tabular}{|c|c|c|c|c|}
\hline Study & Policy Examined & Method & $\begin{array}{l}\text { Years and } \\
\text { Geography } \\
\text { Covered }\end{array}$ & $\begin{array}{l}\text { Estimated Effect of Expanding } \\
\text { Enforcement }\end{array}$ \\
\hline Parrado (2012) & $\begin{array}{l}\text { State and county } \\
287(\mathrm{~g}) \text { programs }\end{array}$ & $\begin{array}{l}\text { Difference-in- } \\
\text { differences }\end{array}$ & $\begin{array}{l}\text { 2005-2009 } \\
\text { U.S. } \\
\text { metro areas }\end{array}$ & $\begin{array}{l}\text { - Size of Mexican foreign-born } \\
\text { population (-) } \\
\text { Unemployment rate of native whites } \\
\text { and native blacks with a high school } \\
\text { education or less }(0)\end{array}$ \\
\hline $\begin{array}{l}\text { Kostandini, } \\
\text { Mykerezi, and } \\
\text { Escalante (2013) }\end{array}$ & $\begin{array}{l}\text { State and county } \\
287(\mathrm{~g}) \text { programs }\end{array}$ & $\begin{array}{l}\text { Difference-in- } \\
\text { differences }\end{array}$ & $\begin{array}{l}2002-2010 \\
\text { U.S. counties }\end{array}$ & $\begin{array}{l}\text { - } \quad \text { Share of population who are } \\
\text { noncitizens }(-) \\
\text { - } \quad \text { Share of population who are foreign- } \\
\text { born with fewer than } 20 \text { years in the } \\
\text { United States }(-) \\
\text { - } \quad \text { Earnings of farm workers }(+) \\
\text { - } \quad \text { Share of agriculture production } \\
\text { expenses for hired labor }(-) \\
\text { - Share of hired labor in total } \\
\text { production expenses for agriculture } \\
\text { sector }(-) \\
\text { - } \\
\text { Expense per worker in agriculture } \\
\text { sector }(+) \\
\text { Agriculture sector profitability }(-)\end{array}$ \\
\hline O'Neil (2013) & $\begin{array}{l}\text { State and county } \\
287(\mathrm{~g}) \text { programs }\end{array}$ & $\begin{array}{l}\text { Difference-in- } \\
\text { differences }\end{array}$ & $\begin{array}{l}2005-2010 \\
\text { U.S. counties }\end{array}$ & $\begin{array}{l}\text { - Annual growth of foreign-born } \\
\text { population (0) } \\
\text { - Annual growth of Hispanic population } \\
\text { - } 0) \\
\text { - Annual growth of Hispanic noncitizen } \\
\text { population (0) }\end{array}$ \\
\hline Watson (2013) & $\begin{array}{c}\text { State and county } \\
287(\mathrm{~g}) \text { programs, } \\
\text { task force versus } \\
\text { jail enforcement } \\
\text { models }\end{array}$ & $\begin{array}{l}\text { Difference-in- } \\
\text { differences }\end{array}$ & $\begin{array}{l}\text { 2005-2011 } \\
\text { U.S. } \\
\text { state and } \\
\text { substate } \\
\text { areas }\end{array}$ & $\begin{array}{l}\text { 287(g) task force model } \\
\text { - Foreign-born cross-state migration } \\
\text { within the United States (+) (outflows } \\
\text { [+]; inflows [0]) } \\
\text { - Foreign-born exits from the United } \\
\text { States }(0) \\
\text { - } \text { New immigration from abroad }(0) \\
\text { - Relocation of noncitizen college- } \\
\text { educated individuals }(+)\end{array}$ \\
\hline $\begin{array}{l}\text { Miles and Cox } \\
(2014)\end{array}$ & $\begin{array}{c}\text { County Secure } \\
\text { Communities } \\
\text { programs }\end{array}$ & $\begin{array}{l}\text { Difference-in- } \\
\text { differences }\end{array}$ & $\begin{array}{l}2004-2012 \\
\text { U.S. counties }\end{array}$ & $\begin{array}{l}\text { - Overall crime rate }(0) \\
\text { - Specific violent crime rates }(0)\end{array}$ \\
\hline Watson (2014) & $\begin{array}{l}\text { State and county } \\
287(\mathrm{~g}) \text { programs } \\
\text { (measured by } \\
\text { deportation } \\
\text { propensity) }\end{array}$ & $\begin{array}{l}\text { Difference-in- } \\
\text { differences }\end{array}$ & $\begin{array}{c}\text { 2005-2007 } \\
\text { U.S. } \\
\text { states and } \\
\text { state clusters }\end{array}$ & $\begin{array}{l}\text { - Medicaid participation of U.S. citizen } \\
\text { children of noncitizens (-) } \\
\text { - Health status of U.S. citizen children } \\
\text { of noncitzens (-) }\end{array}$ \\
\hline
\end{tabular}

NOTE: + / - / 0 = increase, decrease, and no effect, respectively, for the outcome in states with restrictive stateand local-level immigration-related law enforcement.

For the studies that rely on population-based surveys, such as the American Community Survey, it is generally not possible to specifically examine effects of immigration enforcement policies on unauthorized immigrants because they are not identified in the data. Rather, various proxies for the population of interest are considered, such as the foreign-born or noncitizen 
populations in aggregate or from specific countries of origin (e.g., Mexico). All of the studies also have to contend with confounding factors, such as the Great Recession, which also affected the unauthorized immigrants and the proxy groups during the same period. Studies also differ in the time period covered and the geographic units analyzed.

Four of the studies examine the effect of the enforcement policy on the size of the immigrant population, both the groups that proxy for the targeted population (unauthorized immigrants) and the nontargeted population (naturalized U.S. citizens and the native-born). Of the two remaining studies, one examines the effect of immigration-related enforcement on crime rates, while the other focuses on the take-up of a specific public benefit, Medicaid. None of the studies consider the effects of the policies on the law enforcement sector, the fourth expected domain of impact listed in Table 3.4.

\section{Effects on Population of Unauthorized Immigrants}

The first four studies listed in Table 3.5 produce mixed evidence of the effectiveness of the $287(\mathrm{~g})$ program on the populations that proxy for the unauthorized population. One of the first such studies, Parrado (2012) produced estimates of an absolute decline in the Mexican foreignborn population in metropolitan areas between 2005 and 2009, although the effects were limited to several larger jurisdictions with particularly vigorous $287(\mathrm{~g})$ programs. Even with the measured impacts, the $287(\mathrm{~g})$ program did not produce a very sizable reduction in the proxy population.

In contrast, based on data covering 2005 to 2010, O'Neil (2013) examined growth in three populations: the foreign-born, Hispanics, and Hispanic noncitizens, wherein the last group is viewed as the closest proxy for unauthorized immigrants. Using difference-in-differences estimation with county-level data, he finds no effect of having a 287(g) program on growth for any of the three population groups. This null result also holds when the empirical models are based on a measure of the degree of participation in the $287(\mathrm{~g})$ program (as captured by per capita 287 (g) detentions).

Kostandini, Mykerezi, and Escalante (2013) examine the effect of state and county 287(g) programs for an even longer time period - from 2002 to 2010 - on two groups of likely unauthorized immigrants: noncitizens and the foreign-born who have resided in the United States for fewer than 20 years. For both groups, using difference-in-differences estimation with countylevel data, adopting a $287(\mathrm{~g})$ program is associated with a decline in the share of the group in the county's population.

Watson (2013) considers additional dimensions of migration and the effects of the 287(g) task force model (now discontinued) versus the jail enforcement model. She finds the strongest effects for the task force model on cross-area outflows among the foreign-born (i.e., across states, divisions, and regions). The estimates show no effects of $287(\mathrm{~g})$ programs on migration into or out of the United States. Watson (2013) further finds that the relocation effects in noncitizens tend to be among college graduates, perhaps suggesting that the policy misses its 
target (and perhaps suggesting that the effect is higher on authorized immigrants). The small scale of the $287(\mathrm{~g})$ programs in terms of the share of the population covered by the agreements (less than 4 percent) means that the estimated effect on population movements is very modest.

\section{Effects on Population of Other Immigrants and Natives}

Several of the studies listed in Table 3.5 also examine the effect of 287(g) programs on outcomes for native population groups. For example, Parrado (2012) finds no effects of 287(g) programs on the unemployment rate for native-born whites and African-Americans with a high school education or less.

Watson (2014) considers the effect of 287(g) enforcement programs on the take-up of Medicaid among eligible U.S. citizen children whose parents are noncitizens. She hypothesizes that the chilling effect of an anti-immigrant climate would deter enrollment in the program, for which U.S. citizen children are eligible. Indeed, the study finds indirect support for this spillover hypothesis in mixed-status families with an estimated decline in Medicaid participation in those states adopting a $287(\mathrm{~g})$ program, particularly for subgroups with high rates of unauthorized immigrants (e.g., immigrants from Mexico). The study also finds some suggestive evidence of an associated decline in child health status.

\section{Effects on Specific Sectors}

Kostandini, Mykerezi, and Escalante (2013), discussed above, also examine the effects of adopting state or county $287(\mathrm{~g})$ programs on the agricultural sector. The study finds that adopting a $287(\mathrm{~g})$ program has consequences for the agriculture industry that are consistent with a reduction in labor supply, such as increased earnings of farm workers and, for the agriculture sector, a reduction in hired labor as a share of total production expenses, an increase in expense per worker, and a decrease in farm profitability.

\section{Effects on Crime}

As discussed previously, research generally has not found a relationship between immigration levels and crime. Yet one motivation for policies like the $287(\mathrm{~g})$ program or the subsequent Secure Communities program is to make communities safer. Miles and Cox (2014) use the variation in the roll-out of the Secure Communities program to assess the effects of the program on overall crime rates and rates of specific types of crime. They find no effect of Secure Communities on the overall crime rate or the violent crime rate. The results suggest a possible reduction in property crimes, specifically burglary and motor vehicle theft, but the effects are very small.

\section{Completed Framework}

The empirical evidence provides support for at least some of the hypothesized effects of expanding state and local immigration-related law enforcement delineated in Table 3.4. Based on 
this evidence, Table 3.6 provides a completed version of the cost-benefit framework in Table 3.1, showing the expected main impacts (rows) of expanding state and local immigration-related law enforcement. The columns differentiate the expected effects for four main stakeholder groups in the adopting state: unauthorized immigrants, authorized immigrants and the native-born, employers, and state and local government. We have shaded the row entries in green for those impact areas that have been examined in the empirical literature using rigorous methods. Expected effects that are shaded in yellow have little or no evidence base and are, as such, less certain.

Table 3.6. Accounting for Potential Costs and Benefits of Expanding State- and Local-Level Immigration-Related Enforcement

\begin{tabular}{|c|c|c|c|c|}
\hline \multirow[b]{2}{*}{$\begin{array}{l}\text { Potential Main } \\
\text { Impacts }\end{array}$} & \multicolumn{4}{|c|}{ Stakeholders } \\
\hline & $\begin{array}{l}\text { Unauthorized } \\
\text { Immigrants }\end{array}$ & $\begin{array}{l}\text { Authorized } \\
\text { Immigrants and } \\
\text { Native-Born }\end{array}$ & Employers & $\begin{array}{c}\text { State and Local } \\
\text { Government }\end{array}$ \\
\hline $\begin{array}{l}\text { Decreased number } \\
\text { of unauthorized } \\
\text { immigrants }\end{array}$ & $\begin{array}{c}+ \text { or - } \\
\text { depending on } \\
\text { difference in skill mix } \\
\text { between those who } \\
\text { leave and current } \\
\text { residents and } \\
\text { earnings impacts for } \\
\text { those who leave }\end{array}$ & $\begin{array}{c}\text { or - } \\
\text { depending on skill level } \\
\text { and changes in relative } \\
\text { wages }\end{array}$ & $\begin{array}{c}- \text { or } 0 \\
\text { depending on skill } \\
\text { mix of employees }\end{array}$ & $\begin{array}{l}+ \text { or }- \\
\text { depending on net } \\
\text { fiscal impact of } \\
\text { unauthorized who } \\
\text { leave }\end{array}$ \\
\hline $\begin{array}{l}\text { Decreased number } \\
\text { of authorized } \\
\text { immigrants or other } \\
\text { population } \\
\text { subgroups (e.g., } \\
\text { Hispanic U.S. } \\
\text { citizens) } \\
\end{array}$ & $\begin{array}{l}+ \text { or - } \\
\text { depending on skill } \\
\text { level and changes in } \\
\text { relative wages }\end{array}$ & $\begin{array}{c}+ \text { or - } \\
\text { depending on difference } \\
\text { in skill mix between } \\
\text { those who leave and } \\
\text { current residents and } \\
\text { earnings impacts for } \\
\text { those who leave }\end{array}$ & $\begin{array}{c}- \text { or } 0 \\
\text { depending on skill } \\
\text { mix of employees }\end{array}$ & $\begin{array}{c}+ \text { or }- \\
\text { depending on net } \\
\text { fiscal impact of } \\
\text { population } \\
\text { subgroups who } \\
\text { leave }\end{array}$ \\
\hline $\begin{array}{l}\text { Reduced } \\
\text { participation in } \\
\text { public programs } \\
\text { and services or } \\
\text { reduced civic } \\
\text { engagement on the } \\
\text { part of } \\
\text { unauthorized or } \\
\text { authorized } \\
\text { immigrants in the } \\
\text { jurisdiction }\end{array}$ & $\begin{array}{l}- \\
\text { from reduced use of } \\
\text { public programs and } \\
\text { services or reduced } \\
\text { civic engagement on } \\
\text { the part of those } \\
\text { who remain in the } \\
\text { jurisdiction }\end{array}$ & $\begin{array}{l}- \\
\text { from reduced use of } \\
\text { public programs and } \\
\text { services or reduced } \\
\text { civic engagement on } \\
\text { the part of those who } \\
\text { remain in the jurisdiction }\end{array}$ & Not applicable & $\begin{array}{l}+ \\
\text { from reduced use of } \\
\text { public programs } \\
\text { and services on the } \\
\text { part of those who } \\
\text { remain in the } \\
\text { jurisdiction }\end{array}$ \\
\hline $\begin{array}{l}\text { Increased law } \\
\text { enforcement costs } \\
\text { and/or decreased } \\
\text { non-immigration- } \\
\text { related law } \\
\text { enforcement } \\
\text { activities }\end{array}$ & $\begin{array}{c}\text { o or - } \\
\text { depending on } \\
\text { increased taxes, } \\
\text { decreased law- } \\
\text { enforcement } \\
\text { services, or } \\
\text { decreased public } \\
\text { services in other } \\
\text { areas }\end{array}$ & $\begin{array}{c}0 \text { or - } \\
\text { depending on increased } \\
\text { taxes, decreased law- } \\
\text { enforcement services, } \\
\text { or decreased public } \\
\text { services in other areas }\end{array}$ & $\begin{array}{c}0 \text { or - } \\
\text { depending on } \\
\text { increased taxes, } \\
\text { decreased law- } \\
\text { enforcement } \\
\text { services, or } \\
\text { decreased public } \\
\text { services in other } \\
\text { areas } \\
\end{array}$ & $\begin{array}{c}0 \\
\text { if increased cost of } \\
\text { immigration-related } \\
\text { law enforcement is } \\
\text { paid for with } \\
\text { increased taxes or } \\
\text { reduced spending } \\
\text { in other areas }\end{array}$ \\
\hline
\end{tabular}

NOTES: + / - / 0 = favorable, unfavorable, or neutral outcome, respectively, from perspective of stakeholder.

Green shading indicates evidence for the main impacts; yellow indicates little or no evidence. 
For simplicity, we have omitted stakeholder groups outside of the adopting state. Impacts for nonadopting states, where the effects are likely to be small (if any), generally have not been explored in the literature. Thus, for purposes of cost-benefit accounting in Table 3.6, we are implicitly taking a societal perspective, but from the standpoint of a given state adopting an immigration-related policy. The cost-benefit frameworks we develop can readily be extended to a national perspective in order to capture stakeholder groups beyond the focal state (e.g., unauthorized immigrants in other states, authorized immigrants and the native-born in other states, employers in other states, and the federal government).

Table 3.6 illustrates the range of impacts that should be accounted for in a complete CBA of expanding state- and local-level immigration-related enforcement.

- Decreased number of unauthorized immigrants. The empirical research summarized in Table 3.5 provides some evidence for the hypothesized negative effect of increased enforcement on the number of unauthorized immigrants. Accounting for this impact in a CBA would require estimating the resulting effect on the earnings for unauthorized immigrants, authorized immigrants, and the native-born according to the skill mix of the affected groups before and after the policy change. Employers also might gain or lose from the changes in labor supply and relative wages (e.g., in the agriculture section, consistent with the empirical research noted above). The fiscal impact at the state and local level will depend on the net fiscal impact of the unauthorized immigrants who leave the jurisdiction.

- Decreased number of authorized immigrants or other population subgroups. Few studies have examined the effect of increased law enforcement on authorized immigrants and the native-born. Nevertheless, a comprehensive CBA should aim to capture this potential effect as well, with a similar pattern of stakeholder impacts as the effects for unauthorized immigrants noted above. Such a change has implications for the well-being of the affected groups, as well as the fiscal balance for the public sector.

- Reduced participation in public programs and services or reduced civic engagement on the part of unauthorized or authorized immigrants in the jurisdiction. One study summarized in Table 3.5 found the expected negative effect of enforcement policies on the participation in public services, such as Medicaid, on the part of U.S. citizen children who continue to reside in the state. If this effect extends to the few programs for which the unauthorized population qualify (e.g., public education), it would be important to capture these impacts in an integrated fashion in any CBA. Such effects are likely to be unfavorable for the affected immigrant groups, but they may be favorable for nonaffected groups depending on the nature of the public program or service. ${ }^{6}$ Likewise, although

\footnotetext{
${ }^{6}$ For example, in the case of congestion effects or programs that are not entitlements, those who continue to access the program or services may gain from the reduced participation on the part of affected immigrants.
} 
largely unexplored in the literature, there may be important effects from diminished civic engagement in the immigrant community.

- Increased law enforcement costs and/or decreased non-immigration-related law enforcement activities. We found no empirical research quantifying the expected effects on law enforcement activity in aggregate or the shift in the resources devoted to different types of law enforcement. Nevertheless, it would be important to capture the potential consequences for private parties (unauthorized or authorized immigrants and employers), as well as the public sector (e.g., state and local governments) from such impacts.

\section{Framework Applied to E-Verify and Other Status Verification Systems}

As we discussed in Chapter Two, several states now mandate the use of E-Verify, either for specific subsets of employers (typically those in the public sector or public sector contractors) or for all employers above a given size. As with enforcement policy, mandating the use of E-Verify is a shift toward a restrictive environment relative to the status quo where E-Verify is optional (see Table 3.2). In the remainder of this section, we enumerate the expected effects of requiring the use of E-Verify, document the empirical evidence regarding those expected effects, and complete the cost-benefit framework for E-Verify.

\section{Expected Effects}

To examine the expected effects of mandating E-Verify, we begin by considering the case where E-Verify is required for all employers above a given size. For the most part, the set of expected impacts will be the same when the E-Verify mandate applies to a subset of employers. Where there are differences in expected impact between the two policy variants, we provide additional discussion. In addition, the cost-benefit framework discussed here can be used to analyze other employment-related policies that affect unauthorized immigrants, such as limiting occupational or business licensing to those who are legally present in the United States (NCSL, 2015a). Because such policies could increase the costs (or reduce the benefits) to employers of hiring unauthorized workers - and have the same effect on those unauthorized workers - the expected effects of such policies would likely mirror those for E-Verify (or partial E-Verify). Thus, with some modification, the cost-benefit framework can be extended to cover a wider range of employment-related immigration policies.

Table 3.7 shows the main expected impacts associated with a state mandate to require the use of E-Verify. As a restrictive policy, like the law enforcement policies discussed above (Table 3.4), the first expected impact would be to reduce the number of unauthorized immigrants through increased emigration or reduced immigration. We would also expect spillover effects to authorized immigrants and other population subgroups that, while not targeted by the policy change, also might elect to reside in another state where there is a less hostile environment and where they are less likely to experience statistical discrimination (which arises when employers 
cannot easily distinguish unauthorized and authorized workers and therefore use personal characteristics to profile which job applicants are most likely to be unauthorized). Table 3.7 also lists the associated secondary impacts discussed previously that would be expected as a result of a decline in state population (i.e., those related to wages, economic output, and fiscal balance).

Table 3.7. Potential Impacts of State Mandate to Use E-Verify or Other Status Verification Systems

\begin{tabular}{|c|c|}
\hline Potential Main Impacts & Potential Secondary Impacts \\
\hline $\begin{array}{l}\text { Decreased number of unauthorized } \\
\text { immigrants }\end{array}$ & $\begin{array}{l}\text { - Increased wages of unskilled authorized workers/decreased wages of } \\
\text { skilled authorized workers } \\
\text { - } \quad \text { Decreased economic output/increase price of some services } \\
\text { - Fiscal impact unclear (both reduced tax revenue and reduced } \\
\text { government expenditures) }\end{array}$ \\
\hline $\begin{array}{l}\text { Decreased number of authorized } \\
\text { immigrants or other population } \\
\text { subgroups (e.g., Hispanic U.S. } \\
\text { citizens) }\end{array}$ & $\begin{array}{l}\text { - Increased wages of unskilled authorized workers/decreased wages of } \\
\text { skilled authorized workers } \\
\text { - } \quad \text { Decreased economic output/increase price of some services } \\
\text { - Fiscal impact unclear (both reduced tax revenue and reduced } \\
\text { government expenditures) }\end{array}$ \\
\hline $\begin{array}{l}\text { Decreased employment among } \\
\text { unauthorized immigrants who reside } \\
\text { in the state }\end{array}$ & $\begin{array}{l}\text { - Reduced earnings for unauthorized immigrants } \\
\text { - } \quad \text { Reduced tax revenue at the federal, state, and local level }\end{array}$ \\
\hline $\begin{array}{l}\text { Increased or decreased employment } \\
\text { among authorized immigrants and } \\
\text { natives who reside in the state } \\
\end{array}$ & $\begin{array}{l}\text { - Reduced or increased earnings } \\
\text { - Reduced or increased tax revenue at the federal, state, and local level }\end{array}$ \\
\hline $\begin{array}{l}\text { Cost to implement and enforce the } \\
\text { policy }\end{array}$ & $\begin{array}{l}\text { - Cost to individuals to correct E-Verify database records when in error } \\
\text { - Costs to firms to comply with regulations } \\
\text { - Cost to government to implement and enforce }\end{array}$ \\
\hline $\begin{array}{l}\text { For partial E-Verify implementation, } \\
\text { shift in employment from sectors with } \\
\text { E-Verify requirement to sectors } \\
\text { without E-Verify requirement }\end{array}$ & - Changes in relative wages across sectors \\
\hline
\end{tabular}

For unauthorized immigrants who stay in the state, the required use of E-Verify and associated penalties for hiring unauthorized workers would be expected to raise the cost to employers of hiring unauthorized workers compared with authorized workers, thereby reducing employers' demand for unauthorized workers (Lofstrom, Bohn, and Rafael, 2011). The likely result would be a reduction in employment of unauthorized workers, which has costs for the workers (e.g., lost earnings) and the public sector (reduced tax revenue if employment overall declines). The reduced employment level effectively reduces labor supply, which has the same effects noted above in the context of immigration-related law enforcement.

For authorized immigrants and native workers, the employment effects will depend on the extent to which they are close substitutes for unauthorized workers and the magnitude of the overall decline in employment levels expected with the rise in labor cost (Lofstrom, Bohn, and Rafael, 2011). If employers can distinguish between unauthorized and authorized workers, employment of the latter - when they are close substitutes for unauthorized workers (e.g., Hispanic naturalized U.S. citizens) — should increase as employers shift their hiring in favor of 
those eligible to work. However, if employers have imperfect information, they may engage in statistical discrimination and reduce employment of authorized workers who have traits that are prevalent among the unauthorized (e.g., Hispanic ethnicity, low education). The uncertainty in this effect is shown in Table 3.7.

Imposing E-Verify has direct operational costs to the public sector, employers, and authorized workers (General Services Agency, 2008; Arvelo, 2011; Rosenblum, 2011). The government faces costs to develop, implement, and maintain the E-Verify database and system and then to enforce the use of the system. Employers bear the cost of working with the E-Verify system to validate employment status. Employees also may be affected, as evidenced by reports that there are sometimes errors in the E-Verify database, which then require employees to take the time to ensure that corrections are made.

Some states have imposed E-Verify only for the public sector or government contractors. Imposing E-Verify in only one sector likely would have different effects, depending on the sector. We would expect unauthorized immigrants to search for jobs in the nonaffected sectors, thus, the policy would be expected to have a null or minimal effect on overall wages - rather, the main impact would be in shifting workers away from sectors covered by the regulation to sectors that are not covered. To the extent that most unauthorized immigrants already work in the private sector, even this effect would be limited. The direct costs associated with the partial variant of the E-Verify mandate also would be lower, as the efforts to enforce it would be limited to the public and contracting sectors.

\section{Empirical Evidence}

Policy researchers have focused extensively on the effects of E-Verify mandates over the past five years. Table 3.8 summarizes nine studies that use robust empirical methods to estimate the impacts of E-Verify. Two of the studies (listed together in the first row) consider the specific effects of the Legal Arizona Workers Act of 2007 (LAWA), one of the first state E-Verify mandates. The remaining studies examine all states and effectively measure the average effect of adopting an E-Verify mandate across the states with the policy. The studies vary in the time periods studied, the outcomes considered, and the population subgroups examined. With one exception, the studies focus on population groups that proxy for the unauthorized population because immigration status is not identified in the nationally representative data sources that provide population and employment data.

\section{Effects on Population of Unauthorized Immigrants}

Several studies listed in Table 3.8 consider the effect of E-Verify requirements on the population of unauthorized immigrants, either measured directly or by proxy using groups that have a high share of unauthorized persons. In studying the impact of Arizona's LAWA, Lofstrom, Bohn, and Rafael (2011) and Bohn, Lofstrom, and Rafael (2014) estimate a negative effect of the legislation on the share of noncitizen Hispanics in the state's population relative to a synthetic control state. 
Their estimates indicate a decline of 1.5 percentage points in the population share, which is equivalent to a loss of 92,000 likely unauthorized immigrants by 2009 . There was no significant decline in the population share of Hispanic naturalized U.S. citizens, a group not targeted by the

Table 3.8. Studies Assessing Impacts of Mandating the Use of E-Verify or Other Status Verification Systems

\begin{tabular}{|c|c|c|c|c|}
\hline Study & $\begin{array}{l}\text { Policy } \\
\text { Examined }\end{array}$ & Method & $\begin{array}{l}\text { Years and } \\
\text { Geography } \\
\text { Covered }\end{array}$ & $\begin{array}{l}\text { Estimated Effect of Mandating the Use of } \\
\text { E-Verify }\end{array}$ \\
\hline $\begin{array}{l}\text { Lofstrom, Bohn, } \\
\text { and Rafael (2011); } \\
\text { Bohn, Lofstrom, } \\
\text { and Rafael (2014) }\end{array}$ & $\begin{array}{l}\text { Arizona } \\
\text { LAWA }\end{array}$ & $\begin{array}{l}\text { Difference-in- } \\
\text { differences } \\
\text { with synthetic } \\
\text { control group }\end{array}$ & $\begin{array}{c}\text { 1998-2009 } \\
\text { Arizona and } \\
\text { other states }\end{array}$ & $\begin{array}{l}\text { - Share of population who are noncitizen } \\
\text { Hispanics }(-) \\
\text { - Share of population who are naturalized } \\
\text { U.S. citizen Hispanics }(0) \\
\text { - Rental property vacancy rate }(+) \\
\text { For noncitizen Hispanic men with less than } \\
\text { high school: } \\
\text { - Total employment rate }(-) \\
\text { - Wage and salary employment rate }(-) \\
\text { - Self-employment rate }(+)\end{array}$ \\
\hline $\begin{array}{l}\text { Bohn, Lofstrom, } \\
\text { and Rafael (2015) }\end{array}$ & $\begin{array}{l}\text { Arizona } \\
\text { LAWA }\end{array}$ & $\begin{array}{l}\text { Difference-in- } \\
\text { differences } \\
\text { with synthetic } \\
\text { control group }\end{array}$ & $\begin{array}{c}\text { 1998-2010 } \\
\text { Arizona and } \\
\text { other states }\end{array}$ & $\begin{array}{l}\text { For lower-skilled native-born } \\
\text { non-Hispanic white men: } \\
\text { - Employment rate }(-) \\
\text { - Unemployment rate }(-) \\
\text { - Earnings }(+)\end{array}$ \\
\hline $\begin{array}{l}\text { Raphael and } \\
\text { Ronconi (2009) }\end{array}$ & $\begin{array}{l}\text { State E-Verify } \\
\text { requirement } \\
\text { and other } \\
\text { immigration- } \\
\text { related } \\
\text { employment } \\
\text { policies }\end{array}$ & $\begin{array}{l}\text { Difference-in- } \\
\text { differences }\end{array}$ & $\begin{array}{l}2006-2008 \\
\text { U.S. states }\end{array}$ & $\begin{array}{l}\text { - Employment of Hispanic population with } \\
\text { low education (-) } \\
\text { - Employment of foreign-born Hispanic } \\
\text { noncitizen population with low } \\
\text { education (-) } \\
\text { - Population and employment of non- } \\
\text { Hispanic racial-ethnic groups }(0)\end{array}$ \\
\hline $\begin{array}{l}\text { Amuedo-Dorantes } \\
\text { and Bansak (2012) }\end{array}$ & $\begin{array}{l}\text { State E-Verify } \\
\text { requirement, } \\
\text { all employers } \\
\text { versus } \\
\text { public sector } \\
\text { employers }\end{array}$ & $\begin{array}{l}\text { Difference-in- } \\
\text { differences }\end{array}$ & $\begin{array}{l}\text { 2004-2010 } \\
\text { U.S. states }\end{array}$ & $\begin{array}{l}\text { For Hispanic noncitizens with high school } \\
\text { diploma or less: } \\
\text { - Employment of men (-) and women (-), } \\
\text { all employers only } \\
\text { - Wages of men }(0) \text { and women }(+) \text {, all } \\
\text { employers only } \\
\text { - Employment by industry (+ or - } \\
\text { depending on industry) }\end{array}$ \\
\hline $\begin{array}{l}\text { Amuedo-Dorantes } \\
\text { and Bansak (2014) }\end{array}$ & $\begin{array}{l}\text { State E-Verify } \\
\text { requirement, } \\
\text { all employers } \\
\text { versus } \\
\text { public sector } \\
\text { employers }\end{array}$ & $\begin{array}{l}\text { Difference-in- } \\
\text { differences }\end{array}$ & $\begin{array}{l}\text { 2004-2011 } \\
\text { U.S. states }\end{array}$ & $\begin{array}{l}\text { For Hispanic noncitizens with high school } \\
\text { diploma or less: } \\
\text { - Employment of men }(-) \text { and women }(-) \text {, } \\
\text { all employers only } \\
\text { - Wages of men }(0) \text { and women }(+) \text {, all } \\
\text { employers only } \\
\text { For Hispanic naturalized U.S. citizens with } \\
\text { high school diploma or less: } \\
\text { - Employment of men }(0) \text { and women }(0) \\
\text { - Wages of men }(0) \text { and women }(0) \\
\text { For non-Hispanic natives with high school } \\
\text { diploma or less: } \\
\text { - Employment of men }(+) \text { and women } \\
\text { - Wages of men }(0) \text { and women }(0\end{array}$ \\
\hline
\end{tabular}




\begin{tabular}{|c|c|c|c|c|}
\hline Study & $\begin{array}{l}\text { Policy } \\
\text { Examined }\end{array}$ & Method & $\begin{array}{l}\text { Years and } \\
\text { Geography } \\
\text { Covered }\end{array}$ & $\begin{array}{l}\text { Estimated Effect of Mandating the Use of } \\
\text { E-Verify }\end{array}$ \\
\hline $\begin{array}{l}\text { Orrenius and } \\
\text { Zavodny (2015) }\end{array}$ & $\begin{array}{l}\text { State E-Verify } \\
\text { requirement }\end{array}$ & $\begin{array}{l}\text { Difference-in- } \\
\text { differences }\end{array}$ & $\begin{array}{l}\text { 2002-2012 } \\
\text { U.S. states }\end{array}$ & $\begin{array}{l}\text { For Mexican noncitizens with high school } \\
\text { diploma or less: } \\
\text { - Employment, class of worker, } \\
\text { unemployment, labor force participation, } \\
\text { employer changes (0) } \\
\text { - Hourly earnings (-, men only) } \\
\text { For Mexican naturalized U.S. citizens with } \\
\text { high school diploma or less: } \\
\text { - Employment, unemployed, labor force } \\
\text { participation, earnings, employer } \\
\text { changes }(0) \\
\text { - Wage and salary employment (+, men } \\
\text { For native Hispanics with high school } \\
\text { diploma or less: } \\
\text { - Self-employment, labor force } \\
\text { participation, employer changes (0) } \\
\text { - Employment (+, women only) } \\
\text { - Wage and salary employment (+, } \\
\text { - Unomen only) } \\
\text { For nourly earnings (+, men only) } \\
\text { school diploma or less: } \\
\text { - Employment, class of worker, } \\
\text { unemployment, labor force participation, } \\
\text { earnings, employer changes (0) }\end{array}$ \\
\hline $\begin{array}{l}\text { Amuedo-Dorantes, } \\
\text { Bansak, and } \\
\text { Zebedee }(2015)\end{array}$ & $\begin{array}{l}\text { State E-Verify } \\
\text { requirement }\end{array}$ & $\begin{array}{l}\text { Difference-in- } \\
\text { differences }\end{array}$ & $\begin{array}{l}2004-2011 \\
\text { U.S. states }\end{array}$ & $\begin{array}{l}\text { - Foreign direct investment proxied by } \\
\text { employment of foreign affiliate firms (-) }\end{array}$ \\
\hline $\begin{array}{l}\text { Amuedo-Dorantes, } \\
\text { Puttitanun, and } \\
\text { Martinez-Donate } \\
\text { (2013) }\end{array}$ & $\begin{array}{l}\text { State E-Verify } \\
\text { requirement }\end{array}$ & $\begin{array}{l}\text { Multivariate } \\
\text { regression }\end{array}$ & $\begin{array}{l}\text { 2009-2010 } \\
\text { U.S. states for } \\
\text { sample of } \\
\text { voluntary } \\
\text { returnees }\end{array}$ & $\begin{array}{l}\text { For unauthorized migrants voluntarily } \\
\text { returning to Mexico: } \\
\text { - } \quad \text { Difficulties receiving government } \\
\text { assistance, legal services, or health } \\
\text { care services during last spell }(0) \\
\text { - } \quad \text { Fear of deportation during last spell (+) } \\
\text { - } \quad \text { Moves across state boundaries during } \\
\text { last spell (-) } \\
\text { - Intent to return to the United States in } \\
\text { the near future (0) } \\
\text { For unauthorized migrants deported to } \\
\text { Mexico: } \\
\text { - Difficulties receiving government } \\
\text { assistance, legal services, or health } \\
\text { care services during last spell }(0) \\
\text { - Fear of deportation during last spell }(0) \\
\text { Moves across state boundaries during } \\
\text { last spell (0) } \\
\text { Intent to return to the United States in the } \\
\text { near future (-) }\end{array}$ \\
\hline
\end{tabular}

NOTE: $+/-/ 0$ = indicates increase, decrease, and no effect, respectively, for the outcome in states with restrictive E-Verify or other status verification systems. 
legislation. The study also found an increase in the vacancy rate for rental units, which is consistent with a reduction in the unauthorized population. In contrast, Raphael and Ronconi (2009) do not find a consistent pattern of population effects for subgroups of Hispanic immigrants in an analysis that accounted for state E-Verify legislation and other state employment-related restrictions on unauthorized immigrants. However, their analysis captured state variation for 2006 to 2008 and does not capture the full variation across time incorporated in several other studies.

Amuedo-Dorantes, Puttitanun, and Martinez-Donate (2013) analyze a unique data source to examine the impact of state E-Verify laws on the migration experience of unauthorized Mexican migrants. The sample is drawn from migrants crossing the U.S.-Mexico border in the San DiegoTijuana area and includes both deportees and those returning voluntarily to Mexico. The survey included questions regarding difficulty with accessing services during their most recent stay in the United States, fear of deportation, interstate mobility, and plans to return to the United States in the near future. For both voluntary and involuntary returnees, being in a state with an E-Verify mandate had no apparent effect on difficulty accessing services (e.g., government assistance, legal services, or health care). The authors find evidence that E-Verify mandates may instill a fear of deportation, reduce interstate mobility, and lessen expectations to return to the United States, at least for some unauthorized immigrants. Although the sample of unauthorized immigrants is not representative, the findings suggest that state E-Verify mandates may have little effect on the migration experience and may not substantially deter unauthorized migrants from locating in the affected states.

\section{Effects on Labor Market Outcomes of Unauthorized Immigrants}

Given the focus of E-Verify on employment of unauthorized workers, most of the studies listed in Table 3.8 consider the effects of E-Verify legislation on the labor market outcomes of various subgroups of immigrants. Once again, the evidence is mixed. Several studies find the expected negative effect of the restrictive legislation on employment-related outcomes for groups that proxy for the unauthorized population. For example, Lofstrom, Bohn, and Rafael (2011) and Bohn, Lofstrom, and Rafael (2014) estimate that Arizona's LAWA reduced the employment rate for noncitizen Hispanic men with less than a higher school diploma by 11 to 12 percentage points, the equivalent of 56,000 workers. Further, for the same demographic group, the study estimated that the wage and salary employment rate declined but that the self-employment rate rose, suggesting a shift to a class of employment where the E-Verify requirement can be avoided.

Raphael and Ronconi (2009) also consider employment effects and find some evidence that E-Verify legislation and other immigration-related employment policies reduced employment for various subgroups of the Latino population (e.g., noncitizens with low education). However, the results for any given subgroup are not very robust across alternative specifications, perhaps because of the limited time period studied (2006 to 2008). In contrast, Orrenius and Zavodny (2015) find no effect of E-Verify requirements on several labor market outcomes using a longer time period for analysis.

As discussed in Chapter Two, some states have a partial E-Verify policy, while others have a policy that applies to all employers. Amuedo-Dorantes and Bansak $(2012,2014)$ consider the differential effect of these two approaches on employment-related outcomes for Hispanic noncitizens 
with a high school diploma or less. They find that the main effects are limited to states where EVerify applies to all employers, with a negative effect on employment and a positive effect on wages (for women only) when E-Verify is in place for all employers but no effect when only public-sector employment is covered. Amuedo-Dorantes and Bansak (2012) also document differential positive and negative effects on employment across industries, with gains in employment in those industries (e.g., agriculture and food service) where some employers (e.g., short-term contractors in agriculture, small businesses) are exempted from E-Verify requirements.

\section{Effects on Population and Labor Market Outcomes of Other Immigrants and Natives}

As noted, E-Verify mandates may have effects on the number and share of authorized immigrants and natives, as well as their employment. ${ }^{7}$ This issue has received less attention in the literature, with four of the nine studies in Table 3.8 analyzing population and employment outcomes associated with E-Verify, for naturalized U.S. citizens and native populations. For the most part, these studies show that E-Verify policies can affect nontargeted populations, although the results are not fully consistent across studies.

For example, Bohn, Lofstrom, and Raphael (2015) extend their studies of Arizona's LAWA legislation to consider the effect on authorized lower-skilled workers who potentially compete with unauthorized immigrants. Rather than finding improved outcomes, their analyses suggest modest declines in employment and increased unemployment. The largest effects were among lower-skilled, native-born, non-Hispanic white men, who experienced a decline of 4 percentage points in their employment rate, and an increase of 2 percentage points in their unemployment rate. At the same time, those who are employed receive higher wages. Orrenius and Zavodny (2015) found a similar result. This combination of findings suggests a decline in both labor supply and demand as a result of the E-Verify legislation.

The analyses by Amuedo-Dorantes and Bansak (2014) show no effect of E-Verify policy on the employment or wages of the group of naturalized Hispanics with low education. However, for the native-born non-Hispanic population with low education, being in a state with a universal E-Verify requirement increases the likelihood of employment for both men and women. In contrast, Rafael and Ronconi (2009) find no effect of E-Verify legislation and other employment-related policies on the population or employment of non-Hispanic groups (i.e., whites, African-Americans). Again, the time period studied has less variation than some of the other studies that have addressed the same issue.

Finally, Amuedo-Dorantes, Bansak, and Zebedee (2015) consider the effect of E-Verify laws on foreign direct investment as proxied by employment of foreign affiliate firms. They estimate a negative impact, suggesting that E-Verify requirements may diminish the ability of states to attract foreign direct investment.

\footnotetext{
7 Amuedo-Dorantes, Jin, and Pozo (2015) assess another potential consequence for authorized immigrants: discrimination. Using data from the National Latino Survey, which measures perceptions of discrimination, they find no perceived discrimination effect of E-Verify mandates for Hispanic citizens.
} 


\section{Completed Framework}

Although not conclusive, the existing literature offers evidence in support of the expected effects of mandating the use of E-Verify or other status verification systems. Building on Table 3.7, Table 3.9 provides the completed cost-benefit framework for this restrictive policy. As with Table 3.6, which delineates the framework for state- and local-level immigration-related enforcement, the rows in Table 3.9 show the main expected impacts from mandating E-Verify, and the columns pertain to the four main stakeholder groups in the adopting state. As before, the cost-benefit framework takes a societal perspective in capturing all relevant stakeholder groups within the adopting state. Green shading indicates a stronger evidence base, in contrast to yellow, which indicates a weaker evidence base.

Based on the information in Table 3.9, a complete CBA of mandating the use of E-Verify (or other similar status verification systems) would need to account for the following impacts:

- Decreased number of unauthorized immigrants. The literature summarized in Table 3.8 provides at least some evidence that E-Verify mandates lead to a reduction in the population of unauthorized immigrants in the state. The effects may be short-lived and they may be stronger in states such as Arizona, which required E-Verify for all employers. A CBA would need to account for this demographic effect on wages for unauthorized immigrants, authorized immigrants, and the native-born, based on the changes in the skill mix of the workforce. A full accounting would also capture the effects on employers and the government sector.

- Decreased number of authorized immigrants or other population subgroups. We did not identify any studies to date that examined the effect of E-Verify mandates on the population of authorized immigrants, naturalized U.S. citizens, or the native-born, although several studies did consider how E-Verify mandates affect the labor market outcomes of these nontargeted groups (discussed later). ${ }^{8}$ In general, population declines among these groups would have a similar set of effects across stakeholders as any decrease in the number of unauthorized immigrants (discussed above).

- Decreased employment among unauthorized immigrants who reside in the state. The studies listed in Table 3.8 provide a mixed picture of the potential labor market effects of E-Verify for unauthorized workers. The strongest declines in employment are in states that mandated E-Verify for all employers, while the effects seem to be smaller or nonexistent in states where E-Verify is limited to public-sector employers or contractors. Indeed, there is evidence that unauthorized workers shift to self-employment or uncovered industries to avoid the E-Verify requirement. A complete CBA would account for such employment effects in terms of lost earnings for the affected workers, as well as any net fiscal impact from the lost wage or income taxes.

\footnotetext{
${ }^{8}$ In the next section, we discuss several studies that consider the effects of restrictive omnibus legislation or multiple restrictive policies on population movements of nontargeted groups (i.e., authorized immigrants and nativeborn).
} 
Table 3.9. Accounting for Potential Costs and Benefits of Mandating the Use of E-Verify or Other Status Verification Systems

\begin{tabular}{|c|c|c|c|c|}
\hline \multirow[b]{2}{*}{$\begin{array}{l}\text { Potential Main } \\
\text { Impacts }\end{array}$} & \multicolumn{4}{|c|}{ Stakeholders } \\
\hline & $\begin{array}{l}\text { Unauthorized } \\
\text { Immigrants }\end{array}$ & $\begin{array}{c}\text { Authorized } \\
\text { Immigrants and } \\
\text { Native-Born }\end{array}$ & Employers & $\begin{array}{c}\text { State and Local } \\
\text { Government }\end{array}$ \\
\hline $\begin{array}{l}\text { Decreased number } \\
\text { of unauthorized } \\
\text { immigrants }\end{array}$ & $\begin{array}{c}+ \text { or - } \\
\text { depending on } \\
\text { difference in skill mix } \\
\text { between those who } \\
\text { leave and current } \\
\text { residents and } \\
\text { earnings impacts for } \\
\text { those who leave }\end{array}$ & $\begin{array}{l}+ \text { or - } \\
\text { depending on skill } \\
\text { level and changes in } \\
\text { relative wages }\end{array}$ & $\begin{array}{c}- \text { or } 0 \\
\text { depending on skill } \\
\text { mix of employees }\end{array}$ & $\begin{array}{c}+ \text { or }- \\
\text { depending on net } \\
\text { fiscal impact of } \\
\text { unauthorized who } \\
\text { leave }\end{array}$ \\
\hline $\begin{array}{l}\text { Decreased number } \\
\text { of authorized } \\
\text { immigrants or other } \\
\text { population } \\
\text { subgroups (e.g., } \\
\text { Hispanic U.S. } \\
\text { citizens) }\end{array}$ & $\begin{array}{l}+ \text { or - } \\
\text { depending on skill } \\
\text { level and changes in } \\
\text { relative wages }\end{array}$ & $\begin{array}{c}+ \text { or - } \\
\text { depending on } \\
\text { difference in skill mix } \\
\text { between those who } \\
\text { leave and current } \\
\text { residents and } \\
\text { earnings impacts for } \\
\text { those who leave }\end{array}$ & $\begin{array}{c}- \text { or } 0 \\
\text { depending on skill } \\
\text { mix of employees }\end{array}$ & $\begin{array}{c}+ \text { or }- \\
\text { depending on net } \\
\text { fiscal impact of } \\
\text { population } \\
\text { subgroups who } \\
\text { leave }\end{array}$ \\
\hline $\begin{array}{l}\text { Decreased } \\
\text { employment among } \\
\text { unauthorized } \\
\text { immigrants who } \\
\text { reside in the state }\end{array}$ & from lost earnings & Not applicable & Not applicable & $\begin{array}{c}+ \text { or }- \\
\text { depending on net } \\
\text { fiscal impact of } \\
\text { decrease in } \\
\text { employment }\end{array}$ \\
\hline $\begin{array}{l}\text { Increased or } \\
\text { decreased } \\
\text { employment among } \\
\text { authorized } \\
\text { immigrants and } \\
\text { natives who reside in } \\
\text { the state }\end{array}$ & Not applicable & $\begin{array}{c}+ \text { or }- \\
\text { from } \\
\text { increased/decreased } \\
\text { earnings }\end{array}$ & Not applicable & $\begin{array}{c}+ \text { or - } \\
\text { depending on net } \\
\text { fiscal impact of } \\
\text { change in } \\
\text { employment }\end{array}$ \\
\hline $\begin{array}{l}\text { Cost to implement } \\
\text { and enforce the } \\
\text { policy }\end{array}$ & Not applicable & $\begin{array}{l}- \\
\text { from errors in E- } \\
\text { Verify database } \\
\text { records }\end{array}$ & $\begin{array}{l}- \\
\text { from cost to comply } \\
\text { with regulation }\end{array}$ & $\begin{array}{c}- \\
\text { from cost to } \\
\text { implement }\end{array}$ \\
\hline $\begin{array}{l}\text { For partial E-Verify } \\
\text { implementation, shift } \\
\text { in employment from } \\
\text { sectors with E-Verify } \\
\text { requirement to } \\
\text { sectors without E- } \\
\text { Verify requirement }\end{array}$ & $\begin{array}{l}+ \text { or - } \\
\text { depending on skill } \\
\text { level and changes in } \\
\text { relative wages }\end{array}$ & $\begin{array}{l}+ \text { or - } \\
\text { depending on skill } \\
\text { level and changes in } \\
\text { relative wages }\end{array}$ & $\begin{array}{c}- \text { or } 0 \\
\text { depending on skill } \\
\text { mix of employees }\end{array}$ & $\begin{array}{c}+ \text { or }- \\
\text { depending on net } \\
\text { fiscal impact of } \\
\text { shift in } \\
\text { employment } \\
\text { across sectors }\end{array}$ \\
\hline
\end{tabular}

NOTES: + / - / 0 = favorable, unfavorable, or neutral outcome, respectively, from perspective of stakeholder. Green shading indicates evidence for the main impacts; yellow indicates little or no evidence.

\section{- Increased or decreased employment among authorized immigrants and natives who} reside in the state. As noted earlier, mandating E-Verify may increase or decrease employment among authorized immigrants and natives depending on (1) their substitutability with unauthorized immigrants and (2) the overall effect on employment levels with the added hiring cost employers face to comply with an E-Verify mandate. 
Although the empirical research to date is not conclusive, there is suggestive evidence that E-Verify mandates have unfavorable effects on labor market outcomes of close substitutes for unauthorized immigrants, suggesting decreases in both labor supply and demand. As shown in Table 3.9, these labor market impacts would generate costs and benefits for the affected groups and would have fiscal implications for state and local governments that should be accounted for in a comprehensive CBA.

- Cost to implement and enforce the policy. We did not identify any studies that explicitly examined the costs to authorized immigrants, U.S. citizens, and employers of complying with E-Verify, although anecdotal information was cited earlier in this section. These implementation costs for various stakeholders should be included in a CBA.

- For partial E-Verify implementation, shift in employment from sectors with the E-Verify requirement to sectors without the E-Verify requirement. As noted, there is some evidence to indicate that a nonuniversal E-Verify policy could result in cross-industry shifts in employment. Such employment shifts could have implications for wage changes within and among industries, for employer profitability, and for public-sector tax revenues. Such cost or benefits also should be captured in a comprehensive CBA.

\section{Framework Applied to Omnibus Legislation or Multiple Restrictive Policies}

Although we have been discussing single policy changes with respect to unauthorized immigrants, we have demonstrated that states have often adopted policies in bundles, either through omnibus legislation or through separate actions. In terms of our cost-benefit framework, we would generally expect to consider the additive effects across each policy, which might reinforce one another or might be countervailing. In this section, we feature several empirical studies of state omnibus legislation or policy bundles, all of which focus on restrictive policies. We focus on the empirical evidence, as the expected effects and completed framework would combine those presented already (e.g., Tables 3.6 and 3.8). This evidence further strengthens our understanding of the individual policies when they are unbundled.

\section{Empirical Evidence}

Table 3.10 lists three studies examining the impacts of the 2010 Arizona SB 1070 omnibus legislation, one study that examines multiple states with omnibus legislation, and four other studies that created indices to capture the multiple restrictive policies in effect in any given state at a point in time. The first three studies listed rely on several methods to obtain causal estimates and, in some cases, unique data sources to measure the unauthorized population directly. 
Table 3.10. Studies Assessing Impacts of Omnibus Legislation or Combinations of Restrictive Policies

\begin{tabular}{|c|c|c|c|c|}
\hline Study & Policy Examined & Method & $\begin{array}{l}\text { Years and } \\
\text { Geography } \\
\text { Covered }\end{array}$ & $\begin{array}{l}\text { Estimated Effect of Mandating the } \\
\text { Use of E-Verify }\end{array}$ \\
\hline $\begin{array}{l}\text { Hoekstra and } \\
\text { Orozco-Aleman } \\
(2014)\end{array}$ & $\begin{array}{l}\text { Arizona } \\
\text { SB } 1070\end{array}$ & $\begin{array}{c}\text { Pre-post } \\
\text { comparison }\end{array}$ & $\begin{array}{l}\text { 2009-2010 } \\
\text { Arizona }\end{array}$ & $\begin{array}{l}\text { - Flow of unauthorized immigrants to } \\
\text { Arizona from Mexico }(-) \\
\text { - Flow of unauthorized immigrants } \\
\text { from Arizona to Mexico }(0)\end{array}$ \\
\hline Sánchez (2015) & $\begin{array}{l}\text { Arizona } \\
\text { SB } 1070\end{array}$ & $\begin{array}{l}\text { Difference-in- } \\
\text { differences } \\
\text { with synthetic } \\
\text { control group }\end{array}$ & $\begin{array}{l}2009-2012 \\
\text { Arizona and } \\
\text { other states }\end{array}$ & $\begin{array}{l}\text { Share of population who are } \\
\text { noncitizen Hispanic (-) }\end{array}$ \\
\hline $\begin{array}{l}\text { Amuedo- } \\
\text { Dorantes and } \\
\text { Lozano }(2015 b)\end{array}$ & $\begin{array}{l}\text { Arizona } \\
\text { SB } 1070\end{array}$ & $\begin{array}{l}\text { Difference-in- } \\
\text { differences } \\
\text { with synthetic } \\
\text { control group }\end{array}$ & $\begin{array}{l}\text { 1998-2013 } \\
\text { Arizona and } \\
\text { other states }\end{array}$ & $\begin{array}{l}\text { - Share of population who are } \\
\text { noncitizen Hispanic (0) }\end{array}$ \\
\hline $\begin{array}{l}\text { Pham and Van } \\
(2010)\end{array}$ & $\begin{array}{c}\text { City and county } \\
\text { restrictive policies } \\
\text { (e.g., law } \\
\text { enforcement, } \\
\text { government benefits, } \\
\text { housing, } \\
\text { employment, } \\
\text { language) } \\
\end{array}$ & $\begin{array}{l}\text { Difference-in- } \\
\text { differences }\end{array}$ & $\begin{array}{l}2005-2007 \\
\text { U.S. cities and } \\
\text { counties }\end{array}$ & $\begin{array}{l}\text { Total employment (authorized and } \\
\text { unauthorized) (-) } \\
\text { - Industry-specific total employment } \\
\text { (+ or - depending on industry) }\end{array}$ \\
\hline Good (2013) & $\begin{array}{l}\text { State restrictive } \\
\text { omnibus legislation }\end{array}$ & $\begin{array}{l}\text { Difference-in- } \\
\text { differences }\end{array}$ & $\begin{array}{l}\text { 2005-2011 } \\
\text { All U.S. states }\end{array}$ & $\begin{array}{l}\text { Population and share of population } \\
\text { who are likely unauthorized }(-) \\
\text { - Population and share of population } \\
\text { who are native-born or naturalized } \\
\text { U.S. citizens and likely substitutes } \\
\text { for unauthorized }(0)\end{array}$ \\
\hline $\begin{array}{l}\text { Leerkes, } \\
\text { Bachmeier, and } \\
\text { Leach (2013) }\end{array}$ & $\begin{array}{l}\text { State restrictive } \\
\text { policies (e.g., law } \\
\text { enforcement, } \\
\text { government benefits, } \\
\text { education, housing, } \\
\text { employment) }\end{array}$ & $\begin{array}{l}\text { Multivariate } \\
\text { regressions }\end{array}$ & $\begin{array}{l}2000-2010 \\
42 \text { U.S. states }\end{array}$ & $\begin{array}{l}\text { - Share of unauthorized immigrants } \\
\text { residing in state }(-)\end{array}$ \\
\hline $\begin{array}{l}\text { Amuedo- } \\
\text { Dorantes and } \\
\text { Lopez (2015) }\end{array}$ & $\begin{array}{l}\text { State and local } \\
\text { restrictive policies } \\
\text { (e.g., omnibus } \\
\text { legislation; E-Verify; } \\
\text { 287(g) and Secure } \\
\text { Communities } \\
\text { programs) }\end{array}$ & $\begin{array}{l}\text { Difference-in- } \\
\text { differences }\end{array}$ & $\begin{array}{l}\text { 1995-2010 } \\
\text { U.S. MSAs }\end{array}$ & $\begin{array}{l}\text { For Hispanic children of likely } \\
\text { unauthorized immigrants: } \\
\text { - Likelihood of grade repetition }(+) \\
\text { - Likelihood of dropping out of school } \\
\quad(+)\end{array}$ \\
\hline $\begin{array}{l}\text { Amuedo- } \\
\text { Dorantes, } \\
\text { Arenas-Arroyo, } \\
\text { and Sevilla-Sanz } \\
(2015)\end{array}$ & $\begin{array}{l}\text { State and local } \\
\text { restrictive policies } \\
\text { (e.g., omnibus } \\
\text { legislation; E-Verify; } \\
287(g) \text { and Secure } \\
\text { Communities } \\
\text { programs) }\end{array}$ & $\begin{array}{l}\text { Difference-in- } \\
\text { differences }\end{array}$ & $\begin{array}{l}\text { 2005-2011 } \\
\text { U.S. MSAs }\end{array}$ & $\begin{array}{l}\text { Households of U.S. citizen children } \\
\text { with at least one likely unauthorized } \\
\text { parent: } \\
\text { - Likelihood of being in poverty }(+)\end{array}$ \\
\hline
\end{tabular}

NOTE: MSA $=$ Metropolitan Statistical Areas.

$+/-/ 0$ = increase, decrease, and no effect, respectively, for the outcome in states with omnibus legislation or combinations of restrictive policies. 


\section{Effects on Population of Unauthorized Immigrants, Other Immigrants, and Natives}

The three studies examining the impacts of Arizona's 2010 omnibus legislation produce somewhat mixed evidence of the effect of the legislation on the location of unauthorized immigrants or proxies for the targeted group (e.g., noncitizen Hispanic population). Hoekstra and Orozco-Aleman (2014) employ event history and difference-in-differences methods to analyze a special monthly survey of unauthorized workers passing through Mexican border towns on their way to the United States. In the four months between passage of SB 1070 (April 2010) and the federal court injunction (July 2010), they estimate a drop of 30 to 70 percent in unauthorized immigrants coming from Mexico to Arizona, a key migration flow targeted by the legislation. After the court action, the effect dropped by half. At the same time, they found no change in the outflow of unauthorized immigrants from Arizona back to Mexico. Sánchez (2015) employs data from the Current Population Survey (CPS) in which the unauthorized population cannot be identified, so the proxy group is noncitizen Hispanics. He estimates a reduction of 10 to 16 percent in the number of noncitizen Hispanics in Arizona in the 12 months following SB 1070 relative to the trend in a synthetic control state (i.e., a weighted group of other states selected to match the prelegislation demographic patterns in Arizona). The effect is short-lived, however, as the difference is no longer significant after one year. Finally, AmuedoDorantes and Lozano (2015b) also use the CPS and the synthetic control group approach but conclude that the passage of SB 1070 had little effect on the size of the noncitizen Hispanic population through 2013, beyond the impact incurred with the passage of the 2007 LAWA requiring the use of E-Verify (discussed above). ${ }^{9}$ This finding of no effect after three years can be reconciled with Sánchez's (2015) estimate of only a one-year impact of the legislation.

Two other studies examine the effect of omnibus legislation and other restrictive policies across multiple states, either for proxy groups for unauthorized immigrants or direct measures of the targeted population. Good (2013) estimates difference-in-differences models for the population level and population share of 52 demographic groups defined by legal status, raceethnicity, and education level. The study finds that those groups with high proportions of likely unauthorized immigrants (e.g., foreign-born noncitizen Hispanics, foreign-born noncitizen Hispanics with low education and who arrived in the United States after 1982) consistently experienced significant population declines as a result of a state adopting restrictive omnibus legislation. At the same time, those demographic groups that are either authorized immigrants or natives but potential close substitutes for the unauthorized (e.g., native-born Hispanics with low education, native-born whites with low education) do not experience population increases. Thus, as the unauthorized depart states adopting restrictive policies, other populations (e.g., authorized immigrants or natives) do not necessarily migrate to the state to take their place.

Leerkes, Bachmeier, and Leach (2013) take a different approach in developing a composite measure of internal enforcement-specifically, an index composed of the arrest rates for the

\footnotetext{
${ }^{9}$ In a related paper using the synthetic control group approach, Amuedo-Dorantes and Lozano (2015a) estimate the flows of Mexican noncitizens from Arizona to other states as a result of LAWA and SB 1070.
} 
unauthorized population, as well as the share of counties or cities participating in the $287(\mathrm{~g})$ program, and indicators for other state laws relating to E-Verify, driver's licenses, and public benefits. They test the effect of the composite measure on the annual change in the share of unauthorized immigrants (based on aggregate data) over the period from 2000 to 2010 in the 42 states where 99 percent of unauthorized immigrants reside. Given that the study uses a composite measure, the authors cannot disentangle the specific impact of any given policy on the size of the unauthorized population. But their results do suggest that, taken together, restrictive local-level anti-immigration policies are associated with a reduction in the number of unauthorized immigrants in the state. Indeed, the study estimates that, in the absence of the expanded internal control policies, the number of unauthorized immigrants in the United States as a whole could have been 10 to 12 percent higher.

\section{Effects on Employment}

We identified one study that considers the effect of multiple restrictive policies on the labor market. Pham and Van (2010) examine the effects on employment of restrictive policies at the county or city level using data from 2005 to 2007 . The policies considered include those relating to law enforcement, government benefits, housing, employment, and language (e.g., English-only laws). Difference-in-differences estimates show a small decline (1 to 2 percent) in overall employment associated with having one or more restrictive laws. But the data do not allow the authors to examine effects on unauthorized immigrants versus other groups, or on subgroups that are likely to be unauthorized. They also find that some industries gain employment (e.g., restaurants), while employment in other industries declines (e.g., food and beverage stores), suggesting that affected workers may be switching sectors rather than leaving the state altogether.

\section{Effects on Child Schooling and Poverty}

Two studies - Amuedo-Dorantes and Lopez (2015) and Amuedo-Dorantes, Arenas-Arroyo, and Sevilla-Sanz (2015) — examine outcomes for children. Amuedo-Dorantes and Lopez (2015) focus on grade repetition and school dropout rates for Hispanic children of likely unauthorized immigrants. The authors construct an index of the intensity of enforcement measures that captures the combined effect of omnibus immigration laws, E-Verify mandates, $287(\mathrm{~g})$ agreements, and Secure Communities. Based on data from the October supplement to the Current Population Survey and policy variation measured at the MSA level, Amuedo-Dorantes and Lopez (2015) find that stronger interior enforcement increases grade repetition and dropping out, but the effects are concentrated among children ages 6 to 13. Amuedo-Dorantes, ArenasArroyo, and Sevilla-Sanz (2015) examine poverty for U.S. citizen children in households with at least one likely unauthorized parent and create a similar index, differentiating between employment-based enforcement (i.e., E-Verify) versus police-based enforcement (i.e., the other

policies included in the index). The study shows a significant increase in child poverty associated with increased enforcement, where the effect is largest for police-based enforcement. 


\section{Framework Applied to Eligibility for In-State Tuition and Other Financial Aid}

As discussed in Chapter Two, some states have adopted policies, by legislation or other mechanisms, to allow unauthorized immigrants access to in-state tuition at public colleges and universities, provided they are otherwise eligible. Some of these states have gone further and also allowed unauthorized immigrants to access state financial aid. This represents a policy change relative to the status quo where states do not grant in-state residency status to unauthorized immigrants for purposes of applying for in-state tuition. In the discussion that follows, we consider the expected impacts that would be associated with granting access to in-state tuition for eligible students regardless of immigration status. We then summarize the empirical evidence to see whether it accords with our expectations and present the completed framework.

\section{Expected Effects}

By lowering the cost of higher education, states granting access to in-state tuition for qualifying unauthorized immigrants could persuade unauthorized immigrant parents with college aspirations for their children to remain in their state and might induce families in other states that do not provide access to in-state tuition regardless of immigration status to move and establish residency in states that do. Some of these families would include potential labor force participants (e.g., the parents). Thus, as a main effect, we would expect an increase in the supply of immigrants with the corresponding secondary effects on wages, economic output, and state and local budgets discussed earlier and summarized here in Table 3.11.

The other expected main impact would be an increase in the educational attainment of the unauthorized immigrants who remain in or migrate to the state, because they now face a lower cost for postsecondary education. Higher educational attainment could be manifested in a greater number of postsecondary degrees, and there might even be an increase in high school graduates because of the increased opportunity for higher education.

As Table 3.11 indicates, there are a number of potential secondary effects associated with increased educational attainment. First, unauthorized immigrants who experience higher educational attainment will also realize higher earnings, both in the short term and potentially in the longer term. Second, if the demand for higher education subsidies in the form of in-state tuition and other financial aid exceeds the supply, then we would expect a decrease in subsidized enrollments on the part of other groups, such as authorized immigrants and natives who would be displaced by at least some of the unauthorized immigrants now eligible for subsidized tuition. The effect on state budgets depends on whether the total number of subsidized students stays constant (if the number of subsidized slots are fixed with 100-percent take-up) or increase (if subsidized spaces were previously underutilized or can increase with the rise in demand). 
Table 3.11. Potential Impacts of Providing Access to In-State Tuition or Other Financial Aid Regardless of Immigration Status

\begin{tabular}{|c|c|}
\hline Potential Main Impacts & Potential Secondary Impacts \\
\hline $\begin{array}{l}\text { Increased number of } \\
\text { unauthorized immigrants }\end{array}$ & $\begin{array}{l}\text { - Decreased wages of unskilled authorized workers/increased wages of } \\
\text { skilled authorized workers } \\
\text { - } \quad \text { Increased economic output/increase price of some services } \\
\text { - Fiscal impact unclear (both increased state tax revenue and increased } \\
\text { state government expenditures) }\end{array}$ \\
\hline $\begin{array}{l}\text { Increased educational attainment } \\
\text { of unauthorized immigrants }\end{array}$ & $\begin{array}{l}\text { Effects through changes in individual human capital } \\
\text { - Increased earnings for unauthorized immigrants } \\
\text { If demand for subsidies exceeds supply: } \\
\text { - Decreased subsidized enrollments by other groups (authorized } \\
\text { immigrants, nonimmigrants) } \\
\text { If there is a net increase in subsidized enrollments: } \\
\text { - Increased government expenditures for higher education subsidies } \\
\text { If there is a net increase in college-educated versus noncollege-educated } \\
\text { population and labor supply: } \\
\text { - Increased wages of unskilled workers } \\
\text { - Increased economic output } \\
\text { - Increased state tax revenue and reduced state government expenditures }\end{array}$ \\
\hline
\end{tabular}

Third, there may be broader second-order, economywide effects on wages and economic output depending on the impact on the total supply of college-educated and non-collegeeducated workers. If there is a net increase in the college-educated workforce and a corresponding decrease in the less educated workforce, there will be downward pressure on the wages of higher-skilled workers. Economic output and corresponding government revenue might increase as well, if there is a net increase in economywide human capital. To the extent that lower-skilled workers are more dependent on public benefits, this would also cause also a decrease in government expenditures for social programs and thus produce an overall improvement in the fiscal position of the state. These effects are all summarized in Table 3.11.

\section{Empirical Evidence}

The effects of granting access to in-state tuition regardless of immigration status has been an active area of research in recent years. To our knowledge, no studies have examined the impact of in-state tuition policy on the number of unauthorized immigrants or the number of immigrants more generally. Instead, as summarized in Table 3.12, studies have focused on the impact of tuition policies on educational outcomes of immigrants and the native-born population, as well as several other outcomes. All studies listed in the table exploit the natural variation introduced by the fact that states have adopted in-state tuition policies at different points in time. As in the previous sections of this chapter, we review those studies that contrast changes in adopting states with changes in nonadopting states (i.e., employ a difference-in-differences methodology). ${ }^{10}$

\footnotetext{
${ }^{10}$ We omit two studies that provide only a pre-post comparison for states adoption tuition access. Dickson and Pender (2013) examine pre-post enrollments at five Texas universities after the passage of HB 1403, and Keaton et al. (2008) report only pre-post comparison in the six states that enacted unrestrictive policies between 2003 and 2007.
} 
Table 3.12. Studies Assessing Impacts of Providing Access to In-State Tuition or Other Financial Aid Regardless of Immigration Status

\begin{tabular}{|c|c|c|c|c|}
\hline Study & Policy Examined & Method & $\begin{array}{l}\text { Years and } \\
\text { Geography } \\
\text { Covered }\end{array}$ & $\begin{array}{c}\text { Estimated Effect of Making In-State } \\
\text { Tuition Available Regardless of } \\
\text { Immigration Status }\end{array}$ \\
\hline Kaushal (2008) & $\begin{array}{l}\text { States with } \\
\text { in-state tuition } \\
\text { regardless of } \\
\text { immigration } \\
\text { status }\end{array}$ & $\begin{array}{l}\text { Difference-in- } \\
\text { differences }\end{array}$ & $\begin{array}{l}1997-2005 \\
\text { U.S. states }\end{array}$ & $\begin{array}{l}\text { - Mexican foreign-born noncitizens } \\
\text { college enrollment }(+) \\
\text { - } \quad \text { Mexican foreign-born noncitizens } \\
\text { educational attainment }(+) \\
\text { - Native-born college enrollment }(0)\end{array}$ \\
\hline $\begin{array}{l}\text { Chin and Juhn } \\
(2010)\end{array}$ & $\begin{array}{l}\text { States with } \\
\text { in-state tuition } \\
\text { regardless of } \\
\text { immigration } \\
\text { status }\end{array}$ & $\begin{array}{l}\text { Difference-in- } \\
\text { differences }\end{array}$ & $\begin{array}{l}2000-2005 \\
\text { U.S. states }\end{array}$ & $\begin{array}{l}\text { - Mexican foreign-born noncitizen men } \\
\text { college enrollment }(+) \\
\text { - Other foreign-born noncitizen college } \\
\text { enrollment }(0)\end{array}$ \\
\hline Flores (2010) & $\begin{array}{l}\text { States with } \\
\text { in-state tuition } \\
\text { regardless of } \\
\text { immigration } \\
\text { status }\end{array}$ & $\begin{array}{l}\text { Difference-in- } \\
\text { differences }\end{array}$ & $\begin{array}{l}\text { 1998-2005 } \\
\text { U.S. states }\end{array}$ & $\begin{array}{l}\text { - Latino foreign-born noncitizens } \\
\text { college enrollment (+) } \\
\text { - Minority (Latinos, blacks, and Asians) } \\
\text { U.S. citizens college enrollment (0) }\end{array}$ \\
\hline Koohi (2013) & $\begin{array}{l}\text { States with } \\
\text { in-state tuition } \\
\text { regardless of } \\
\text { immigration } \\
\text { status }\end{array}$ & $\begin{array}{l}\text { Difference-in- } \\
\text { differences }\end{array}$ & $\begin{array}{l}2001-2011 \\
\text { U.S. states }\end{array}$ & $\begin{array}{l}\text { Mexican foreign-born noncitizens } \\
\text { college enrollment }(+) \\
\text { - Mexican foreign-born noncitizens } \\
\text { high school dropout rate }(-) \\
\text { - Mexican foreign-born noncitizens } \\
\text { teenage birthrates }(-)\end{array}$ \\
\hline $\begin{array}{l}\text { Amuedo-Dorantes } \\
\text { and Sparber (2014) }\end{array}$ & $\begin{array}{l}\text { States with } \\
\text { in-state tuition } \\
\text { regardless of } \\
\text { immigration } \\
\text { status }\end{array}$ & $\begin{array}{l}\text { Difference-in- } \\
\text { differences }\end{array}$ & $\begin{array}{l}1998-2012 \\
\text { U.S. states }\end{array}$ & $\begin{array}{l}\text { - } \quad \text { Mexican foreign-born noncitizens } \\
\text { college enrollment }(+) \\
\text { - Other foreign-born noncitizens } \\
\text { college enrollment }(-) \\
\text { - } \quad \text { Native-born college enrollment }(0) \\
\text { - Tuition at flagship schools }(+) \\
\text { - Tuition at other colleges }(0) \\
\end{array}$ \\
\hline $\begin{array}{l}\text { Bozick and Miller } \\
(2014)\end{array}$ & $\begin{array}{l}\text { States with } \\
\text { in-state tuition } \\
\text { regardless of } \\
\text { immigration } \\
\text { status }\end{array}$ & $\begin{array}{l}\text { Difference-in- } \\
\text { differences }\end{array}$ & $\begin{array}{l}1997-2010 \\
\text { U.S. states }\end{array}$ & $\begin{array}{l}\text { - Mexican foreign-born noncitizens } \\
\text { high school enrollment }(+) \\
\text { - Native-born high school enrollment } \\
(0)\end{array}$ \\
\hline Potochnick (2014) & $\begin{array}{l}\text { States with } \\
\text { in-state tuition } \\
\text { regardless of } \\
\text { immigration } \\
\text { status }\end{array}$ & $\begin{array}{l}\text { Difference-in- } \\
\text { differences }\end{array}$ & $\begin{array}{l}\text { 1998-2011 } \\
\text { U.S. states }\end{array}$ & $\begin{array}{l}\text { Mexican foreign-born noncitizens } \\
\text { dropout rate }(-)\end{array}$ \\
\hline $\begin{array}{l}\text { Bozick, Miller, and } \\
\text { Kaneshiro (2015) }\end{array}$ & $\begin{array}{l}\text { States with } \\
\text { in-state tuition } \\
\text { regardless of } \\
\text { immigration } \\
\text { status }\end{array}$ & $\begin{array}{l}\text { Difference-in- } \\
\text { differences }\end{array}$ & $\begin{array}{l}\text { 1997-2010 } \\
\text { U.S. states }\end{array}$ & $\begin{array}{l}\text { Mexican foreign-born noncitizens } \\
\text { college enrollment }(+) \\
\text { - Other foreign-born noncitizens } \\
\text { college enrollment }(0) \\
\text { - Native-born college enrollment }(0)\end{array}$ \\
\hline
\end{tabular}

NOTE: $+/-/ 0$ = indicates increase / decrease / no effect, respectively, for the outcome in states with unrestrictive instate tuition policy or other financial aid. 
All of these difference-in-differences studies focus on the average impacts across all states of adopting an unrestrictive in-state tuition policy within a given period of time. One challenge these studies share is that they do not have data that identify unauthorized immigrants. Thus, outcomes are considered for potential unauthorized immigrants, such as foreign-born noncitizens as a group or from specific countries (e.g., Mexico).

\section{Effects on Educational Outcomes of Immigrants}

A consistent finding across these studies, in accord with our expectations, is that making in-state tuition available regardless of legal status increases the college enrollment of foreign-born noncitizens, the group that proxies for unauthorized immigrants. Those studies that cover a narrower range of years tend to find more-limited effects, both because fewer states had adopted the policy during the time period (so there is less policy variation) and because it may take time for the policy impact to manifest in college-going behavior. For example, Chin and Juhn (2010) cover the 2000-2005 period and find effects on college enrollment are limited to foreign-born noncitizen Mexican men. Studies such as Koohi (2013), Amuedo-Dorantes and Sparber (2014), and Bozick, Miller, and Kaneshiro (forthcoming) capture changes from 2010 to 2012 and find larger effects, with an increase in college enrollments ranging from 1.9 percentage points (Koohi, 2013) to 6 percentage points (Amuedo-Dorantes et al., 2014). ${ }^{11}$

Several studies find as large an effect (or even larger) on the behavior of high school students - specifically, staying in school to degree completion. Some students who would have otherwise dropped out feel encouraged to stay in school, given the prospect of affordable college. Koohi (2013), Bozick and Miller (2014), and Potochnick (2014) all find an increase in high school enrollment or a decrease in high school dropout among likely unauthorized immigrants. The magnitude of the effect on high school enrollment or dropout varies across studies, from 3 percentage points in Koohi (2013) to 11 percentage points in Potochnick (2014). Koohi (2013) also finds a significant reduction in teen birthrates among Mexican foreign-born noncitizens, which further suggests an influence of the reduced cost of higher education on other aspects of behavior.

\section{Effects on Educational Outcomes of Natives}

If enrollment at the high school or college level is constrained (i.e., a fixed number of seats) or there is a limited supply of tuition subsidies, a policy that increases enrollment of unauthorized immigrants could reduce enrollments for other groups, such as native-born students and legally resident immigrants. Our framework allows for this possibility and several of the studies reviewed in Table 3.12 examine this empirically by estimating the same difference-in-differences models for other groups. None of the studies considering such effects found statistically

\footnotetext{
${ }^{11}$ However, given that legal status is not observable and that studies use the noncitizen foreign born as a proxy, the measured effects are likely biased downward; i.e., the effects for the unauthorized immigrant population are likely to be larger than those estimated in the studies.
} 
significant impacts. For example, Flores (2010) examined the impact of unrestrictive in-state tuition policy on college enrollment of minority U.S. citizens and found no impact. Kaushal (2008), Amuedo-Dorantes and Sparber (2014), Bozick and Miller (2014), and Bozick, Miller, and Kaneshiro (forthcoming) study the impact of in-state tuition policy on the high school or college enrollment of the native-born population, and all find a zero or statistically insignificant effect.

\section{Fiscal Effects}

In their consideration of making in-state tuition available regardless of legal status, none of the studies summarized in Table 3.12 consider the net impact on state subsidies for colleges and universities or on the cost of public education more generally. Making in-state tuition more widely available will mean public higher education institutions will forgo some tuition from students who would have attended at the undiscounted rate. If enrollment is not constrained and tuition subsidies are not limited, we would expect an increase in public higher education subsidies and for total tuition revenue to increase with the rise in enrollment (although costs will increase as well). Thus, the net effect is ambiguous. Several of the studies listed in Table 3.12 examine the effects on tuition or the fiscal effects of making in-state tuition available regardless of immigration status, but the findings are limited. Kaushal (2008) concludes that the fiscal impact is indeterminate. Amuedo-Dorantes and Sparber (2014) find that tuition at flagship universities increases as a result of allowing in-state tuition regardless of immigration status, but tuition at other public institutions is not affected.

\section{Completed Framework}

Table 3.13 represents the completed framework for analyzing the impacts of making in-state tuition or other financial aid available regardless of immigration status. (Again, the direction of the effects would be reversed if unauthorized immigrants became ineligible for in-state tuition.) The table records the two main impacts of the policy: on the number of immigrants in the state and on the educational attainment of immigrants. Impacts are recorded for the key stakeholders: unauthorized immigrants themselves, other workers, employers, and state and local governments. (As with earlier tables, the stakeholder columns do not include stakeholder groups outside of the adopting state.)

We now summarize the impacts and the associated cost and benefits that should be taken into account when conducting a CBA of allowing (or prohibiting) in-state tuition for unauthorized immigrants. 
Table 3.13. Accounting for Potential Costs and Benefits of Providing Access to In-State Tuition or Other Financial Aid Regardless of Immigration Status

\begin{tabular}{|c|c|c|c|c|}
\hline & \multicolumn{4}{|c|}{ Stakeholders } \\
\hline $\begin{array}{l}\text { Potential Main } \\
\text { Impacts }\end{array}$ & $\begin{array}{l}\text { Unauthorized } \\
\text { Immigrants }\end{array}$ & $\begin{array}{c}\text { Authorized } \\
\text { Immigrants and } \\
\text { Native-Born }\end{array}$ & Employers & $\begin{array}{l}\text { State and Local } \\
\text { Government }\end{array}$ \\
\hline $\begin{array}{l}\text { Increased number } \\
\text { of unauthorized } \\
\text { immigrants }\end{array}$ & $\begin{array}{c}+ \text { or - } \\
\text { depending on } \\
\text { difference in skill mix } \\
\text { between those who } \\
\text { arrive and current } \\
\text { residents }\end{array}$ & $\begin{array}{l}+ \text { or - } \\
\text { depending on skill } \\
\text { level and changes in } \\
\text { relative wages }\end{array}$ & $\begin{array}{l}+ \text { or - } \\
\text { depending on skill } \\
\text { mix of employees }\end{array}$ & $\begin{array}{l}+ \text { or - } \\
\text { depending on net } \\
\text { fiscal impact of } \\
\text { unauthorized who } \\
\text { arrive }\end{array}$ \\
\hline \multirow[t]{2}{*}{$\begin{array}{l}\text { Increased } \\
\text { educational } \\
\text { attainment of } \\
\text { unauthorized } \\
\text { immigrants }\end{array}$} & \multirow[t]{2}{*}{$\begin{array}{c}+ \\
\text { from lower out-of- } \\
\text { pocket costs of } \\
\text { enrolling in college } \\
\text { and higher human } \\
\text { capital attainment } \\
\text { from attending } \\
\text { college }\end{array}$} & $\begin{array}{c}0 \text { or - } \\
\text { depending on net } \\
\text { increase in human } \\
\text { capital attainment if } \\
\text { access to subsidies } \\
\text { is capped and } \\
\text { spaces are now } \\
\text { freed up }\end{array}$ & \multirow[t]{2}{*}{$\begin{array}{l}+ \text { or - } \\
\text { depending on net } \\
\text { effect on skill mix of } \\
\text { workforce, skill mix } \\
\text { of employees, and } \\
\text { wage structure }\end{array}$} & $\begin{array}{c}- \text { or } 0 \\
\text { for higher education } \\
\text { subsidies depending } \\
\text { on change in } \\
\text { subsidized } \\
\text { enrollment }\end{array}$ \\
\hline & & $\begin{array}{l}+ \text { or - } \\
\text { depending on skill } \\
\text { level and changes in } \\
\text { relative wages }\end{array}$ & & $\begin{array}{c}+ \text { or } 0 \\
\text { depending on net } \\
\text { change in college- } \\
\text { educated }\end{array}$ \\
\hline
\end{tabular}

NOTES: + / - / 0 = favorable, unfavorable, or neutral outcome, respectively, from perspective of stakeholder. Green shading indicates evidence for the main impacts; yellow indicates little or no evidence.

- Increased number of unauthorized immigrants. Although we did not identify empirical evidence in favor or against this hypothesized effect, it is important that a CBA consider the possibility of there being a significant change in the number of unauthorized immigrants living in the state. This type of effect was found for the restrictive policies discussed earlier in the section (e.g., immigration-related law enforcement). An increase in the number of immigrants associated with making in-state tuition available would produce effects on wages for both immigrants and natives depending on the difference in the skill mix under the status quo versus the new entrants. There are also uncertain impacts on employers and state coffers.

- Increased number of skilled workers in the medium and long term. The evidence we have reviewed indicated increases in immigrant education, with no crowding out of education for native-born individuals. Thus, this domain of impact should be accounted for in a CBA. The increase in human capital will generate net benefits for the individuals themselves. Authorized immigrants and the native-born may experience benefits or costs depending on whether subsidized enrollments are fixed or expand to meet any increase in demand. Similar arguments apply for calculating the benefits and costs for higher education budgets. The consequences for employers depend on the change in the skill mix. 


\section{Framework Applied to Driver's License Eligibility}

In Chapter Two, we also featured state policy with respect to the eligibility of unauthorized immigrants for a driver's license or other form of identification. Under the status quo, unauthorized immigrants would not qualify for a driver's license, so the change is toward an unrestrictive policy (see Table 3.2). In the remainder of this section, we first highlight the primary and secondary expected effects from this policy. We then discuss the one empirical study that considers the impact of state driver's license policy on insurance coverage. We conclude by presenting the completed framework, largely based on hypothesized effects.

\section{Expected Effects}

Table 3.14 shows the expected policy effect, common to all policies we consider, on the number of unauthorized immigrants. As with the in-state tuition policy, states that allow unauthorized immigrants to obtain a state-issued license or identification are adopting an unrestrictive policy. As noted in Table 3.14, we would expect an increase in unauthorized immigrants and the associated secondary effects on wages, economic output, and state and local budgets discussed earlier.

Table 3.14. Potential Impacts of Providing Driver's Licenses Regardless of Immigration Status

\begin{tabular}{|c|c|}
\hline Potential Main Impacts & Potential Secondary Impacts \\
\hline $\begin{array}{l}\text { Increased number of } \\
\text { unauthorized immigrants }\end{array}$ & $\begin{array}{l}\text { - Decrease wages of unskilled authorized workers/increased wages of } \\
\text { - } \quad \text { Increased economic output/increase price of some services } \\
\text { - Fiscal impact unclear (both increased tax revenue and increased } \\
\text { government expenditures) }\end{array}$ \\
\hline $\begin{array}{l}\text { Unauthorized immigrants can } \\
\text { obtain auto insurance }\end{array}$ & $\begin{array}{l}\text { - Improved driving safety and reduced automobile accidents among } \\
\text { - Inauthorized immigrants } \\
\text { - Insurease in insured drivers among unauthorized immigrants and reduced } \\
\text { - Increase in unauthorized immigrants in jobs requiring a driver's license }\end{array}$ \\
\hline $\begin{array}{l}\text { Unauthorized immigrants can } \\
\text { access other services requiring } \\
\text { identification (e.g., banking) }\end{array}$ & $\begin{array}{l}\text { - Value of new services for unauthorized immigrants without license } \\
\text { - Value of new services for firms providing the service }\end{array}$ \\
\hline Cost to implement the policy & - Net cost to government to issue driver's licenses net of fees \\
\hline
\end{tabular}

The table shows a second main impact, which is the increased access to auto insurance on the part of unauthorized immigrants. The consequences in terms of increased insurance coverage, reduced premiums, and greater safety are among the most common arguments for states adopting this policy (Pew Charitable Trusts, 2015). While it is plausible to assume that insurance coverage rates would rise as more unauthorized immigrants obtained driver's licenses and that premiums would decline as the pool of insured drivers increased, it is not evident that road safety would necessarily improve as well. Whether or not insured drivers are safer than uninsured drivers depends on the incentive properties of the insurance contract, such as fault versus no-fault 
systems, size of the deductible, and the link between a driver's history of traffic violations and accidents and the insurance premium (i.e., experience rating). These features have implications for the extent to which moral hazard is addressed through the structure of the insurance contract.

A third domain of impact is that unauthorized immigrants may be able to access services and other supports where having a state-issued identification is a requirement (Mathema, 2015). The banking sector is one such example where establishing a banking account or obtaining a loan would require identification. This reduction in economic and social isolation would mainly benefit unauthorized immigrants themselves, although it also may affect the service provider, to a lesser extent. $^{12}$

Finally, there is a cost to the public sector associated with issuing driver's licenses, although states typically charge a fee that may be more than, just, or less than sufficient to cover the administrative cost.

\section{Empirical Evidence}

As noted, we identified just one study that provides direct evidence on the impact of state policy regarding driver's licenses for unauthorized immigrants. In particular, as shown in Table 3.16, Cáceres and Jameson (2015) consider the effect on insurance expenditures per capita of states that restrict access to driver's licenses relative to states that have no such restrictions (the opposite policy and counterfactual listed in Table 3.2). Using aggregate data from 1995 to 2012 and a model with state and time fixed effects, the study finds that more restrictive driver's license policies raise the per capita annual insurance premium cost, consistent with the effect in Table 3.14 (although with the reverse policy), with an annual effect of about $\$ 47$.

In contrast to several of the other policy areas, we did not identify any research that examined the impact of state driver's license policy on the number of unauthorized immigrants or on the number of other relevant groups in the state. Given this paucity of evidence, any CBA of state driver's license policy would need to allow for the current uncertainty regarding such policy impacts.

Table 3.15. Studies Assessing Impacts of Providing Driver's Licenses Regardless of Immigration Status

\begin{tabular}{lcccc}
\hline Study & Policy Examined & Method & $\begin{array}{c}\text { Years and } \\
\text { Geography } \\
\text { Covered }\end{array}$ & $\begin{array}{c}\text { Estimated Effect of Restricting } \\
\text { Driver's License Access }\end{array}$ \\
\hline $\begin{array}{l}\text { Cáceres and } \\
\text { Jameson (2015) }\end{array}$ & $\begin{array}{c}\text { States that exclude } \\
\text { unauthorized } \\
\text { immigrants' access } \\
\text { to driver's licenses }\end{array}$ & $\begin{array}{c}\text { State and } \\
\text { year fixed } \\
\text { effects }\end{array}$ & $\begin{array}{c}\text { 1995-2012 } \\
\text { U.S. states }\end{array}$ & $\begin{array}{l}\text { Real average annual insurance } \\
\text { premiums (+) }\end{array}$ \\
\hline
\end{tabular}

NOTE: $+/-/ 0$ = indicates increase / decrease / no effect, respectively, for the outcome in states with restrictive driver's license policy.

\footnotetext{
12 The increased demand for the services that unauthorized immigrants would consume could result in price changes (depending on the supply side of the market) that would have implications for authorized immigrants and natives who also consume the services.
} 


\section{Completed Framework}

Even in the absence of substantial empirical evidence, we can complete the cost-benefit framework for considering the consequences for various stakeholders from allowing unauthorized immigrants to access driver's licenses, building from Table 3.14. Table 3.16 displays the resulting framework. A CBA of allowing driver's license access for unauthorized immigrants should consider the following impacts:

- Increased number of unauthorized immigrants. The first row mirrors the entry in Table 3.13 for in-state tuition because both are unrestrictive policies toward unauthorized immigrants.

- Unauthorized immigrants can obtain auto insurance. Providing access to the auto insurance market will produce net benefits or costs for the unauthorized immigrants themselves, depending on the market price and the value to the consumer of the insurance. If being insured improves auto safety, authorized immigrants and native-born persons will benefit from a safer driving environment. Employers may benefit as more

Table 3.16. Accounting for Potential Costs and Benefits of Providing Driver's Licenses Regardless of Immigration Status

\begin{tabular}{|c|c|c|c|c|}
\hline \multirow[b]{2}{*}{$\begin{array}{l}\text { Potential Main } \\
\text { Impacts }\end{array}$} & \multicolumn{4}{|c|}{ Stakeholders } \\
\hline & $\begin{array}{l}\text { Unauthorized } \\
\text { Immigrants }\end{array}$ & $\begin{array}{c}\text { Authorized } \\
\text { Immigrants and } \\
\text { Native-Born }\end{array}$ & Employers & $\begin{array}{l}\text { State and Local } \\
\text { Government }\end{array}$ \\
\hline $\begin{array}{l}\text { Increased number } \\
\text { of unauthorized } \\
\text { immigrants }\end{array}$ & $\begin{array}{c}+ \text { or - } \\
\text { depending on } \\
\text { difference in skill } \\
\text { mix between those } \\
\text { who arrive and } \\
\text { current residents }\end{array}$ & $\begin{array}{l}+ \text { or - } \\
\text { depending on skill } \\
\text { level and changes in } \\
\text { relative wages }\end{array}$ & $\begin{array}{c}+ \text { or } 0 \\
\text { depending on skill } \\
\text { mix of employees }\end{array}$ & $\begin{array}{l}+ \text { or }- \\
\text { depending on net } \\
\text { fiscal impact of } \\
\text { unauthorized who } \\
\text { arrive }\end{array}$ \\
\hline $\begin{array}{l}\text { Unauthorized } \\
\text { immigrants can } \\
\text { obtain auto } \\
\text { insurance }\end{array}$ & $\begin{array}{l}+ \text { or - } \\
\text { depending on cost } \\
\text { of auto insurance } \\
\text { versus value to } \\
\text { consumer }\end{array}$ & $\begin{array}{c}+ \\
\text { from improved } \\
\text { driving safety and } \\
\text { reduced auto } \\
\text { insurance premiums }\end{array}$ & $\begin{array}{c}+ \\
\text { from increased } \\
\text { share of workforce } \\
\text { with capacity to } \\
\text { drive }\end{array}$ & $\begin{array}{c}0 \text { or }+ \\
\text { depending on any } \\
\text { increased revenue } \\
\text { associated with } \\
\text { increased auto } \\
\text { insurance coverage }\end{array}$ \\
\hline $\begin{array}{l}\text { Unauthorized } \\
\text { immigrants can } \\
\text { access other } \\
\text { services requiring } \\
\text { identification (e.g., } \\
\text { banking) }\end{array}$ & $\begin{array}{c}+ \\
\text { from increased } \\
\text { access to services }\end{array}$ & Not applicable & $\begin{array}{c}+ \\
\text { from increased } \\
\text { demand for services }\end{array}$ & $\begin{array}{c}0 \text { or }+ \\
\text { depending on any } \\
\text { increased revenue } \\
\text { associated with any } \\
\text { increased services } \\
\text { accessed }\end{array}$ \\
\hline $\begin{array}{l}\text { Cost to implement } \\
\text { the policy }\end{array}$ & $\begin{array}{l}- \\
\text { from fees paid for } \\
\text { licenses }\end{array}$ & Not applicable & Not applicable & $\begin{array}{c}+ \text { or }- \\
\text { depending size of } \\
\text { license fee relative } \\
\text { to cost to issue }\end{array}$ \\
\hline
\end{tabular}

NOTES: + / - / 0 = favorable, unfavorable, or neutral outcome, respectively, from perspective of stakeholder. Green shading indicates evidence for the main impacts; yellow indicates little or no evidence. 
potential employees can drive, if required for their job. The fiscal impact is expected to be neutral or positive if the state generates revenue from the auto insurance industry (e.g., sales taxes). If the driver's license fees cover the administrative costs of issuing the licenses, states could benefit fiscally as well.

- Unauthorized immigrants can access other services requiring identification. The same arguments apply to the third row if unauthorized immigrants gain access to markets where they previously had none (e.g., financial services). This would be expected to provide a net welfare gain for unauthorized immigrants themselves, a gain for employers through increased demand for the services, and a potential net positive gain for local and state governments.

- Cost to implement the policy. Any fee charged for issuing a license is a transfer from the recipient (who experiences a cost) to the issuing government agency (which experiences a benefit). Aggregated across stakeholders, the net effect will equal the costs to the public sector of issuing the license. From the government perspective, the net effect may be positive, negative, or zero depending on whether the fee covers the administrative cost to issue each license.

\section{Framework Applied to Health Care Access for Pregnant Women and Children}

Chapter Two reviewed the state-level immigration policies that are related to health care policy. Two main policies were featured: the availability of subsidized prenatal care and of health insurance coverage for children, regardless of immigration status. In the absence of these policy provisions, unauthorized immigrants are not eligible for publicly subsidized health care or health insurance (e.g., through Medicaid or CHIP). Thus, as indicated in Table 3.2, our discussion assumes that the policy change is unrestrictive toward unauthorized immigrants by making subsidized prenatal care or health insurance available without reference to immigration status. As with previous sections, we begin by discussing the expected impacts of these health-related policies, where we treat access to prenatal care and child health insurance interchangeably. We then review the available literature assessing the impact of these policies, which turns out to be very limited in this case. For this reason, the cost-benefit framework we present at the end of the section identifying potential costs and benefits currently has little empirical support.

\section{Expected Effects}

As shown in Table 3.17, and as with other unrestrictive policies, an expected main effect of extending access to subsidized prenatal care or child health insurance will be to increase the number of unauthorized immigrants with the corresponding secondary effects on wages, economic output, and state and local budgets. 
Table 3.17. Potential Impacts of Extending Access to Subsidized Prenatal Care and Child Health Insurance for Unauthorized Immigrants

\begin{tabular}{|c|c|}
\hline Potential Main Impacts & Potential Secondary Impacts \\
\hline $\begin{array}{l}\text { Increased number of } \\
\text { unauthorized immigrants }\end{array}$ & $\begin{array}{l}\text { - Decreased wages of unskilled authorized workers/increased wages of } \\
\text { skilled authorized workers } \\
\text { - Increased economic output/increase price of some services } \\
\text { - Fiscal impact unclear (both increased state tax revenue and increased } \\
\text { state government expenditures) }\end{array}$ \\
\hline $\begin{array}{l}\text { Improved health status of } \\
\text { unauthorized immigrant pregnant } \\
\text { women and children }\end{array}$ & $\begin{array}{l}\text { - Improved health and other life course outcomes (e.g., earnings) for } \\
\text { - Imauthorized immigrant pregnant women and new mothers } \\
\text { performance, earnings) for unauthorized immigrant children or of the } \\
\text { (likely U.S. citizen) children of unauthorized immigrant mothers } \\
\text { - Improved health and other life course outcomes (e.g., earnings) for other } \\
\text { state residents if improved maternal and child health includes } \\
\text { communicable diseases } \\
\text { - Fiscal impact unclear (increased cost for subsidized prenatal care and } \\
\text { health insurance coverage; expected decreased cost for health care } \\
\text { utilization) } \\
\text { Financial impact on hospitals and health care providers unclear } \\
\text { (increased revenue because of increase in the insured; reduced revenue } \\
\text { because of improved health of pregnant women, children, and other state } \\
\text { residents) }\end{array}$ \\
\hline
\end{tabular}

The second main expected impact would be on the health of the pregnant women who receive subsidized prenatal care (as well as the health of their children) and the health of the children who receive health insurance coverage. The expected secondary impacts are shown in the second column of Table 3.17. In particular, research has demonstrated the importance of access to prenatal care services for the health of the mother and her child (Alexander and Korenbrot, 1995; Korenbrot et al., 2002; Rossin-Slater, 2015). For low-income women, the provision of subsidized care has been shown to reduce the incidence of low birth weight and lower infant mortality (Currie and Gruber, 1996a, 1996b). A related literature shows the favorable health effects for low-income children who receive access to subsidized health insurance through Medicaid or CHIP (Levine and Schanzenbach, 2009; Meyer and Wherry, 2012; Cohodes et al., 2014; Goodman-Bacon, 2015; Miller and Wherry, 2015).

For children, there are potential longer-term benefits associated with improved health during childhood and adolescence (Rossin-Slater, 2015), whether because of better birth outcomes resulting from prenatal care or the improved health that results from access to preventive and routine medical care. For instance, Black, Devereux, and Salvanes (2007) show that higherweight newborns eventually have better education and labor market outcomes. These results stand even after controlling for other factors by comparing outcomes of identical twins, suggesting that low birth weight can have long-term impacts. Case and Paxson (2008) demonstrate that health status in adolescence affects economic outcomes in adulthood, such as earnings, since children with good health develop higher cognitive ability, which, itself, affects education attainment and labor market outcomes. 
There also may be public health benefits for other residents in the state if there is a reduction in communicable diseases as a result of the expanded health care subsidies for unauthorized pregnant women and children. Evidence indicates, for example, that uninsured children are less likely to be up-to-date on all vaccinations and that reduced population-level vaccination rates can lead to outbreaks of influenza, measles, and other communicable diseases (Institute of Medicine, 2009; NILC, 2014).

Finally, the secondary impacts discussed here potentially have implications for the net effect on government finances and the net effect on hospitals and other health care providers. In both cases, the net effect is uncertain because of countervailing effects. For the state and local governments, the health care and health insurance subsidies will raise expenditures, but there may reductions in health care utilization because of improved health that offset those added costs. For health care providers, health care utilization would be expected to rise as more lowincome pregnant women and children gain access to health care, but again the improvements in health may lower the net revenue to providers.

\section{Empirical Evidence}

Our review identified only one study that can be considered an impact study of policies pertaining to access to prenatal care or health insurance coverage for unauthorized immigrants (see Table 3.18). In particular, Kuiper et al. (1999) investigate the effects on the prevalence of sexually transmitted infections (STIs) of the 1996 California law that restricted unauthorized pregnant women from accessing publicly funded prenatal health services. Rather than providing an empirical ex-post assessment of the effect of the introduction of the policy, the study combines information on the number of unauthorized immigrant mothers who would now receive care under the policy with empirical estimates of the prevalence of STIs among women with no prenatal care. The authors conclude that the prevalence of STIs in the overall population increases when unauthorized immigrant women are restricted from accessing prenatal health care.

Table 3.18. Studies Assessing Impacts of Unauthorized Immigrants' Access to Subsidized Prenatal Care

\begin{tabular}{lcccc}
\hline Study & Policy Examined & Method & $\begin{array}{c}\text { Years and } \\
\text { Geography } \\
\text { Covered }\end{array}$ & $\begin{array}{c}\text { Estimated Effect of Restricting Access } \\
\text { to Subsidized Prenatal Care }\end{array}$ \\
\hline $\begin{array}{l}\text { Kuiper et al. } \\
(1999)\end{array}$ & $\begin{array}{c}\text { 1996 CA law restricting } \\
\text { unauthorized immigrants' } \\
\text { access to prenatal care }\end{array}$ & $\begin{array}{c}\text { Simulation } \\
\text { analysis }\end{array}$ & $\begin{array}{c}1995 \\
\text { California }\end{array}$ & $\begin{array}{c}\text { Prevalence of sexually transmitted } \\
\text { infections }(+)\end{array}$ \\
\hline NOTE: $+/-/ 0=$ favorable, unfavorable, or neutral outcome from restrictive policy regarding access to prenatal care.
\end{tabular}




\section{Completed Framework}

The completed framework for health care access is shown in Table 3.19. Given the paucity of research on the impact of state policies to provide subsidized prenatal care and children's health insurance coverage regardless of immigration status, we view the potential impacts across stakeholders as less certain (shaded yellow). Nevertheless, a comprehensive CBA would account for the following:

- Increased number of unauthorized immigrants. The first row in Table 3.19 is consistent with those for the two other unrestrictive state policies for in-state tuition and driver's licenses, with uncertain gains or losses depending on the nature of the impacts.

- Improved health status of unauthorized immigrant pregnant women and children. The second row is an entry specific to extending access to publicly subsidized health care or health insurance. The row entries indicate positive net benefits for unauthorized immigrants, given the expected improvements in their own health, as well as positive net benefits for authorized immigrants and the native-born from the associated public health improvements. The effects on employers, specifically hospitals and health care providers, are uncertain, as it depends on the net change in health care spending among the newly insured. The fiscal effects are likewise uncertain, as states will pay more for subsidized health care or health insurance coverage but may face lower costs from the improved access to health care and improved population health.

Table 3.19. Accounting for Potential Costs and Benefits of Extending Access to Subsidized Prenatal Care and Child Health Insurance for Unauthorized Immigrants

\begin{tabular}{|c|c|c|c|c|}
\hline & \multicolumn{4}{|c|}{ Stakeholders } \\
\hline $\begin{array}{l}\text { Potential Main } \\
\text { Impacts }\end{array}$ & $\begin{array}{l}\text { Unauthorized } \\
\text { Immigrants }\end{array}$ & $\begin{array}{c}\text { Authorized } \\
\text { Immigrants and } \\
\text { Native-Born }\end{array}$ & Employers & $\begin{array}{l}\text { State and Local } \\
\text { Government }\end{array}$ \\
\hline $\begin{array}{l}\text { Increased number } \\
\text { of unauthorized } \\
\text { immigrants }\end{array}$ & $\begin{array}{c}+ \text { or - } \\
\text { depending on } \\
\text { difference in skill } \\
\text { mix between those } \\
\text { who arrive and } \\
\text { current residents }\end{array}$ & $\begin{array}{l}+ \text { or - } \\
\text { depending on skill } \\
\text { level and changes in } \\
\text { relative wages }\end{array}$ & $\begin{array}{c}+ \text { or } 0 \\
\text { depending on skill } \\
\text { mix of employees }\end{array}$ & $\begin{array}{l}+ \text { or }- \\
\text { depending on net } \\
\text { fiscal impact of } \\
\text { unauthorized who } \\
\text { arrive }\end{array}$ \\
\hline \multirow[t]{2}{*}{$\begin{array}{l}\text { Improved health } \\
\text { status of } \\
\text { unauthorized } \\
\text { immigrant } \\
\text { pregnant women } \\
\text { and children }\end{array}$} & \multirow[t]{2}{*}{$\begin{array}{c}+ \\
\text { from improved } \\
\text { health in short term } \\
\text { and longer term }\end{array}$} & $\begin{array}{c}+ \\
\text { from improved } \\
\text { health in short term } \\
\text { and longer term for } \\
\text { U.S. citizen children } \\
\text { born to unauthorized } \\
\text { immigrant mothers }\end{array}$ & \multirow{2}{*}{$\begin{array}{c}+ \text { or }- \\
\text { for hospitals and } \\
\text { health care } \\
\text { providers depending } \\
\text { on net health care } \\
\text { spending of } \\
\text { unauthorized who } \\
\text { receive subsidized } \\
\text { prenatal care and } \\
\text { health insurance }\end{array}$} & \multirow[t]{2}{*}{$\begin{array}{c}+ \text { or - } \\
\text { depending on net } \\
\text { fiscal impact of } \\
\text { unauthorized who } \\
\text { receive subsidized } \\
\text { prenatal care and } \\
\text { health insurance }\end{array}$} \\
\hline & & $\begin{array}{c}+ \\
\text { from improved } \\
\text { public health } \\
\text { (e.g., reduction in } \\
\text { communicable } \\
\text { disease) }\end{array}$ & & \\
\hline
\end{tabular}

NOTES: + / - / 0 = favorable, unfavorable, or neutral outcome, respectively, from perspective of stakeholder. Green shading indicates evidence for the main impacts; yellow indicates little or no evidence. 



\section{Analysis of Existing CBAs of State-Level Immigration Policy}

In Chapter Three, we developed a cost-benefit framework for each of the major policies adopted by states with regard to unauthorized immigrants. One feature of the completed frameworks we developed (see Tables 3.6, 3.9, 3.13, 3.16, and 3.19 in the previous chapter) is that the expected effects in any one cell of the impact matrix are often ambiguous. Further, for any given stakeholder (column in the matrix), the expected effects may be both favorable and unfavorable, so that the total net benefit is not clear. This same ambiguity applies to the aggregate net benefits for society as a whole - the sum of the effects across all stakeholders. Thus, a complete assessment of the costs and benefits of a given state-level immigration-related policy must be determined by implementing a CBA, one that accounts for the impacts in each of the cells of the cost-benefit framework and determines the economic value associated with each impact.

One use of the series of frameworks, therefore, is to guide the development of future CBAs of these policies. Each framework provides a template for identifying the potential areas of impact for a given policy and how those impacts may affect different stakeholders. Analysts could then identify empirical literature, such as the studies reviewed in Chapter Three, to determine the likely direction and magnitudes of the expected effects. Another application of the frameworks is to evaluate prior CBAs in terms of their completeness - whether they capture all potential costs and benefits for each stakeholder of interest - and consistency with existing empirical evidence of policy impacts. Because conducting a series of new CBAs is beyond the scope of this study, we take the latter approach and use the frameworks to assess the quality of CBAs that have previously been conducted.

In particular, we focus on two CBAs that assess the costs and benefits of state-level immigration-related policies described in Chapter Two: one specific to in-state tuition policy (Gindling and Mandell, 2012, 2015); the other focused on a policy denying free prenatal care to pregnant women who are unauthorized immigrants (Lu et al., 2000). These two studies were identified as part of a literature search, which we describe in the next section. We then assess each of the CBAs by comparing the analytic approach of the CBA with the appropriate framework developed in Chapter Three.

\section{Existing Literature on Costs and Benefits of State-Level Immigration Policies}

Table 4.1 shows a set of characteristics associated with a high-quality formal CBA (Gramlich, 1990; Zerbe and Bellas, 2006; Karoly, 2012). In particular, a CBA would assess the costs and benefits of a given policy relative to a clear baseline (e.g., one where the policy of interest is not in place). The 
Table 4.1. Features of a Formal CBA

\begin{tabular}{|c|c|}
\hline Feature & Explanation \\
\hline Baseline & Policy change is compared with a well-defined baseline or alternative \\
\hline Costs & Comprehensive measurement of costs of implementing the policy change relative to the baseline \\
\hline Outcomes & Comprehensive measurement of impacts of implementing the policy change relative to the baseline \\
\hline $\begin{array}{l}\text { Economic } \\
\text { values }\end{array}$ & $\begin{array}{l}\text { For outcomes not denominated in dollars, economic values can be assigned (may be positive or } \\
\text { negative) }\end{array}$ \\
\hline Discounting & Dollar values in future years (associated with costs or outcomes) are discounted to the present \\
\hline $\begin{array}{l}\text { Perspective } \\
\text { and } \\
\text { stakeholders }\end{array}$ & $\begin{array}{l}\text { The analysis has a clear perspective and economic values of outcomes are disaggregated by key } \\
\text { stakeholders (e.g., private sector versus public sector) }\end{array}$ \\
\hline
\end{tabular}

CBA would include a comprehensive measurement of the cost to implement the policy relative to the baseline, and it would measure the resulting policy impacts. When outcomes are not already denominated in dollars, economic values would be assigned to each area of impact. Summary measures, such as net benefits or benefit-cost ratio, would discount future dollar costs or benefits into present-value dollars. The analysis would have a well-defined perspective, such as the state government or society as a whole, either specific to the focal state or for the United States as a whole. Where feasible, results would be disaggregated into relevant stakeholder groups.

Using keyword terms, we conducted a literature search to identify illustrative formal CBAs of state-level immigration-related policies that could be analyzed as part of this study. ${ }^{1}$ Studies identified in the first stage were screened to identify those that met the following criteria: (1) the study analyzed one or more of the state-level policies reviewed in Chapter Two relative to a clear counterfactual; (2) the study employed a clear perspective, preferably the societal perspective; and (3) the study aimed to provide a comprehensive accounting and valuation of relevant costs and benefits of the focal policy. The first criterion ensured alignment with the focus of the rest of the study, while the second and third criteria provided us with CBAs that were sufficiently comprehensive.

As noted, our search yielded two formal CBAs that met our criteria. The studies that did not meet our criteria generally fell into two categories. First, a number of studies provided estimates of the net economic or fiscal cost of immigration at the state or national level (see references to these studies in Chapter Three). These studies do not examine the costs and benefits of a particular policy change, but rather consider the net economic costs to the public sector or to society as a whole that result from volume of immigration and the composition of the immigrant population (e.g., unauthorized

\footnotetext{
${ }^{1}$ The literature search encompassed the following bibliographic databases: EBSCO Academic Search Complete, EBSCO Business Search Complete, EconLit, Scopus, and World of Science. For any given policy (e.g., "omnibus" or specific pieces of legislation (e.g., SB 1070), "E-Verify," "employment verification," "in-state tuition," "identification," "health care," and "prenatal care"), we searched using combinations with the following terms: "immigrants," "immigration," "unauthorized immigrants," "unauthorized immigrants," "state," "impact," and "impacts." We also checked the references for the identified studies to identify studies that the search process may have missed.
} 
versus authorized). In these analyses, the implicit counterfactual is a baseline with no immigration or no unauthorized immigration. For example, Gans (2008) calculates the net fiscal and economic impacts of immigrants (regardless of legal status) in Arizona, tallying fiscal costs associated with education, health care, law enforcement, and other services delivered to immigrants, while also adding in economic contributions made by immigrants as consumers and workers. However, this study documents costs under the status quo, with an implicit counterfactual of no immigration. Other studies with a similar methodology are summarized in CBO (2007).

Second, another group of studies considers state-specific immigration-related policies and describes the potential impacts. Such studies typically emphasize either the benefits or the costs associated with the policy, often as part of supporting or opposing the policy change. Such analyses do not attempt to provide a full accounting of both favorable and unfavorable outcomes, nor do they attempt to quantify the dollar values of the expected impacts. Those that do assign dollar values often do not have an empirical basis for the estimates that are employed, either because they do not rely on the existing literature (such as the studies reviewed in Chapter Three) or the existing literature has yet to provide estimates of impacts in those areas.

For example, a policy brief by NILC (2011) delineates a set of arguments against mandating E-Verify in Louisiana, pointing to new costs to employers to comply, a growth in the underground economy, costly errors in the system affecting lawful immigrants and U.S. citizens, and lost government revenue. There is no effort to quantify the effects based on existing research, nor any reference to potential benefits. A series of policy briefs by the American Immigration Council and Center for American Progress (2011a, 2011b) for California, Michigan, and several other states likewise focuses exclusively on potential costs to workers, employers, and the public sector from an E-Verify mandate, but the stated unfavorable outcomes are not based on research quantifying E-Verify impacts in other states. As another example, Helmcamp and Cooper (2013) enumerate a set of expected benefits for Texas from making in-state tuition available to unauthorized immigrants, providing they meet several eligibility requirements. Again, the analysis is not intended to provide a complete accounting of costs and benefits, as there is no mention of potential unfavorable consequences.

As noted above, we identified two studies that met our criteria. Gindling and Mandell (2012, 2015) assess the costs and benefits of the Maryland Dream Act, which allowed access to in-state tuition for immigrants regardless of their legal status. Lu et al. (2000) examine the costs and benefits of California's Proposition 187, which prohibited publicly funded health care facilities from providing nonemergency care, including prenatal care, to unauthorized immigrants. We discuss each of these studies in turn.

\section{Assessment of a CBA of the Maryland Dream Act}

In May 2011, Maryland Governor Martin O’Malley signed SB 167, also known as the Maryland Dream Act. The legislation allows unauthorized immigrants to pay in-state tuition at Maryland 
colleges, providing they meet several requirements: attend a Maryland high school for at least three years, receive a high school diploma or equivalent, comply with the selective service registration requirement, demonstrate that they or their parents filed taxes during the three years in high school and any intervening years since high school graduation, and file an application for permanent residency within 30 days of becoming eligible. Qualifying students would initially have access to in-state tuition at a community college, but would be able to transfer to a fouryear university - with the in-state tuition discount - after two years or completion of 60 credits (equivalent of two years of full-time study). After the bill became law, opponents gathered a sufficient number of signatures to qualify for a veto referendum. In November 2012, Maryland voters upheld the Dream Act by a margin of 59 percent to 41 percent. $^{2}$

The in-state tuition differential in Maryland is substantial. At the time the legislation passed, in-state tuition at the University of Maryland in College Park stood at about \$7,200 a year, compared with $\$ 25,600$ for an out-of-state student (Anderson and Lazo, 2012). Proponents of the Dream Act argued that the number of students who would qualify was small and that the state would benefit from the investment in the education of unauthorized immigrants who arrived in the United States as children. Those who opposed the policy disapproved of the use of public funds to support unauthorized immigrants and claimed that U.S. citizen students would be displaced from slots in the public university system (Anderson and Lazo, 2012). Arguments on both sides have merit according to the cost-benefit framework presented in Table 3.13. Thus, whether the net benefits are positive, negative, or zero requires a comprehensive CBA that takes into account both potential costs and benefits.

\section{CBA Analysis and Findings}

The CBA conducted by Gindling and Mandell $(2012,2015)$ provided an estimate of the number of students who would benefit from the Maryland Dream Act, both in terms of increased high school completion and in terms of higher college attendance and completion. This estimate then formed the basis for estimating the benefits to unauthorized immigrants, as well as the fiscal costs and benefits to government at the county, state, and federal level. ${ }^{3}$ Drawing on research cited in Table 3.12 on the causal effects of making in-state tuition available regardless of immigration status on high school completion and college attendance (e.g., Kaushal, 2008; Flores, 2010; Potochnick, 2011; and Amuedo-Dorantes and Sparber, 2014), the study concluded that an estimated 185 unauthorized immigrant students in each annual 18-year-old cohort would be induced to complete high school because of the Dream Act. An estimated 435 unauthorized immigrants in each annual cohort would attend college and qualify for the in-state tuition rate. Of

\footnotetext{
2 This section draws on Gindling and Mandell (2012, 2015).

${ }^{3}$ Education subsidies in Maryland vary with the level of government: Counties contribute to high school and community college costs; the state contributes to high school, community college, and university costs; and the federal government contributes to high school costs.
} 
that group, 163 would obtain more education compared with the status quo, while the remaining 272 would not complete more schooling but would still benefit from the tuition discount.

With these estimates, the authors calculate net benefits to unauthorized immigrants in the form of the tuition discount for those who attend college and the higher lifetime earnings for those who increase their education (net of schooling costs, forgone earnings while in school, and tax payments on earnings). For the government, the net benefits consist of the higher tax revenue (Medicare taxes, income taxes, sales taxes) associated with higher earnings and the reduction in incarceration costs due to higher educational attainment, less the public education subsidies provided to unauthorized immigrants in high school (for those who are induced to graduate), community college, and university.

In total, the results suggest substantial economic benefit from extending in-state tuition to unauthorized immigrants. The aggregate benefits for each annual cohort (where dollar figures are discounted to 2011 using a discount rate of 3 percent) consist of

- $\$ 41.7$ million in private net benefits from increased after-tax earnings of unauthorized persons, net of increased education costs and forgone earnings

- \$24.6 million in net savings to local, state, and federal governments from higher tax payments and reduced incarceration costs

- $\$ 66.3$ million in total net benefits per annual cohort.

Net benefits are positive for all stakeholders groups - unauthorized immigrants and each level of government.

Various sensitivity analyses (e.g., omitting benefits from reduced crime, alternative estimates of return to schooling, different estimates about induced changes in educational attainment, varied discount rates) show these findings are robust to alternative assumptions. Under some scenarios, however, the net savings at the county level are no longer positive, but they remain greater than zero for the public sector as a whole. Moreover, the Gindling and Mandell $(2012,2015)$ estimates may be viewed as conservative because they do not attempt to value other benefits associated with increased educational attainment (e.g., increased fringe benefits, improved health, reduced use of other social services, intergenerational gains).

\section{Mapping the CBA to the Cost-Benefit Framework}

The cost-benefit framework for in-state tuition policy presented in Table 3.13 included two primary expected impacts: (1) an expected increase in the number of unauthorized immigrants, a finding for which there is little empirical evidence to date of the potential impact; and (2) increased educational attainment of unauthorized immigrants, an impact that was generally supported by the empirical literature. From these two main effects, we traced a number of potential secondary impacts that might affect unauthorized immigrants, authorized immigrants and U.S. citizens, employers, and the public sector. 
Table 4.2 reproduces Table 3.13 with additional row entries for the costs and benefits captured in the Gindling and Mandell $(2012,2015)$ CBA. In cells with red shading, we note that the Maryland Dream Act CBA did not include the costs and benefits that would be associated with an increase in the number of unauthorized immigrants in the state. To their credit, the authors acknowledge that they do not account for possible migration effects; i.e., Maryland becomes a more attractive destination because of the Dream Act. This is justified, in part, by the absence of studies documenting such an effect for in-state tuition policy (as noted in Chapter Three) and by the expectation based on other literature that, if such an effect is realized, the impact is likely to be small. The effect on the bottom-line estimate of net benefits from these omitted potential population effects is uncertain, as each cell indicates that the effects may be

Table 4.2. Assessment of CBA of Maryland Dream Act

\begin{tabular}{|c|c|c|c|c|c|}
\hline & & \multicolumn{4}{|c|}{ Stakeholders } \\
\hline \multicolumn{2}{|c|}{$\begin{array}{l}\text { Potential Main } \\
\text { Impacts }\end{array}$} & $\begin{array}{l}\text { Unauthorized } \\
\text { Immigrants }\end{array}$ & $\begin{array}{c}\text { Authorized } \\
\text { Immigrants and } \\
\text { Native-Born }\end{array}$ & Employers & $\begin{array}{c}\text { State and Local } \\
\text { Government }\end{array}$ \\
\hline \multirow[t]{2}{*}{$\begin{array}{l}\text { Increased } \\
\text { number of } \\
\text { unauthorized } \\
\text { immigrants }\end{array}$} & 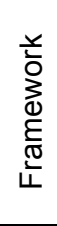 & $\begin{array}{c}+ \text { or - } \\
\text { depending on } \\
\text { difference in skill } \\
\text { mix between those } \\
\text { who arrive and } \\
\text { current residents }\end{array}$ & $\begin{array}{c}+ \text { or - } \\
\text { depending on skill } \\
\text { level and changes } \\
\text { in relative wages }\end{array}$ & $\begin{array}{c}+ \text { or - } \\
\text { depending on skill } \\
\text { mix of employees }\end{array}$ & $\begin{array}{l}+ \text { or - } \\
\text { depending on net } \\
\text { fiscal impact of } \\
\text { unauthorized who } \\
\text { arrive }\end{array}$ \\
\hline & $\begin{array}{l}\vec{\partial} \\
\stackrel{0}{\infty}\end{array}$ & Not included & Not included & Not included & Not included \\
\hline \multirow[t]{3}{*}{$\begin{array}{l}\text { Increased } \\
\text { educational } \\
\text { attainment of } \\
\text { unauthorized } \\
\text { immigrants }\end{array}$} & \multirow[t]{2}{*}{ 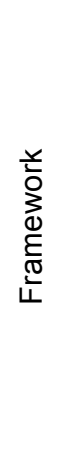 } & \multirow[t]{2}{*}{$\begin{array}{c}+ \\
\text { from lower out-of- } \\
\text { pocket costs of } \\
\text { enrolling in college } \\
\text { and higher human } \\
\text { capital attainment } \\
\text { from attending } \\
\text { college }\end{array}$} & $\begin{array}{c}0 \text { or - } \\
\text { depending on net } \\
\text { increase in human } \\
\text { capital attainment if } \\
\text { access to subsidies } \\
\text { is capped and } \\
\text { spaces are now } \\
\text { freed up }\end{array}$ & \multirow[t]{2}{*}{$\begin{array}{l}+ \text { or - } \\
\text { depending on net } \\
\text { effect on skill mix of } \\
\text { workforce, skill mix } \\
\text { of employees, and } \\
\text { wage structure }\end{array}$} & $\begin{array}{l}\text { - or } 0 \\
\text { for higher } \\
\text { education } \\
\text { subsidies } \\
\text { depending on } \\
\text { change in } \\
\text { subsidized } \\
\text { enrollment }\end{array}$ \\
\hline & & & $\begin{array}{l}+ \text { or - } \\
\text { depending on skill } \\
\text { level and changes } \\
\text { in relative wages }\end{array}$ & & $\begin{array}{c}+ \text { or } 0 \\
\text { depending on net } \\
\text { change in college- } \\
\text { educated }\end{array}$ \\
\hline & $\begin{array}{l}\overrightarrow{0} \\
\stackrel{D}{0}\end{array}$ & $\begin{array}{l}\checkmark \text { Benefit of } \\
\text { discounted } \\
\text { tuition } \\
\checkmark \text { Benefit of } \\
\text { increased } \\
\text { lifetime earnings } \\
\text { from higher } \\
\text { educational } \\
\text { attainment }\end{array}$ & Not included & Not included & $\begin{array}{l}\checkmark \text { Cost of } \\
\text { additional } \\
\text { education } \\
\text { subsidies } \\
\checkmark \text { Benefit of higher } \\
\text { taxes paid } \\
\checkmark \text { Benefit of } \\
\text { reduced } \\
\text { incarceration } \\
\text { costs }\end{array}$ \\
\hline
\end{tabular}

SOURCE: Author's analysis of Gindling and Mandell $(2012,2015)$.

NOTES: + / - / 0 = favorable, unfavorable, and neutral outcome, respectively, from perspective of stakeholder. Green shading indicates data were for accounted in the CBA under review; red shading indicates data were not accounted for. 
favorable or unfavorable depending on the skill mix of the unauthorized immigrants who arrive (or stay) because of the new policy, the corresponding changes in relative wages, and the net fiscal impact of the added unauthorized population.

Green shading in Table 4.2 indicates that Gindling and Mandell (2012, 2015) do account for the effects of increased educational attainment (the second row) for two stakeholder groups: unauthorized immigrants and the public sector. The two potential impacts that are omitted (red shading) represent potential general equilibrium wage effects for authorized immigrants and natives (because of the increased educational attainment), potential crowding out of authorized immigrants and natives if there are limited subsidized higher education slots, and the effects on employers (and employment) because of the changes in relative wages.

With respect to crowding out, Gindling and Mandell $(2012,2015)$ recognize that they do not incorporate this potential impact, i.e., authorized immigrants or U.S. citizens who are not able to access in-state tuition subsidies because of the increased enrollments of unauthorized students. This is justified by the fact that Maryland's Dream Act policy requires spending the first two years at a Maryland community college, a system that has open access admissions (hence, no crowding out). In fact, some unauthorized immigrants who might have started out at a four-year public university without in-state tuition will free up spaces at those institutions if they instead enter a community college to take advantage of the subsidized tuition. Likewise, public universities in Maryland are required to accept all two-year community college transfers who meet minimum requirements (e.g., their average grades), which again should limit crowding out. Moreover, this omission is consistent with findings in the literature of no crowding out of nontargeted students in other states with in-state tuition available regardless of immigration status (see Table 3.12). If crowding out can be assumed to be zero, then, again, the primary omission is the potential general equilibrium effects on the wage structure in the state, with effects on net benefits that may be positive, negative, or zero.

In sum, Gindling and Mandell $(2012,2015)$ provide a rigorous and relatively complete CBA of the Maryland Dream Act. They draw on relevant research on the estimated causal effects of making in-state tuition available regardless of immigration status to qualifying students. To the extent that potential impacts and their associated costs or benefits are omitted, there is either little research evidence to support an estimate or the research suggests that the effects will be small and can safely be ignored.

\section{Assessment of a CBA of California's Proposition 187 Provision Regarding Access to Publicly Funded Health Care}

California voters approved Proposition 187, also known as the Save Our State initiative, in 1994 in response to growing concern about the number of unauthorized immigrants in the state (estimated at more than 1 million) and their costs to state taxpayers (calculated to be $\$ 3$ billion annually) (Margolis, 1994). One of the first state policy initiatives to address unauthorized 
immigration, its key features included prohibiting unauthorized immigrants from accessing nonemergency medical care from publicly funded health care facilities (e.g., at public hospitals), public education (elementary, secondary, and postsecondary), and other state-funded services. The initiative also included requirements for local law enforcement to determine the immigration status of detainees. Upon passage, opponents quickly filed a lawsuit, and the initiative was soon found to be unconstitutional by a federal district court. Under a new governor, the state ended the appeals process, and the law was never enforced.

Those who supported the initiative focused on the costs to the state of providing services to unauthorized immigrants, while opponents raised concerns about discriminatory treatment of unauthorized immigrants - and, potentially, authorized immigrants and U.S. citizens as well. The fiscal analysis by the California Legislative Analyst's Office concluded that the initiative would result in annual savings of $\$ 200$ million for the state because of reduced public-sector costs for services for unauthorized immigrants. Those savings would be at least partially offset by annual administrative costs related to verifying U.S. citizenship status or lawful immigration status. Again, a comprehensive CBA would be one way of assessing the costs and benefits of the policy change as a whole or the net effect of any given component.

\section{CBA Analysis and Findings}

Lu et al. (2000) provide a CBA for one provision of the initiative: the prohibition on providing publicly funded prenatal health care services for unauthorized immigrant women. In the analysis, the researchers first developed estimates of the relationship between access to prenatal care and low birth weight and prematurity. Drawing on data for a cohort of unauthorized immigrants in one public university-based hospital in the state, the estimates showed a fourfold increase in low birth weight associated with having no prenatal care and a more than sevenfold increase in a premature birth. Although not based on impact estimates that control for potential selectivity of who has access to prenatal care, the estimates are consistent with other research showing that, for general populations, prenatal care reduces prematurity and low birth weight, each with attendant health and developmental benefits for the child.

The CBA by Lu et al. (2000) took the payer or public-sector perspective, rather than the societal perspective. For the 10 percent of unauthorized women with no prenatal care, the costs for postnatal care and long-term morbidity were calculated at more than $\$ 5,500$ above the cost of prenatal care. Every dollar eliminated from public prenatal care services was estimated to cost $\$ 3.33$ in additional postnatal care and $\$ 4.63$ in incremental cost accounting for long-term morbidity. Expressed as an aggregate, the $\$ 58$ million in savings from eliminating prenatal care services for unauthorized immigrants would cost the state $\$ 194$ million in additional postnatal care. Accounting for long-term health issues, the aggregate cost in the long run was estimated to be $\$ 211$ million. Sensitivity analyses (e.g., varying the proportion of unauthorized women without access to prenatal care, varying the cost of prenatal care and postnatal care) showed a range of estimated net benefits, from breaking even to net added costs of about $\$ 13,000$ per woman. 


\section{Mapping the CBA to the Cost-Benefit Framework}

Table 3.19 provided a cost-benefit framework to apply when evaluating the costs and benefits of extending access to subsidized prenatal care and child health insurance to unauthorized immigrants. Because Proposition 187 restricted access to prenatal care on the part of unauthorized immigrants, we would expect the impacts to be the opposite sign. In addition, the Lu et al. (2000) CBA of Proposition 187 did not concern changes in access to child health insurance for unauthorized immigrants. Thus, Table 4.3 reproduces Table 3.19 with opposite signs and with the elimination of those impacts associated specifically with access to child health insurance.

Table 4.3. Assessment of CBA of California Proposition 187 Prenatal Care Provisions

\begin{tabular}{|c|c|c|c|c|c|}
\hline \multirow{2}{*}{\multicolumn{2}{|c|}{$\begin{array}{l}\text { Potential Main } \\
\text { Impacts }\end{array}$}} & \multicolumn{4}{|c|}{ Stakeholders } \\
\hline & & $\begin{array}{l}\text { Unauthorized } \\
\text { Immigrants }\end{array}$ & $\begin{array}{c}\text { Authorized } \\
\text { Immigrants and } \\
\text { Native-Born }\end{array}$ & Employers & $\begin{array}{l}\text { State and Local } \\
\text { Government }\end{array}$ \\
\hline \multirow[t]{2}{*}{$\begin{array}{l}\text { Decreased } \\
\text { number of } \\
\text { unauthorized } \\
\text { immigrants }\end{array}$} & 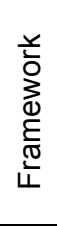 & $\begin{array}{c}+ \text { or }- \\
\text { depending on } \\
\text { difference in skill } \\
\text { mix between those } \\
\text { who leave and } \\
\text { current residents }\end{array}$ & $\begin{array}{c}+ \text { or - } \\
\text { depending on skill } \\
\text { level and changes } \\
\text { in relative wages }\end{array}$ & $\begin{array}{c}+ \text { or } 0 \\
\text { depending on skill } \\
\text { mix of employees }\end{array}$ & $\begin{array}{c}+ \text { or - } \\
\text { depending on net } \\
\text { fiscal impact of } \\
\text { unauthorized who } \\
\text { leave }\end{array}$ \\
\hline & $\frac{\overrightarrow{0}}{\stackrel{0}{n}}$ & Not included & Not included & Not included & Not included \\
\hline \multirow[t]{2}{*}{$\begin{array}{l}\text { Diminished } \\
\text { health status of } \\
\text { unauthorized } \\
\text { immigrant } \\
\text { pregnant women } \\
\text { and children }\end{array}$} & 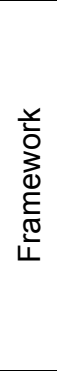 & $\begin{array}{l}- \\
\text { from diminished } \\
\text { health in short term } \\
\text { and longer term }\end{array}$ & $\begin{array}{c}- \\
\text { from diminished } \\
\text { health in short term } \\
\text { and longer term for } \\
\text { U.S. citizen children } \\
\text { born to } \\
\text { unauthorized } \\
\text { immigrant mothers }\end{array}$ & $\begin{array}{c}+ \text { or }- \\
\text { for hospitals and } \\
\text { health care } \\
\text { providers depending } \\
\text { on net health care } \\
\text { spending of } \\
\text { unauthorized who } \\
\text { do not receive } \\
\text { subsidized prenatal } \\
\text { care }\end{array}$ & $\begin{array}{c}+ \text { or }- \\
\text { depending on net } \\
\text { fiscal impact of } \\
\text { unauthorized who } \\
\text { do not receive } \\
\text { subsidized prenatal } \\
\text { care }\end{array}$ \\
\hline & $\frac{\overrightarrow{0}}{\overrightarrow{0}}$ & Not included & Not included & Not included & $\begin{array}{l}\checkmark \text { Savings in } \\
\text { reduced prenatal } \\
\text { care } \\
\checkmark \text { Cost of increased } \\
\text { cost of postnatal } \\
\text { care and long- } \\
\text { term morbidity }\end{array}$ \\
\hline
\end{tabular}

SOURCE: Author's analysis of Lu et al. (2000).

NOTES: $+/-/ 0$ = favorable, unfavorable, and neutral outcome, respectively, from perspective of stakeholder. Green shading indicates data were for accounted in the CBA under review; red shading indicates data were not accounted for.

Table 4.3 indicates two main areas of expected impact from eliminating access to prenatal care services on the part of unauthorized immigrants: a decreased number of unauthorized immigrants in the state because of the loss of public benefits and a diminished health status for 
unauthorized pregnant women and their children who no longer receive prenatal care. In both cases, there was a paucity of literature that estimated the relationship between state-level policy in this area and the expected outcomes (see Table 3.18). Thus, it is not surprising that $\mathrm{Lu}$ et al. (2000) develop their own estimates based on a descriptive analysis.

As mapped in Table 4.3, it is evident that the Lu et al. (2000) study did not include estimates of costs and benefits associated with the first main impact: the effect on migration. Given that the cells in the first row for the four stakeholder groups imply an uncertain net impact, it is not possible to indicate whether the CBA understates or overstates net benefits. In the case of the second main impact on adult and child health, given that $\mathrm{Lu}$ et al. (2000) take the payer perspective, there is no need to account for the private costs and benefits captured for the first three stakeholder groups (unauthorized immigrants, authorized immigrants, and U.S. citizens, as well as employers). Thus, the only green shaded cell in Table 4.3 consists of the net effects for the public sector of the government savings from not providing prenatal care compared with the increased downstream public health care costs associated with poorer health outcomes.

From the payer perspective, the CBA by Lu et al. (2000) captures the main predicted effects from the expected diminished health outcomes. The added costs from the poor health outcomes associated with a lack of prenatal care outweigh the savings from prohibiting publicly subsidized prenatal care. 


\section{Conclusions and Policy Implications}

In the absence of comprehensive federal immigration reform, virtually all states have taken a more active role in the past 15 years in setting policy with respect to unauthorized immigrants. Some states have been dominated by legislation and other policy actions that place greater restrictions on unauthorized immigrants pertaining to employment, education, housing, health care, and other aspects of daily life. These policies targeting unauthorized immigrants include expanding local law enforcement involvement in enforcing federal immigration laws, mandating that employers verify work eligibility, prohibiting access to discounted tuition for otherwise eligible unauthorized immigrants, blocking eligibility for state driver's licenses, and excluding access to publicly subsidized prenatal care and child health insurance. These policies represent forms of both territorial exclusion and social exclusion that have the potential to increase the risk of deportation, reduce the likelihood of employment, lower earnings when employed, and raise living costs, among other consequences. At the same time, other states have taken the opposite course and adopted policies with the reverse intent relative to the status quo, divorcing immigration status from access to in-state tuition, eligibility for state-issued driver's licenses, and access to subsidized health care. Still other states have adopted a mixture of these policies that are restrictive toward unauthorized immigrants in some areas and unrestrictive in others. By our accounting in Chapter Two, all but 11 states have adopted one or more of the policies we examined, with much of the policy change occurring in the past decade.

The goal of this study has been to document the key state-level immigration-related policies and their variation; develop a cost-benefit framework for classifying the potential impacts of specific state-level policies; review the literature to determine whether there is an evidence base that confirms the expected impacts and incorporate the research into the cost-benefit framework; and use the cost-benefit framework to assess the rigor and relevance of existing cost-benefit studies of the fiscal and economic impacts of specific state-level immigration-related policies.

In this final chapter, we first highlight key findings from our analyses and then draw out the implications for policy.

\section{Key Findings}

The analyses presented in Chapters Three and Four produce the following key findings.

\section{State-Level Immigration Policies May Produce Impacts in Multiple Domains}

State-level immigration-related policies are typically motivated by concerns for the size of the unauthorized immigrant population in a state, competition in the labor market between unauthorized immigrants and authorized immigrants and native workers, and the use of public 
services by unauthorized immigrants, among other demographic, economic, and social impacts of unauthorized immigration. Regardless of the type of state-related immigration policywhether omnibus legislation or a more targeted policy change - it is important to recognize that policy impacts may accrue in multiple policy domains.

Indeed, both theoretical predictions and empirical findings indicate that, depending on the policy, impacts may be found in the size of the unauthorized population in the state; the level and distribution of state economic activity; the labor market, in terms of the level of employment and wages, the sectoral composition of employment, and the relative wages across worker subgroups based on skill; primary, secondary, and postsecondary education in terms of enrollment and attainment; law enforcement and the criminal justice system; the social welfare system; population health and utilization of health care; and state and local government taxes and expenditures. One advantage of CBA is that it provides a framework for undertaking a comprehensive assessment of the full range of potential policy impacts and for determining the costs and benefits in aggregate and for specific stakeholders in the public and private sectors.

\section{Some Expected Effects Have a Clear Direction of Impact; Others Are More Uncertain}

When assessing the potential impacts of state-level immigration-related policies, relative to the status quo, some expected effects can be clearly designated as positive, negative, or neutral. In the case of policies that are restrictive toward unauthorized immigrants (e.g., requirements for the use of E-Verify), the first-order effects for the unauthorized immigrant population are typically unfavorable (i.e., costs exceed benefits), and the reverse holds when policies are unrestrictive. For example, when states mandate the use of E-Verify, unauthorized immigrants can be expected to experience decreased employment with the commensurate loss of earnings (see Table 3.9). By comparison, when states make in-state tuition available regardless of immigration status, unauthorized immigrants unambiguously gain from both lower out-of-pocket education costs and higher lifetime earnings when their educational attainment increases (see Table 3.13). Other outcomes, typically second-order effects through changes in labor supply or labor demand, are less certain in terms of their expect net benefits. With the E-Verify example, some unauthorized immigrants may experience net gains if wages increase for lower-skilled workers (because of reduced supply) and if they are able to remain employed through selfemployment or work in a sector that is not covered by the E-Verify requirement. Given these uncertainties in the policy impacts, it is important to undertake empirical research to assess the realized outcomes for unauthorized immigrants and other population groups in states adopting immigration-related policies relative to those that do not.

\section{Expected Effects Often Go Beyond Those for Unauthorized Immigrants to Include Potential Spillover Effects for Other Stakeholders}

Although unauthorized immigrants are often the target of state-level immigration policy, there are theoretical reasons to expect spillover consequences for authorized immigrants and the 
native-born population. This is especially true when policies affect the labor market through changes in labor supply or labor demand. Spillover consequences also may be a consideration in mixed-status families where one or both parents are unauthorized immigrants but some or all of their children are native-born U.S. citizens.

In each of the policy areas we considered, we identified potential impacts for authorized immigrants and natives (including the U.S. citizen children of unauthorized immigrant parents), effects that were often unintended and theoretically ambiguous in terms of their net effect. To the extent that state-level immigration policies also affect state and local governments (or even the federal government), those effects ultimately affect nontargeted populations as taxpayers or recipients of government services. For example, expanding state- and local-level immigrationrelated enforcement may affect authorized immigrants and the native-born if law enforcement costs increase overall or if greater immigration-related enforcement crowds out other law enforcement activity (see Table 3.6).

Such spillover effects have received less attention in the empirical literature, but there is suggestive evidence that nontargeted groups may lose or gain as well. Studies of stricter enforcement of immigration laws at the local level found reduced participation in Medicaid on the part of U.S. citizen children whose parents were likely unauthorized immigrants (see Table 3.5), as well as increased poverty (see Table 3.10). Studies of the impact of mandating E-Verify indicated that naturalized U.S. citizens and native-born populations with low education levels also experienced declines in employment, potentially because of a decline in labor demand (see Table 3.8). On the other hand, studies of states extending in-state tuition to unauthorized immigrants do not indicate that there is crowding out of authorized immigrants or the native-born from higher education (see Table 3.12). The potential for such spillover gains or losses for other population groups is important to consider in any comprehensive accounting of policy impacts.

\section{A Growing Literature Documents the Effects of State-Level Policies, But Important Gaps Remain}

As the volume of state-level immigration-related policies has expanded, there has been growth in the number of research studies that seek to measure the causal effects of the policies. In doing so, researchers can exploit the variation across states and across time in the policy environment to identify impacts that can be interpreted as causal effects. The policies that have received most of the attention by researchers include expanding state- and local-level immigration-related enforcement (see Table 3.5), mandating the use of E-Verify (see Table 3.8), restrictive omnibus legislation (see Table 3.10), and making in-state tuition available regardless of immigration status (see Table 3.12). Policies that have received less attention include making driver's licenses available regardless of immigration status and extending coverage for prenatal care and children's health insurance to low-income immigrants regardless of status. Where research has been conducted, much of the focus has been on labor market outcomes (e.g., employment and 
wages) and, to a lesser extent, population levels and shares. Studies of in-state tuition policy naturally focus on educational outcomes.

Although there is much to be learned from this body of evidence, it is also important to keep in mind some of the limitations. One drawback is that, because the policy changes are relatively recent, most of the studies capture only short-term effects. In the case of restrictive policies, such as an E-Verify mandate, longer-term effects may be attenuated if enforcement of the mandate is limited or if those affected learn how to circumvent the requirement. For unrestrictive policies, such as in-state tuition that is available regardless of immigration status, effects may strengthen with time as more unauthorized immigrants become aware of the policy and respond accordingly. Another consideration is that the effects of any given policy may differ from the estimates available in the literature once more states have adopted the policy or it becomes national policy. Some of the impacts we discussed, such as cross-state migration or labor market effects, arose because there are currently other states where a given policy is not in effect.

\section{Few Formal CBAs of State-Level Immigration Policies Have Been Conducted}

Given that the net effects of the state-level immigration-related policies we examined are often ambiguous, a formal CBA is required to more fully understand the expected net benefits of a given policy for any one stakeholder group or for society as a whole. To date, efforts to conduct a complete accounting of the costs and benefits of these policies through a formal CBA have been relatively rare. Notably, our literature search identified few comprehensive CBAs of the set of state-level immigration-related policies we examine in this study. Numerous analyses calculate the net fiscal or economic impact of immigration in total or unauthorized immigration in particular, but those studies do not provide analyses of specific policy impacts. Other studies that focus on costs or benefits of specific immigration-related policies or bundles of policies (i.e., omnibus legislation) are often designed to support or oppose the policy change, and therefore do not provide a comprehensive, balanced assessment of both costs and benefits to all relevant stakeholders. In many cases, such studies have not taken advantage of empirical estimates of policy impacts from the growing research literature and instead rely on ad hoc assumptions about policy impacts.

\section{Formal CBAs of State-Level Immigration Policies Inform Overall Economic and Fiscal Impacts, as Well as Distributional Consequences}

The two CBAs we reviewed demonstrate the insights that can be gleaned from drawing on research evidence to estimate policy impacts; quantify their dollar costs, benefits, and net benefits in aggregate; and allocate costs and benefits across different stakeholder groups. The framework also helps to identify what is omitted in any given analysis. For example, the two CBAs we reviewed do not capture the potential impacts from cross-state migration induced by the policy change. This reflects, in part, the absence of empirical studies that document these impacts. In addition, the CBA by Lu et al. (2000), by taking a government perspective, omits 
potential private-sector costs and benefits (i.e., for unauthorized immigrants, authorized immigrants and natives, and employers).

Future CBAs can take advantage of the growing literature documenting the impacts of statelevel policies. For our analyses, we focused on studies that used the best available methods to identify the causal effects of the state-level immigration-related policies. Authors of the studies we reviewed also typically explored the robustness of their findings to alternative methods. As this body of research is used to conduct future CBAs, analysts should take care to understand the limitations of any one study or group of studies, such as their generalizability to the policy context being analyzed for the CBA. Even where there is no empirical evidence to support generating a policy impact or the perspective omits some stakeholders, the analysis can still document whether the unmeasured impacts are likely to result in net benefits or net costs and which stakeholder groups will be affected.

\section{Predominance of Certain State Policies May Reflect Underlying Cost-Benefit Calculations}

Although formal CBAs focused on state-level immigration-related policies are relatively sparse, the existing findings suggest policymakers and the public may have been performing such costbenefit calculations implicitly in making immigration policy decisions at the state and local level. For example, the Gindling and Mandell $(2012,2015)$ CBA reviewed in Chapter Four indicates that the Maryland Dream Act, which extends in-state tuition to unauthorized immigrant students who meet several requirements, would pass a cost-benefit test in aggregate and for the public sector under a range of assumptions. As noted in Chapter Two, 60 percent of unauthorized immigrants reside in California, Florida, Illinois, New Jersey, New York, and Texas. Each of these states has extended in-state tuition to unauthorized immigrants, and California and Texas make state financial aid available as well (see Figure 2.2). Overall, 20 states have adopted some form of in-state tuition eligibility for unauthorized immigrants, making it the most prevalent of the unrestrictive policies we examine. This suggests that policymakers and the public in these states have recognized the likely positive economic return and savings to government from investing in the education of all immigrants, regardless of status. At the same time, these states do not uniformly have unrestrictive policies. Most do not yet extend eligibility for driver's licenses to unauthorized immigrants (California and Illinois are the exceptions). Florida and Texas also mandate the use of E-Verify.

\section{Implications for Policy}

Across states and localities, the adoption of immigration-related policies has proceeded apace, especially in the absence of comprehensive federal immigration reform. Often the adoption of the policy changes reviewed in this study has been contentious, whether taken up in the state

legislature or at the ballot box. These debates reflect the fact that the policies reviewed here have 
distributional consequences, with winners and losers both within key stakeholder groups (e.g., subgroups among unauthorized immigrants) and across those groups (e.g., unauthorized immigrants versus authorized immigrants).

The use of a cost-benefit framework, such as the one developed in this study, provides an avenue for developing a more objective, balanced perspective on the expected favorable and unfavorable effects of any given state-level immigration-related policy, the dollar values associated with those outcomes, whether society as a whole benefits from the policy change, and which stakeholder groups are likely to experience net gains versus net losses. The framework can be useful for evaluating policies already in place or for assessing the likely outcomes for a policy change under deliberation. In can also be used as a tool for verifying the comprehensiveness of CBAs of past policies or planned future policies. The framework provides a more transparent mechanism for recognizing that a decisionmaker's perspective (e.g., a narrow government perspective or a broader societal perspective) may influence their position on a given immigration-related policy change.

Our analysis of the research literature points to the role that evaluations of prior policy changes can play in solidifying our understanding of whether state-level immigration-related policies have their intended effects and whether there are any unintended consequences. At the same time, it is important to recognize the limitations of the existing literature that examines the effects of state-level immigration-related policies. For example, using the difference-indifferences approach to infer causal impacts is best accomplished with data covering all 50 states, but such data sources typically do not identify unauthorized immigrants as a group. For this reason, our understanding of policy impacts is often couched in terms of effects for "likely unauthorized immigrants." Although this is a reasonable approximation, it is not ideal and may over- or underestimate the true effects for unauthorized immigrants to the extent that they differ from the authorized immigrant population that is grouped with them as part of the "likely unauthorized" group. Furthermore, the existing research often shows that state-level immigration-related policies do affect key outcomes, but not always in the expected way. This may reflect the extent to which policies are actually enforced or the way individual or employer behavior adapts to the policy environment over time.

The recent pace of state-level policymaking with respect to unauthorized immigrants and immigration suggests this will be an ongoing area for governors, legislators, and other decisionmakers to consider. As noted in Chapter One, policymaking is even shifting to the local level, especially as cities begin to engage immigrants as part of their economic revitalization strategies. The cost-benefit framework developed in this study can readily be adapted to modifications to the policies considered here or to new policies on the horizon. Regardless, a comprehensive cost-benefit framework provides a uniform accounting framework that can be used to evaluate prior research on the impact of state immigration policies and guide future studies. 


\section{References}

Abadie, Alberto, Alexis Diamond, and Jens Hainmueller, "Synthetic Control Methods for Comparative Case Studies: Estimating the Effect of California's Tobacco Control Program," Journal of the American Statistical Association, Vol. 105, 2010, pp. 493-505.

Alexander, Greg R., and Carol C. Korenbrot, "The Role of Prenatal Care in Preventing Low Birth Weight," The Future of Children, Vol. 5, 1995, pp. 103-120.

American Immigration Council and Center for American Progress, The Impact of E-Verify on California's Economy, Washington, D.C., 2011a. As of January 5, 2016:

http://www.immigrationpolicy.org/just-facts/impact-e-verify-california $\% \mathrm{E} 2 \% 80 \% 99 \mathrm{~s}$ economy

—, The Impact of E-Verify on Massachusetts' Economy, Washington, D.C., 2011b. As of January 5, 2016:

http://www.immigrationpolicy.org/just-facts/impact-e-verify-massachusetts $\% \mathrm{E} 2 \% 80 \% 99$ economy

Amuedo-Dorantes, Catalina, Esther Arenas-Arroyo, and Almudena Sevilla-Sanz, "Interior Immigration Enforcement and Childhood Poverty in the United States," working paper, San Diego State University, September 2015.

Amuedo-Dorantes, Catalina, and Cynthia Bansak, “The Labor Market Impact of Mandated Employment Verification Systems," American Economic Review, Vol. 102, No. 3, 2012, pp. 543-548.

—., "Employment Verification Mandates and the Labor Market of Likely Unauthorized and Native Workers," Contemporary Economic Policy, Vol. 32, 2014, pp. 671-680.

Amuedo-Dorantes, Catalina, Cynthia Bansak, and Allan A. Zebedee, "The Impact of Mandated Employment Verification Systems on State-Level Employment by Foreign Affiliates,"

Southern Economic Journal, Vol. 81, No. 4, 2015, pp. 928-946.

Amuedo-Dorantes, Catalina, Xing Jin, and Susan Pozo, "E-Verify and Perceptions of Discrimination Among Hispanic Citizens," working paper, San Diego State University, 2015.

Amuedo-Dorantes, Catalina, and Mary J. Lopez, "Falling Through the Cracks? Grade Retention and School Dropout Among Children of Likely Unauthorized Immigrants," American Economic Review, Vol. 105, No. 5, 2015, pp. 598-603. 
Amuedo-Dorantes, Catalina, and Fernando Lozano, "Interstate Mobility Patterns of Likely Unauthorized Immigrants: Evidence from Arizona," working paper, San Diego State University, 2015a.

— , "On the Effectiveness of SB1070 in Arizona," Economic Inquiry, Vol. 53, 2015b, pp. 335-351.

Amuedo-Dorantes, Catalina, Thitima Puttitanun, and Ana P. Martinez-Donate, "How Do Tougher Immigration Measures Affect Unauthorized Immigrants?” Demography, Vol. 50, No. 3, 2013, pp. 1067-1091.

Amuedo-Dorantes, Catalina, and Chad Sparber, "In-State Tuition for Undocumented Immigrants and Its Impact on College Enrollment, Tuition Costs, Student Financial Aid, and Indebtedness," Regional Science and Urban Economics, Vol. 49, 2014, pp. 11-24.

Anderson, Nick, and Luz Lazo, “Maryland Voters Approve 'Dream Act' Law," Washington Post, November 7, 2012. As of January 5, 2016:

https://www.washingtonpost.com/local/md-politics/md-voters-deciding-on-dream-actlaw/2012/11/06/d539fe66-282f-11e2-bab2-eda299503684_story.html

Appold, Stephen, Randy Capps, Michael Fix, Ying Huang, Rafael Jimeno, James Johnson, John Kasarda, and Kristen Mccabe, A Profile of Immigrants in Arkansas, Little Rock, Ark.:

Winthrop Rockefeller Foundation, January 2013. As of January 5, 2016:

http://www.wrfoundation.org/beyond-grantmaking/profile-of-immigrants-in-arkansas.html

Arvelo, Jason, ““Free’ E-Verify May Cost Small Business \$2.6 Billion,” Insight, Bloomberg Government, January 27, 2011.

Aydemir, Abdurrahman Bekir, and George J. Borjas, "Cross-Country Variation in the Impact of International Migration: Canada, Mexico, and the United States," Journal of the European Economic Association, Vol. 5, 2007, pp. 663-708.

Bianchi, Milo, Paolo Buonanno, and Paolo Pinotti, “Do Immigrants Cause Crime?” Journal of the European Economic Association, Vol. 10, No. 6, 2012, pp. 1318-1347.

Black, Sandra E., Paul J. Devereux, and Kjell G. Salvanes, "From the Cradle to the Labor Market? The Effect of Birth Weight on Adult Outcomes," Quarterly Journal of Economics, Vol. 122, No. 1, 2007, pp. 409-439.

Bohn, Sarah, Magnus Lofstrom, and Steven Raphael, "Did the 2007 Legal Arizona Workers Act Reduce the State's Unauthorized Immigrant Population?" Review of Economics and Statistics, Vol. 96, No. 2, 2014, pp. 258-269.

_ - "Do E-Verify Mandates Improve Labor Market Outcomes of Low-Skilled Native and Legal Immigrant Workers?” Southern Economic Journal, Vol. 81, 2015, pp. 960-979. 
Borjas, George J., Immigration and the American Worker: A Review of the Academic Literature, Washington, D.C.: Center for Immigration Studies, 2013. As of January 5, 2016:

http://cis.org/sites/cis.org/files/borjas-economics.pdf

—, Immigration Economics, Cambridge, Mass.: Harvard University Press, 2014.

Bozick, Robert, and Trey Miller, "In-State College Tuition Policies for Undocumented

Immigrants: Implications for High School Enrollment Among Non-Citizen Mexican Youth," Population Research and Policy Review, Vol. 33, No. 1, 2014, pp. 13-30.

Bozick, Robert, Trey Miller, and Matheu Kaneshiro, "Non-Citizen Mexican Youth in Higher Education: A Closer Look at the Relationship Between State Tuition Policies and College Enrollment," International Migration Review, 2015. doi: 10.1111/imre.12167.

Bratsberg, Bernt, Oddbjørn Raaum, Marianne Røed and Pål Schøne, "Immigration Wage Impacts by Origin," Scandinavian Journal of Economics, Vol. 116, No. 2, 2014, pp. 356-393.

Brown, Anna, and Eileen Patten, Statistical Portrait of the Foreign-Born Population in the United States, 2012, Washington, D.C.: Pew Research Center, April 2014. As of January 5, 2016:

http://www.pewhispanic.org/2014/04/29/statistical-portrait-of-the-foreign-born-populationin-the-united-states-2012/

Bryant, Phil, The Impact of Illegal Immigration on Mississippi: Costs and Population Trends, Jackson, Miss.: Office of the State Auditor, 2006.

Butcher, Kristin F., and Anne Morrison Piehl, "Cross-City Evidence on the Relationship Between Immigration and Crime," Journal of Policy Analysis and Management, Vol. 17, No. 3, 1998, pp. 457-493.

—, "Why Are Immigrants' Incarceration Rates So Low? Evidence on Selective Immigration, Deterrence, and Deportation," Working Paper No. 13229, Cambridge, Mass.: National Bureau of Economic Research, 2007. As of January 5, 2016:

http://www.nber.org/papers/w13229

Cáceres, Mauricio, and Kenneth P. Jameson, "The Effects on Insurance Costs of Restricting Undocumented Immigrants' Access to Driver Licenses,” Southern Economic Journal, Vol. 81, 2015, pp. 907-927.

Capps, Randy, Marc R. Rosenblum, Cristina Rodriquez, and Muzaffar Chishti, Delegation and Divergence: A Study of 287(g) State and Local Immigration Enforcement, Washington, D.C.: Migration Policy Institute, 2011.

Card, David, "Immigration and Inequality," American Economic Review, Vol. 99, No. 2, 2009, pp. 1-21. 
Case, Anne, and Christina Paxson, "Stature and Status: Height, Ability, and Labor Market Outcomes," Journal of Political Economy, Vol. 116, No. 3, 2008, pp. 499-532.

Chalfin, Aaron, "What Is the Contribution of Mexican Immigration to U.S. Crime Rates? Evidence from Rainfall Shocks in Mexico," American Law and Economics Review, Vol. 16, No. 1, 2014, pp. 220-268.

Chin, Aimee, and Chinhui Juhn, "Does Reducing College Costs Improve Educational Outcomes for Undocumented Immigrants? Evidence from State Laws Permitting Undocumented Immigrants to Pay In-State Tuition at State Colleges and Universities," Working Paper No. 15932, Cambridge, Mass.: National Bureau of Economic Research, 2010. As of January 5, 2016: http://www.nber.org/papers/w15932

Cohodes, Sarah, Daniel Grossman, Samuel Kleiner, and Michael F. Lovenheim, "The Effect of Child Health Insurance Access on Schooling: Evidence from Public Insurance Expansions," Working Paper No. 20178, Cambridge, Mass.: National Bureau of Economic Research, 2014. As of January 5, 2016:

http://www.nber.org/papers/w20178

Commission to Study the Impact of Immigrants in Maryland, The Impact of Immigrants in Maryland: Final Report, College Park, Md.: University of Maryland, 2012.

Congressional Budget Office, The Impact of Unauthorized Immigrants on the Budgets of State and Local Governments, Washington, D.C., 2007. As of January 5, 2016: http://www.cbo.gov/publication/41645

Currie, Janet, and Jonathan Gruber, "Health Insurance Eligibility, Utilization of Medical Care, and Child Health," Quarterly Journal of Economics, Vol. 111, 1996a, pp. 431-466.

_- "Saving Babies: The Efficacy and Cost of Recent Changes in Medicaid Eligibility of Pregnant Women," Journal of Political Economy, Vol. 104, 1996b, pp. 1263-1296.

Dickson, Lisa, and Matea Pender, "Do In-State Tuition Benefits Affect the Enrollment of NonCitizens? Evidence from Universities in Texas," Economics of Education Review, Vol. 37, 2013, pp. 126-137.

Ehresman, Ruth, Undocumented Workers: Impact on Missouri's Economy, St. Louis, Mo.: The Missouri Budget Project, 2006. As of January 5, 2016:

http://www.mobudget.org/files/Undocumented $\% 20$ Workers $\% 20 I m p a c t \% 20$ on $\% 20$ Missouri \%20Economy\%20June\%2006.pdf

Fairley, Elena, and Rich Jones, Colorado's Undocumented Immigrants: What They Pay, What They Cost in Taxes, Denver, Colo.: The Bell Policy Center, 2011. As of January 5, 2016: http://bellpolicy.org/sites/default/files/ImmigrationTaxesCost2011_1.pdf 
Fennelly, Katherine, and Anne Huart, The Economic Impact of Immigrants in Minnesota, Minneapolis, Minn.: Northwest Area Foundation and Hubert H. Humphrey Institute of Public Affairs, University of Minnesota, 2010.

Flores, Stella M., "State Dream Acts: The Effect of In-State Resident Tuition Policies and Undocumented Latino Students," The Review of Higher Education, Vol. 33, No. 2, 2010, pp. 239-283.

Friedberg, Rachel, and Jennifer Hunt, "The Economic Impact of Immigrants on Host Country Wages, Employment, and Growth," Journal of Economic Perspectives, Vol. 9, No. 2, Spring 1995, pp. 23-44.

Gambetta, Ricardo, and Zevile Gedrimaite, Municipal Innovations in Immigrant Integration: 20 Cities, 20 Good Practices, Washington, D.C.: National League of Cities, 2014. As of January 5, 2016:

http://www.nlc.org/Documents/Find\%20City\%20Solutions/Research\%20Innovation/Immigr ant\%20Integration/municipal-innovations-immigrant-integration-20-cities-sep10.pdf

Gans, Judith, Immigrants in Arizona: Fiscal and Economic Impacts, Tucson, Ariz.: The University of Arizona, June 2008. As of January 5, 2016: http://udallcenter.arizona.edu/immigration/publications/impactofimmigrants08.pdf

Gardner, Matthew, Sebastian Johnson, and Meg Wiehe, Undocumented Immigrant's State and Local Tax Contributions, Washington, D.C.: Institute on Taxation and Economic Policy, 2015. As of January 5, 2016:

http://www.itep.org/pdf/undocumentedtaxes2015.pdf

General Services Agency, Regulatory Impact Analysis: Employment Eligibility Verification, Washington, D.C., 2008. As of January 5, 2016:

http://mercatus.org/sites/default/files/publication/FAR\%20RIA\%209000AK91.doc

Gindling, T. H., and Marvin Mandell, Private and Government Fiscal Costs and Benefits of the Maryland Dream Act, working paper, Baltimore: Maryland Institute for Policy Analysis and Research, 2012.

—_ Private and Government Fiscal Costs and Benefits of the Maryland Dream Act, policy brief, Baltimore: Maryland Institute for Policy Analysis and Research, 2015.

Good, Michael, "Do Immigrant Outflows Lead to Native Inflows? An Empirical Analysis of the Migratory Responses to U.S. State Immigration Legislation," Applied Economics, Vol. 45, 2013, pp. 4275-4297.

Goodman-Bacon, Andrew, "Public Insurance and Mortality: Evidence from Medicaid Implementation," working paper, 2015. As of January 5, 2016:

http://www-personal.umich.edu/ ajgb/medicaid_ajgb.pdf 
Gramlich, Edward M., A Guide to Benefit-Cost Analysis, Second Edition, Long Grove, Ill.: Waveland Press, 1990.

Helmcamp, Leslie, and Rachel Cooper, Maximizing Access to College for Immigrant Children Builds the Texas Economy, Austin, Tex.: Center for Public Policy Priorities, 2013. As of January 5, 2016:

http://forabettertexas.org/images/2013_01_24_PP_ImmigrantInStateTuition.pdf

Hoekstra, Mark, and Sandra Orozco-Aleman, "Illegal Immigration, State Law, and Deterrence," Working Paper No. 20801, Cambridge, Mass.: National Bureau of Economic Research, 2014. As of January 5, 2016:

http://www.nber.org/papers/w20801

ICE-See U.S. Immigration and Customs Enforcement.

Institute of Medicine, America's Uninsured Crisis: Consequences for Health and Health Care, Washington, D.C.: The National Academies Press, 2009.

Johnston, Allison, and Ann Morse, E-Verify, Washington, D.C.: National Conference of State Legislatures, December 2012. As of January 5, 2016:

http://www.ncsl.org/research/immigration/everify-faq.aspx

Karoly, Lynn A., "Toward Standardization of Benefit-Cost Analyses of Early Childhood Interventions," Journal of Benefit-Cost Analysis, Vol. 3, No. 1, Article 4, 2012.

Kaushal, Neeraj, "In-State Tuition for the Undocumented: Education Effects on Mexican Young Adults," Journal of Policy Analysis and Management, Vol. 27, 2008, pp. 771-92.

Keaton, Elise, Marija Weeden, Matt Sundeen, and Jim Jacobs, The Tuition Equity Effect:

Measuring the Impact of Providing In-State Tuition Rates for Colorado's Undocumented High School Graduates, Denver, Colo.: Center for Policy Entrepreneurship, 2008.

Kerr, Juliana, Paul McDaniel, and Melissa Guinan, Reimagining the Midwest: Immigration Initiatives and the Capacity of Local Leadership, Chicago, Ill.: The Chicago Council on Global Affairs and the American Immigration Council, September 2014. As of January 5, 2016:

http://www.immigrationpolicy.org/sites/default/files/docs/reimagining_the_midwest_report_ 2014.pdf

Koohi, Shiva, "College Prospects and Risky Behavior Among Mexican Immigrant Youth: The Effect of In-State Tuition Policies," working paper, 2013.

Korenbrot, Carol C., Alycia Steinberg, Catherine Bender, and Sydne Newberry, "Preconception Care: A Systematic Review," Maternal and Child Health Journal, Vol. 6, 2002, pp. 75-88. 
Kostandini, Genti, Elton Mykerezi, and Cesar Escalante, "The Impact of Immigration Enforcement on the Farming Sector," American Journal of Agricultural Economics, 2013, pp. 1-21.

Kuiper, Heather, Gary A. Richwald, Harlan Rotblatt, and Steven Asch, "The Communicable Disease Impact of Eliminating Publicly Funded Prenatal Care for Undocumented Immigrants," Maternal and Child Health Journal, Vol. 3, No. 1, 1999, pp. 39-52.

Lam, Chau, and Ann Morse, U.S. Supreme Court Rules on Arizona's Immigration Enforcement Law, Washington, D.C.: National Conference of State Legislatures, June 2012. As of January 5, 2016:

http://www.ncsl.org/research/immigration/us-supreme-court-rules-on-arizona-immigrationlaws.aspx\#Omnibus_Legislation

Lee, Matthew T., Ramiro Martinez, Jr., and Richard Rosenfeld, "Does Immigration Increase Homicide?” Sociological Quarterly, Vol. 42, No. 4, 2001, pp. 559-580.

Leerkes, Arjen, James D. Bachmeier, and Mark A. Leach, "When the Border Is 'Everywhere': State-Level Variation in Migration Control and Changing Settlement Patterns of the Unauthorized Immigrant Population in the United States," International Migration Review, Vol. 47, No. 4, 2013, pp. 910-943.

Levine, Phillip B., and Diane Schanzenbach, "The Impact of Children's Public Health Insurance Expansions on Educational Outcomes," in David Cutler, Alan Garber, and Dana Goldman, eds., Frontiers in Health Policy Research, Vol. 12, Berkeley, Calif.: Berkeley Electronic Press, 2009.

Lofstrom, Magnus, Sarah Bohn, and Steven Raphael, Lessons from the 2007 Legal Arizona Workers Act, San Francisco, Calif.: Public Policy Institute of California, 2011. As of January 5, 2016:

http://www.ppic.org/content/pubs/report/R_311MLR.pdf

Longhi, Simonetta, Peter Nijkamp, and Jacques Poot, "A Meta-Analytic Assessment of the Effect of Immigration on Wages," Journal of Economic Surveys, Vol. 19, No. 3, 2005, pp. $451-477$.

Lu, Michael C., Yvonne G. Lin, Noelani M. Prietto, and Thomas J. Garite, "Elimination of Public Funding of Prenatal Care for Undocumented Immigrants in California: A Cost/Benefit Analysis," American Journal of Obstetrics and Gynecology, Vol. 182, No. 1, 2000, pp. 233-239.

Margolis, Jeffrey R., "Closing the Doors to the Land of Opportunity: The Constitutional Controversy Surrounding Proposition 187," The University of Miami Inter-American Law Review, Vol. 26, No. 2, 1994/1995, pp. 368-369. 
Mathema, Silva, Providing Identification to Unauthorized Immigrants: The State and Local Landscape of Identification for Unauthorized Immigrants, Washington, D.C.: Center for American Progress, 2015. As of January 5, 2016:

https://cdn.americanprogress.org/wp-content/uploads/2015/11/23122616/ProvidingIDs1.pdf

Mendoza, Gilberto, States Offering Driver's Licenses to Immigrants, Washington, D.C.: National Conference of State Legislatures, July 2015. As of January 5, 2016:

http://www.ncsl.org/research/immigration/states-offering-driver-s-licenses-toimmigrants.aspx

Mendoza, Gilberto, and Mathieu Ostrander, State E-Verify Action, Washington, D.C.: National Conference of State Legislatures, August 2015. As of January 5, 2016: http://www.ncsl.org/research/immigration/state-e-verify-action.aspx

Mendoza, Gilberto, and Noor Shaikh, Tuition Benefits for Immigrants, Washington, D.C.: National Conference of State Legislatures, July 2015. As of January 5, 2016: http://www.ncsl.org/research/immigration/tuition-benefits-for-immigrants.aspx

Meyer, Bruce D., and Laura R. Wherry, "Saving Teens: Using a Policy Discontinuity to Estimate the Effects of Medicaid Eligibility," Working Paper No. 18309, Cambridge, Mass.: National Bureau of Economic Research, 2012. As of January 5, 2016: http://www.nber.org/papers/w18309

Miles, Thomas J., and Adam B. Cox, "Does Immigration Enforcement Reduce Crime? Evidence from 'Secure Communities,'”' Journal of Law and Economics, Vol. 57, No. 4, 2014, pp. 937-973.

Miller, Sarah, and Laura R. Wherry, "The Long-Term Health Effects of Early Life Medicaid Coverage," Ann Arbor, Mich.: University of Michigan Working Paper, 2015. As of January 5, 2016: http://papers.ssrn.com/sol3/papers.cfm?abstract_id=2466691

Morse, Ann, Arizona's Immigration Enforcement Laws, Washington, D.C.: National Conference of State Legislatures, July 2011. As of January 5, 2016:

http://www.ncsl.org/research/immigration/in-state-tuition-and-unauthorized-immigrants.aspx

- State Actions Regarding E-Verify, Washington, D.C.: National Conference of State Legislatures, 2012. As of January 5, 2016:

http://www.ncsl.org/documents/immig/StateActions_Everify.pdf , In-State Tuition and Unauthorized Immigrant Students, Washington, D.C.: National Conference of State Legislatures, February 2014. As of January 5, 2016:

http://www.ncsl.org/research/immigration/analysis-of-arizonas-immigration-law.aspx 
Morse, Ann, Allison Johnston, Hillary Heisel, April Carter, Marie Lawrence, and Joy Segreto, State Omnibus Immigration Legislation and Legal Challenges, Washington, D.C.: National Conference of State Legislatures, August 2012. As of January 5, 2016:

http://www.ncsl.org/research/immigration/omnibus-immigration-legislation.aspx

Morse, Ann, Gilberto Soria Mendoza, Leila Malow, and Hannah Weigle, 2015 Immigration Report, Washington, D.C.: National Conference of State Legislatures, August 2015. As of January 5, 2016:

http://www.ncsl.org/research/immigration/2015-immigration-report.aspx

National Conference of State Legislatures, Immigration Enactments Database, Washington, D.C., 2015a. As of January 5, 2016: http://www.ncsl.org/research/immigration/immigration-laws-database.aspx

— State Laws Related to Immigration and Immigrants, Washington, D.C., 2015b. As of January 5, 2016:

http://www.ncsl.org/research/immigration/state-laws-related-to-immigration-andimmigrants.aspx

National Immigration Law Center, E-Verify: The Impact of Its Mandatory Use on Louisiana Workers and Business, Higher Education, Worker's Rights, and Community Policing, Washington, D.C., 2011. As of January 5, 2016:

http://www.nilc.org/document.html?id=264

—_ Inclusive Policies Advance Dramatically in the States: Immigrants' Access to Driver's Licenses, Higher Education, Workers' Rights, and Community Policing, Washington, D.C., 2013. As of January 5, 2016:

http://www.nilc.org/document.html?id=963

— The Consequences of Being Uninsured, Washington, D.C., 2014. As of January 5, 2016: https://www.nilc.org/document.html?id=1136

—_ Frequently Asked Questions: The Obama Administration's Deferred Action for Childhood Arrivals (DACA), Washington, D.C., August 2015a. As of January 5, 2016: https://www.nilc.org/FAQdeferredactionyouth.html

— - Guide to Immigrant Eligibility for Federal Programs: Medical Assistance Programs for Immigrants in Various States, Washington, D.C., 2015b. As of January 5, 2016:

http://www.nilc.org/guideupdate.html

NCSL—See National Conference of State Legislators. 
New Mexico Fiscal Policy Project, Undocumented Immigrants in New Mexico: State Tax Contributions and Fiscal Concerns, Albuquerque, N.M.: New Mexico Voices for Children, 2006.

Newman, Mark J., and Aimee Clark Todd, Survey of State and Federal Laws That Require Employers to Participate in E-Verify, Atlanta, Ga.: Troutman Sanders, January 2013. As of January 5, 2016:

http://www.troutmansanders.com/files/upload/Survey_Employers_to_Participate_EVerify.pdf

NILC_-See National Immigration Law Center.

Norwrasteh, Alex, and Jim Harper, Checking E-Verify: The Costs and Consequences of a National Worker Screening Mandate, Washington, D.C.: CATO Institute, 2015. As of January 5, 2016: http://object.cato.org/sites/cato.org/files/pubs/pdf/pa775_1.pdf

Okkerse, L., "How to Measure Labour Market Effects of Immigration: A Review," Journal of Economic Surveys, Vol. 22, No. 1, 2008, pp. 1-30.

O’Neil, Kevin, “Immigration Enforcement by Local Police Under 287(g) and Growth of Unauthorized Immigrant and Other Populations," University of Cape Town Working Paper, 2013.

Orrenius, Pia M., and Madeline Zavodny, "The Effects of Tougher Enforcement on the Job Prospects of Recent Latin American Immigrants," Journal of Policy Analysis and Management, Vol. 28, No. 2, 2009, pp. 239-257.

_- "The Impact of E-Verify Mandates on Labor Market Outcomes," Southern Economic Journal, Vol., 81, 2015, pp. 947-959.

Ottaviano, Gianmarco, and Peri Giovanni, "Rethinking the Effect of Immigration on Wages," Journal of the European Economic Association, Vol. 10, 2012, pp. 152-197.

Parrado, Emilio A., "Immigration Enforcement Policies, the Economic Recession, and the Size of Local Mexican Immigrant Populations," The Annals of the American Academy of Political and Social Science, Vol. 641, No. 1, 2012, pp. 16-37.

Passel, Jeffrey, and D'Vera Cohn, Unauthorized Immigrant Totals Rise in 7 States, Fall in 14, Washington, D.C.: Pew Research Center, November 2014. As of January 5, 2016: http://www.pewhispanic.org/2014/11/18/unauthorized-immigrant-totals-rise-in-7-states-fallin-14/ 
Passel, Jeffrey, D’Vera Cohn, Jens Manuel Krogstad, and Ana Gonzalez-Barrera, As Growth Stalls, Unauthorized Immigrant Population Becomes More Settled, Washington, D.C.: Pew Research Center, September 2014. As of January 5, 2016:

http://www.pewhispanic.org/2014/09/03/as-growth-stalls-unauthorized-immigrantpopulation-becomes-more-settled/

Pearson, Beth, and Michael F. Sheehan, Undocumented Immigrants in Iowa: Estimated Tax Contributions and Fiscal Impact, Mount Vernon, Iowa: The Iowa Policy Project, 2007.

Peréz, Zenen Jaimes, Removing Barriers to Higher Education for Undocumented Students, Washington, D.C.: Center for American Progress, 2014. As of January 5, 2016: https://cdn.americanprogress.org/wp-content/uploads/2014/12/UndocHigherEd-report2.pdf

Perryman Group (The), An Analysis of the Economic Impact of Undocumented Workers on Business Activity in the U.S. with Estimated Effects by State and by Industry, Waco, Texas, 2008.

Personal Responsibility and Work Opportunity Reconciliation Act, Public Law 104-193, 1996.

Pew Charitable Trusts, “Immigration Enforcement Within the Nation's Borders," Washington, D.C., 2014a. As of January 5, 2016:

http://www.pewtrusts.org/en/research-and-analysis/issue-briefs/2014/07/immigrationenforcement-within-the-nations-borders

- Mapping Public Benefits for Immigrants in the States, Washington, D.C., 2014b. As of January 5, 2016:

http://www.pewtrusts.org/en/research-and-analysis/issue-briefs/2014/09/mapping-publicbenefits-for-immigrants-in-the-states

- Deciding Who Drives: State Choices Surrounding Unauthorized Immigrants and Driver's Licenses, Washington, D.C., 2015. As of January 5, 2016:

http://www-aws.pewtrusts.org/en/research-and-analysis/reports/2015/08/deciding-who-drives

Pham, Huyen, and Pham Hoang Van, "Economic Impact of Local Immigration Regulation: An Empirical Analysis," Cardoza Law Review, Vol. 32, 2010, pp. 485-518.

Potochnick, Stephanie, "How States Can Reduce the Dropout Rate for Undocumented Immigrant Youth: The Effects of In-State Resident Tuition Policies," Social Science Research, Vol. 45, 2014, pp. 18-32.

Raphael, Steven, and Lucas Ronconi, “The Labor Market Impact of State-Level Immigration Legislation Targeted at Unauthorized Immigrants," working paper, Berkeley, Calif.: University of California, Berkeley, 2009. 
Reid, Lesley W., Harold E. Weiss, Robert M. Adelman, and Charles Jaret, "The ImmigrationCrime Relationship: Evidence Across U.S. Metropolitan Areas," Social Science Research, Vol. 34, No. 4, 2005, pp. 757-780.

Rosenblum, Marc R., E-Verify: Strengths, Weaknesses, and Proposals for Reform, Washington, D.C.: Migration Policy Institute, 2011.

Rossin-Slater, Maya, "Promoting Health in Early Childhood," The Future of Children, Vol. 25, 2015, pp. 103-120.

Sánchez, Gonzalo, "The Response of the Hispanic Noncitizen Population to Anti-Illegal Immigration Legislation: The Case of Arizona SB 1070," working paper, 2015. As of January 5, 2016:

http://econweb.tamu.edu/gsanchez/immigration.

Saunders, Jessica, Nelson Lim, and Don Prosnitz, Enforcing Immigration Law at the State and Local Levels: A Public Policy Dilemma, Santa Monica, Calif.: RAND Corporation, OP-273, 2010. As of January 5, 2016:

http://www.rand.org/pubs/occasional_papers/OP273.html

Smith, James P., and Barry Edmonston, eds., The New Americans: Economic, Demographic, and Fiscal Effects of Immigration, Washington, D.C.: National Academy Press, 1997.

Steinhardt, Max Friedrich, "The Wage Impact of Immigration in Germany: New Evidence for Skill Groups and Occupations," Hamburg Institute of International Economics Research Paper No. 1-23, 2009.

Strayhorn, Carole Keeton, Undocumented Immigrants in Texas: A Financial Analysis of the Impact to the State Budget and Economy, Austin, Tex.: Office of the Texas Comptroller, 2006. As of January 5, 2016:

http://www.cpa.state.tx.us/specialrpt/undocumented/

Teigen, Anne, and Ann Morse, Driver's Licenses for Immigrants, Washington, D.C.: National Conference of State Legislatures, August 2013. As of January 5, 2016:

http://www.ncsl.org/research/transportation/drivers-licenses-for-immigrants.aspx

U.S. Code, Title 8, Aliens And Nationality, Chapter 12, Immigration And Nationality, Subchapter II, Immigration, Part IX, Miscellaneous, Section 1357, Powers of Immigration Officers and Employees, 2005.

U.S. Code, Title 42, Public Health and Welfare, Chapter 7, Social Security, Subchapter XVIII, Health Insurance For Aged And Disabled, Part E - Miscellaneous Provisions, Section 1395dd, Examination and Treatment for Emergency Medical Conditions and Women in Labor, 1986. 
U.S. Immigration and Customs Enforcement, Delegation of Immigration Authority Section 287(g) Immigration and Nationality Act, Washington, D.C.: Author, undated. As of October 1, 2015:

https://www.ice.gov/factsheets/287g\#wcm-survey-target-id

Varsanyi, Monica W., ed., Taking Local Control: Immigration Policy Activism in U.S. Cities and States, Palo Alto, Calif.: Stanford University Press, 2010.

Wadsworth, Tim, "Is Immigration Responsible for the Crime Drop? An Assessment of the Influence of Immigration on Changes in Violent Crime Between 1990 and 2000," Social Science Quarterly, Vol. 91, No. 2, 2010, pp. 531-553.

Waslin, Michele, "Immigration Enforcement by State and Local Police: The Impact on the Enforcers and Their Communities," in Monica W. Varsanyi, ed., Taking Local Control: Immigration Policy Activism in U.S. Cities and States, Palo Alto, Calif.: Stanford University Press, 2010, pp. 97-114.

—, States and Localities Seek Greater Role in Immigration Policy, Washington, D.C.: Pew Charitable Trusts, March 25, 2015. As of January 5, 2016:

http://www.pewtrusts.org/en/research-and-analysis/blogs/stateline/2015/3/25/states-andlocalities-seek-greater-role-in-immigration-policy

Watson, Tara, "Enforcement and Immigrant Location Choice," Working Paper No. 19626, Cambridge, Mass.: National Bureau of Economic Research, 2013. As of January 5, 2016: http://www.nber.org/papers/w19626

_ Participation," American Economic Journal: Economic Policy, Vol. 6, No. 3, 2014, pp. 313-338.

Zerbe, Richard O., Jr., and Allen S. Bellas, A Primer for Benefit-Cost Analysis, Cheltenham, UK: Edward Elgar Publishing, 2006. 